\title{
Effect of Biomedical Materials in the Implementation of a Long and Healthy Life Policy
}

\author{
Leszek A. Dobrzański ${ }^{1, *(\mathbb{D}}$, Anna D. Dobrzańska-Danikiewicz ${ }^{2}$ and Lech B. Dobrzański ${ }^{1}$ (i) \\ 1 Medical and Dental Engineering Centre for Research, Design and Production ASKLEPIOS, \\ 12/1 Jan III Sobieski Street, 44-100 Gliwice, Poland; dobrzanski@centrumasklepios.pl \\ 2 Department of Mechanical Engineering, University of Zielona Góra, 4 Prof. Z. Szafrana St., \\ 65-516 Zielona Góra, Poland; anna.dobrzanska.danikiewicz@gmail.com \\ * Correspondence: leszek.dobrzanski@centrumasklepios.pl
}

Citation: Dobrzański, L.A.;

Dobrzańska-Danikiewicz, A.D.;

Dobrzański, L.B. Effect of Biomedical Materials in the Implementation of a Long and Healthy Life Policy. Processes 2021, 9, 865. https://doi.org/ $10.3390 /$ pr9050865

Academic Editor: Selestina Gorgieva

Received: 23 March 2021

Accepted: 12 May 2021

Published: 14 May 2021

Publisher's Note: MDPI stays neutral with regard to jurisdictional claims in published maps and institutional affiliations.

Copyright: (c) 2021 by the authors. Licensee MDPI, Basel, Switzerland. This article is an open access article distributed under the terms and conditions of the Creative Commons Attribution (CC BY) license (https:/ / creativecommons.org/licenses/by/ $4.0 /)$.

\begin{abstract}
This paper is divided into seven main parts. Its purpose is to review the literature to demonstrate the importance of developing bioengineering and global production of biomaterials to care for the level of healthcare in the world. First, the general description of health as a universal human value and assumptions of a long and healthy life policy is presented. The ethical aspects of the mission of medical doctors and dentists were emphasized. The coronavirus, COVID-19, pandemic has had a significant impact on health issues, determining the world's health situation. The scope of the diseases is given, and specific methods of their prevention are discussed. The next part focuses on bioengineering issues, mainly medical engineering and dental engineering, and the need for doctors to use technical solutions supporting medicine and dentistry, taking into account the current stage Industry 4.0 of the industrial revolution. The concept of Dentistry 4.0 was generally presented, and a general Bioengineering 4.0 approach was suggested. The basics of production management and the quality loop of the product life cycle were analyzed. The general classification of medical devices and biomedical materials necessary for their production was presented. The paper contains an analysis of the synthesis and characterization of biomedical materials supporting medicine and dentistry, emphasizing additive manufacturing methods. Numerous examples of clinical applications supported considerations regarding biomedical materials. The economic conditions for implementing various biomedical materials groups were supported by forecasts for developing global markets for biomaterials, regenerative medicine, and tissue engineering. In the seventh part, recapitulation and final remarks against the background of historical retrospection, it was emphasized that the technological processes of production and processing of biomedical materials and the systematic increase in their global production are a determinant of the implementation of a long and healthy policy.
\end{abstract}

Keywords: health; well-being; long and healthy life policy; medicine; dentistry; medical ethics; COVID-19 pandemic; bioengineering; medical engineering; dental engineering; biomedical materials; Industry 4.0; Dentistry 4.0; Bioengineering 4.0; engineers' ethics

\section{Introduction}

Since the dawn of time, health has been an inalienable and unquestionable human value. Doctors and philosophers have been dealing with the definition of health, diseases, and various disabilities and differences from normality in this area also for many millennia. It turns out, however, that defining these concepts is still difficult to define, although it may seem that they are intuitively close to every human being. Caring for health, from everyday elementary hygiene, through treatments aimed at maintaining physical condition, wide-ranging preventive actions to therapeutic treatments using natural or synthetic pharmacological agents, and decisive interventions in surgical and prosthetic procedures is a normal practice and involves billions of people in the world. Moreover, it is 
commonly known that the scope of officially organized medical care is strongly dependent on the organization's level of society and resources of the state budgets. It is the main reason for the differences in the standard of health care in different countries. Affluent countries are trying to reach many citizens with this care, and health care can be considered common there. Usually, this medical care is, to a large extent, supported, if necessary, from the citizens' own funds. The situation is completely different in economically underdeveloped countries, and political systems are far from liberal democracy. In such countries, medical care does not reach the majority of citizens, or hardly at all. Although the right to health is one of the basic human rights, the level of access to exercising this right is highly diversified depending on the geographic location. The level of health care may vary by several dozen or even several hundred times. It, of course, is closely related to well-being, which is also very diverse. This situation is of particular importance in the era of a severe global pandemic on the transmission of the SARS-CoV-2 coronavirus. The safety of patients and, above all, the safety of medical staff poses new challenges.

The modern level of medicine and dentistry, as its special area, is currently closely related to the development of numerous technical means and medical devices, which became possible thanks to the dynamic development of bioengineering along with medical, dental, and tissue engineering regenerative medicine and cell therapies. Both diagnostics and complex interventional procedures require very advanced medical devices. The development of these areas of knowledge, usually engineering and technical, is now a strong determinant of the development of medicine and medical science in general. Devices of this type are subject to all the industrial development rules; therefore, it is not surprising that these areas reach the Industry 4.0 stage. It is a necessity on the one hand and a challenge on the other. The development of the industry is based on the development of production, which, in turn, cannot exist without the use of engineering materials. In medical and dental devices, a very specific set of properties of the materials used is required, especially biocompatibility and ensuring the absence of adverse interactions with living tissues of the human body, and this group of materials is called biomedical materials or simply biomaterials. It is easy to demonstrate the dependence of the development of this group of materials and related global markets with the level of care for the level of healthcare.

The aim of this very extensive review of the literature is to analyze the importance of bioengineering in the context of the Industry 4.0 stage of the industrial revolution and the development of global production of biomaterials, their production, and processing for the implementation of a policy of long and healthy life and the care the level of health care in the world.

The paper is extensively illustrated with appropriate diagrams and figures drawn by the authors that complement the verbal content presented in the paper in a convincing and perceptive-friendly way. These figures are the quintessence of knowledge on specific issues, not an indirect transfer or quotation from any source. A detailed analysis of the content of these figures undoubtedly makes it easier to understand the complex content of the paper and is explaining and supplementing it. Carefully selected own photos illustrating, among others, materiallographic research results are presented, in the parts containing examples of practical and clinical activities of the authors.

\section{General Description of Health as a Universal Human Value and Assumptions of a Long and Healthy Life Policy}

The basic and currently common economic doctrine based on the Club of Rome's achievements in 1972 [1] and taking into account the theory of public good [2], assumes that sustainable development occurs. This concept's essence consists of meeting the current needs of the present generation to a degree that does not diminish future generations' chances to meet their needs appropriately [3]. Prosperity at the expected high level can be guaranteed if a balance is ensured between the sufficiently high economic status, ensuring the proper state of the environment, both natural and human-made, and properly shaped quality of life, health protection potential, the scope of education, the level of information 
flow and by implementing out of 17 Sustainable Development Goals designated by the United Nations UN (Figure 1) [4].

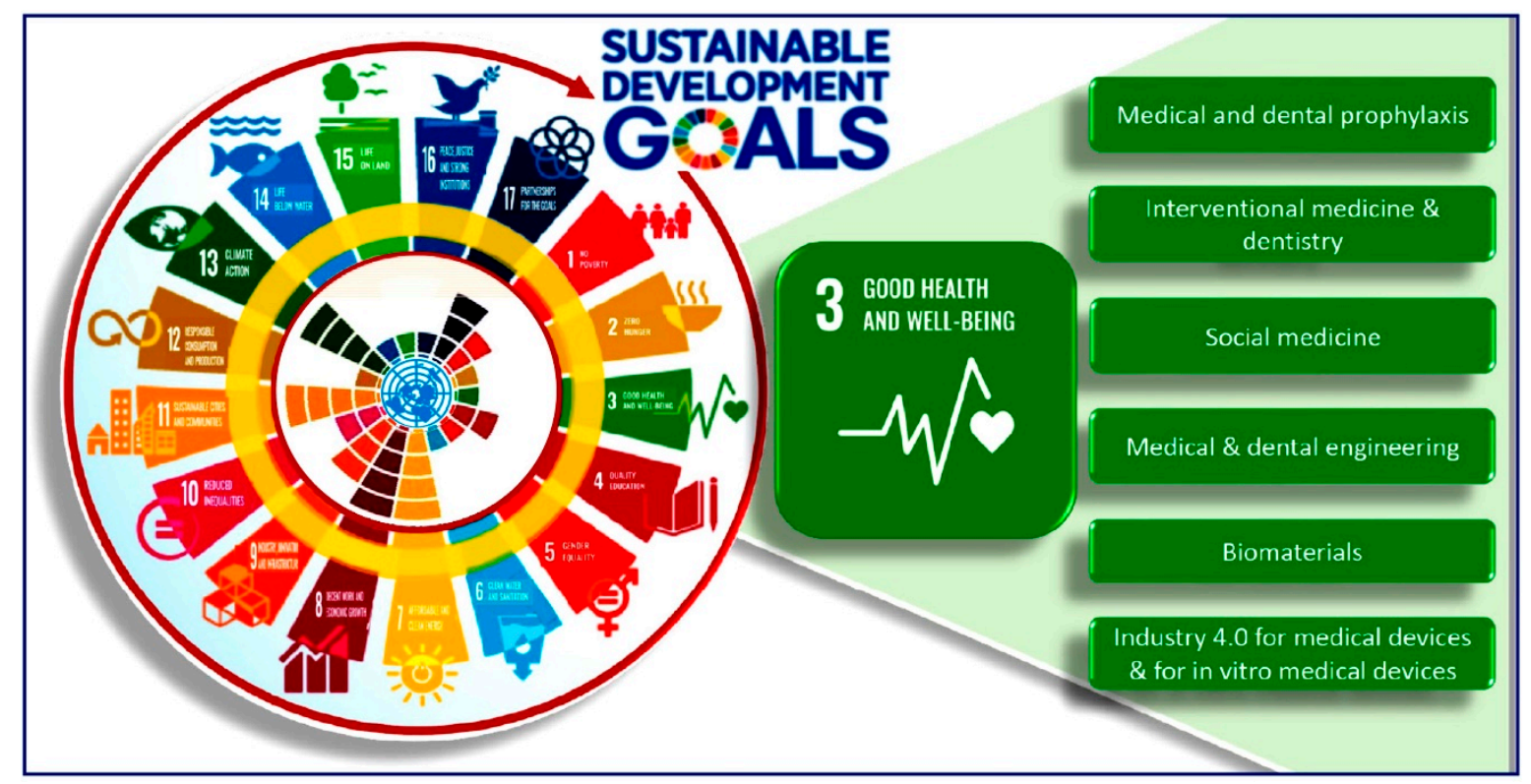

Figure 1. Diagram linking the UN Sustainable Development Goals with selected detailed aspects of good health and well-being of people, including the organization of medical care and the design and production of medical devices necessary in these activities.

The basis of this approach, which is of common interest to all societies, is the assumption that the standard and quality of life is provided to people through access to consumer goods and products. As any product requires the use of technical materials, most often engineering materials, although sometimes also natural ones, an important determinant of prosperity associated with high quality of life is development and research in materials engineering, including nanotechnology and surface engineering.

Among the UN's Sustainable Development Goals, good health and well-being occupy an important place, inextricably linked with the concern to extend human life and promote an aging society's health (Figure 1). It requires action in various medicine and dentistry areas and others that the general public is usually unaware of. The current crisis situation caused by the COVID-19 pandemic also requires an appropriate response in health security and the organization and modernization of health systems [5]. "The enjoyment of the highest attainable standard of health is one of the fundamental rights of every human being without distinction of race, religion, political belief, economic or social condition. The health of all peoples is fundamental to the attainment of peace and security and depends on the fullest cooperation of individuals and States" as established in the World Health Organization WHO Constitution of 1948 [6]. It is, therefore, obvious that access to healthcare should be universal. Taking responsibility for ensuring health and well-being requires the so-called, more and more often, the "whole of government", which boils down to working towards this goal by the general public [7]. Such actions are targeted at individual citizens by recognizing each of them's right to their own health and healthcare and protection against threats to their health and life. For example, these tasks are set out in detail in the European Health Strategy [8]. The EU4Health Program [5], to protect against serious health threats, especially such as diseases of affluence, pandemics, and bioterrorism by improving the health of society, medical care, and health safety, manifested in the prevention of health risks, early diagnosis of the disease, efficient and effective implementation of medical procedures, improvement of the effectiveness of health systems, modernization of health care infrastructure and comprehensive and developmental medical therapies [9]. 
Both good health and well-being and general social cohesion and equality are the determinants of economic development in individual countries and their regions. More equitable societies tend to be characterized by greater progress in various aspects of their development. The measure is the Human Development Index HDI [10,11], developed by Pakistani economist Mahbub ul Haq, calculated for each country and first time reported by the United Nations Development Program (UNDP)'s Human Development Report Office $[3,12,13]$ in 1990. In 2010 it was recognized that while HDI stands for an index of "potential" human development (corresponding to the maximum level of HDI), it could be achieved if there were no social inequalities between individual countries and people in these countries. Since such an assumption does not correspond to the truth, an Inequalityadjusted Human Development Index IHDI was introduced [14], which, taking into account inequality, gives the actual level of human development (Figure 2) [1].

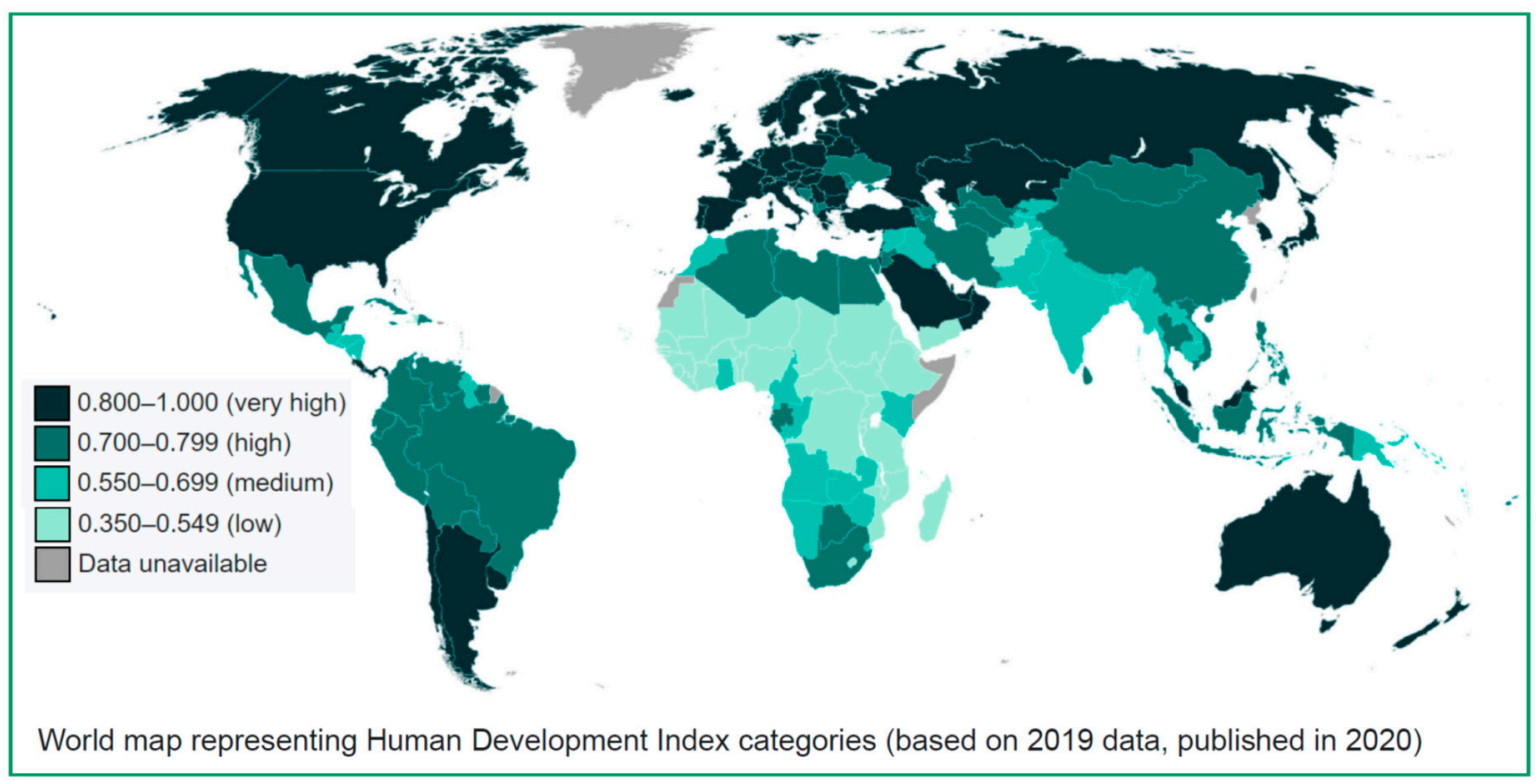

Figure 2. Geographical distribution of an Inequality-adjusted Human Development Index IHDI for individual countries.

These data were published firstly on 4 November 2010, but they were updated on 10 June 2011. Since then, the Human Development Report provides the calculated Inequalityadjusted Human Development Index IHDI values [15], taking into account three parameters to assess the quality of life which illustrate human development and well-being (Figure 3):

1. a long and healthy life index: life expectancy at birth,

2. an education index: expected years of schooling,

3. a decent standard of living index: gross national income (GNI) per capita at purchasing power parity (PP) (in international dollars).

Figures 2 and 4-6 show the indexes 'geographical distribution, as mentioned earlier', values according to the most available data. It is clear that there is an annual fluctuation in the details, but the overall view cannot be radically changed if the relevant data is from the past decade.

Thus, for many years, the health component has been included by the United Nations in assessing progress and the level of education and income assessment. There are many examples of it in many countries, including in the European Union, wherein the Treaty of Lisbon, Art. 3 states that "the Union's aim is to promote peace, its values and the well-being of its citizens". The Sustainable Development Strategy's goal is to "continuously improve the quality of life and prosperity on our planet for the present and future generations", while Art. 9 of the Treaty of Lisbon states that policies "should take into account the requirements of social protection, the fight against exclusion, the promotion of education and training and the 
protection of human health". Undoubtedly, health is both a measure and a goal of progress and development.

Inclusive development reduces inequalities through universal access to healthcare [16]. Improving health reduces development burdens and costs to society, health systems, and the economy in general. The proportion of the population experiencing adequate health care in low and middle-income countries (LMIC) is generally lower than in high-income countries (HIC). In each country, the poorest quintiles have the most inadequate coverage of medical services. Diseases typically reduce life chances, diminish dignity, and reduce individuals' productive contribution to society as a whole and their local communities.

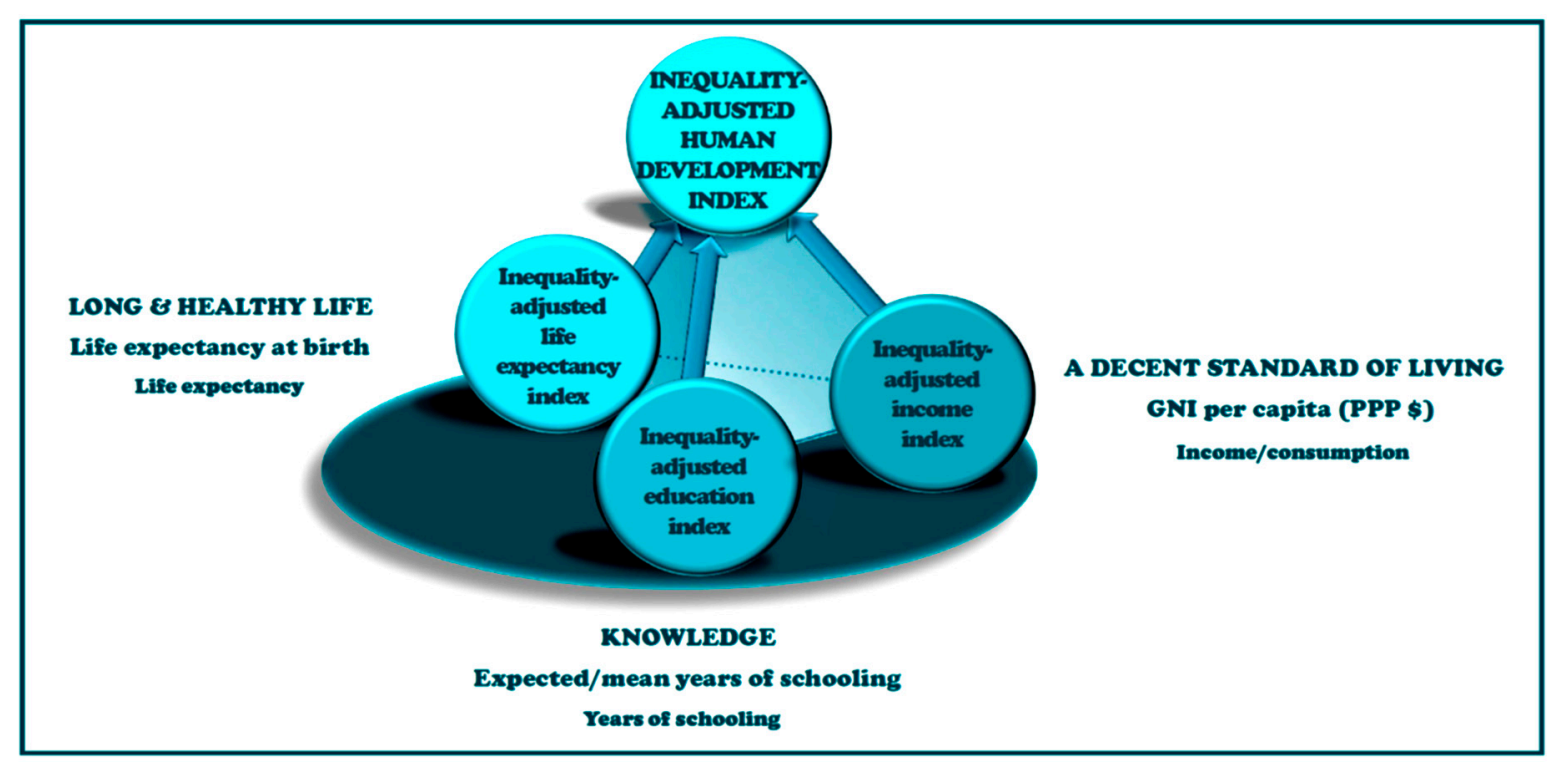

Figure 3. Diagram of the influence of various factors on Inequality-adjusted Human Development Index IHDI values.

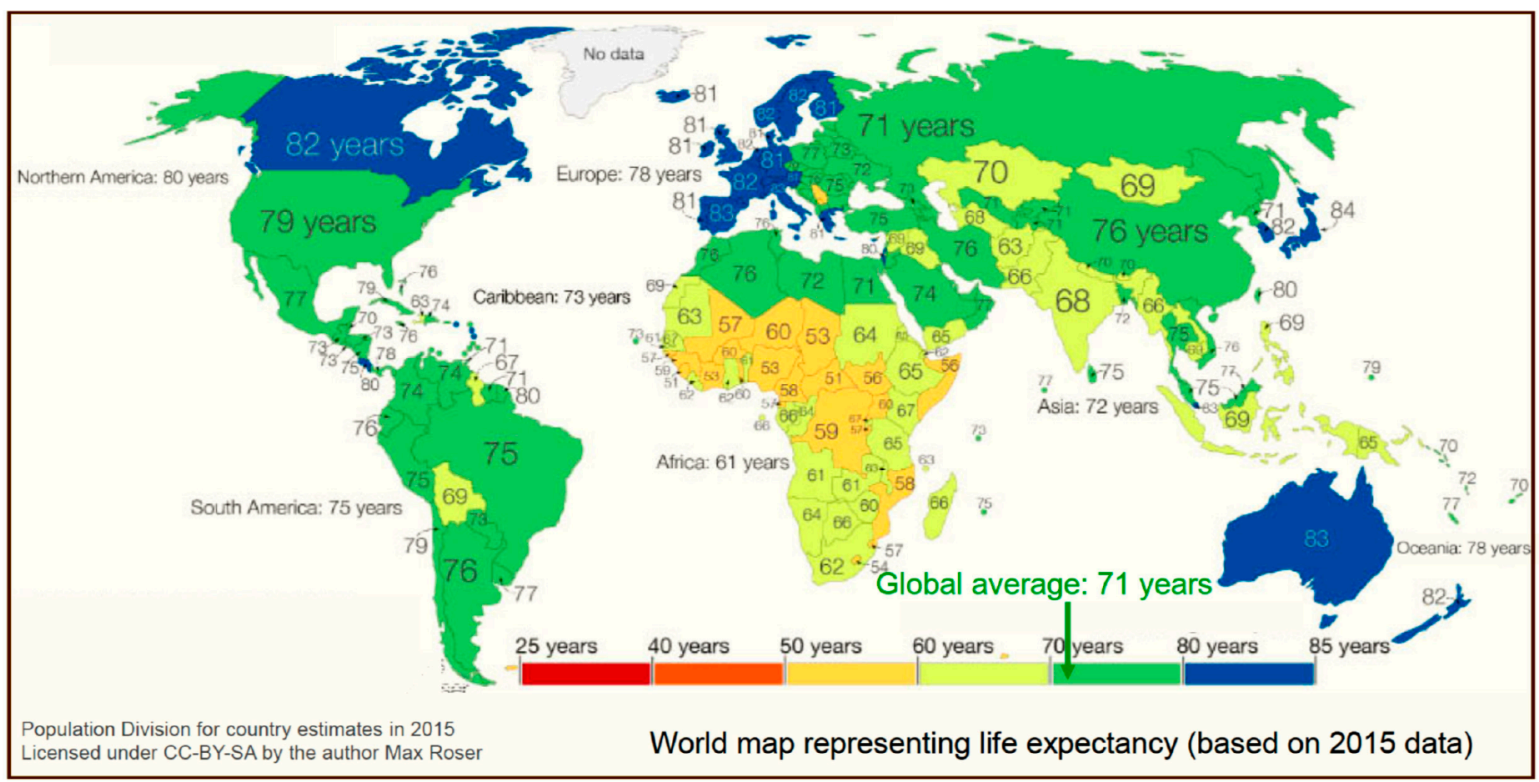

Figure 4. Geographical distribution of a long and healthy life index: life expectancy at birth. 


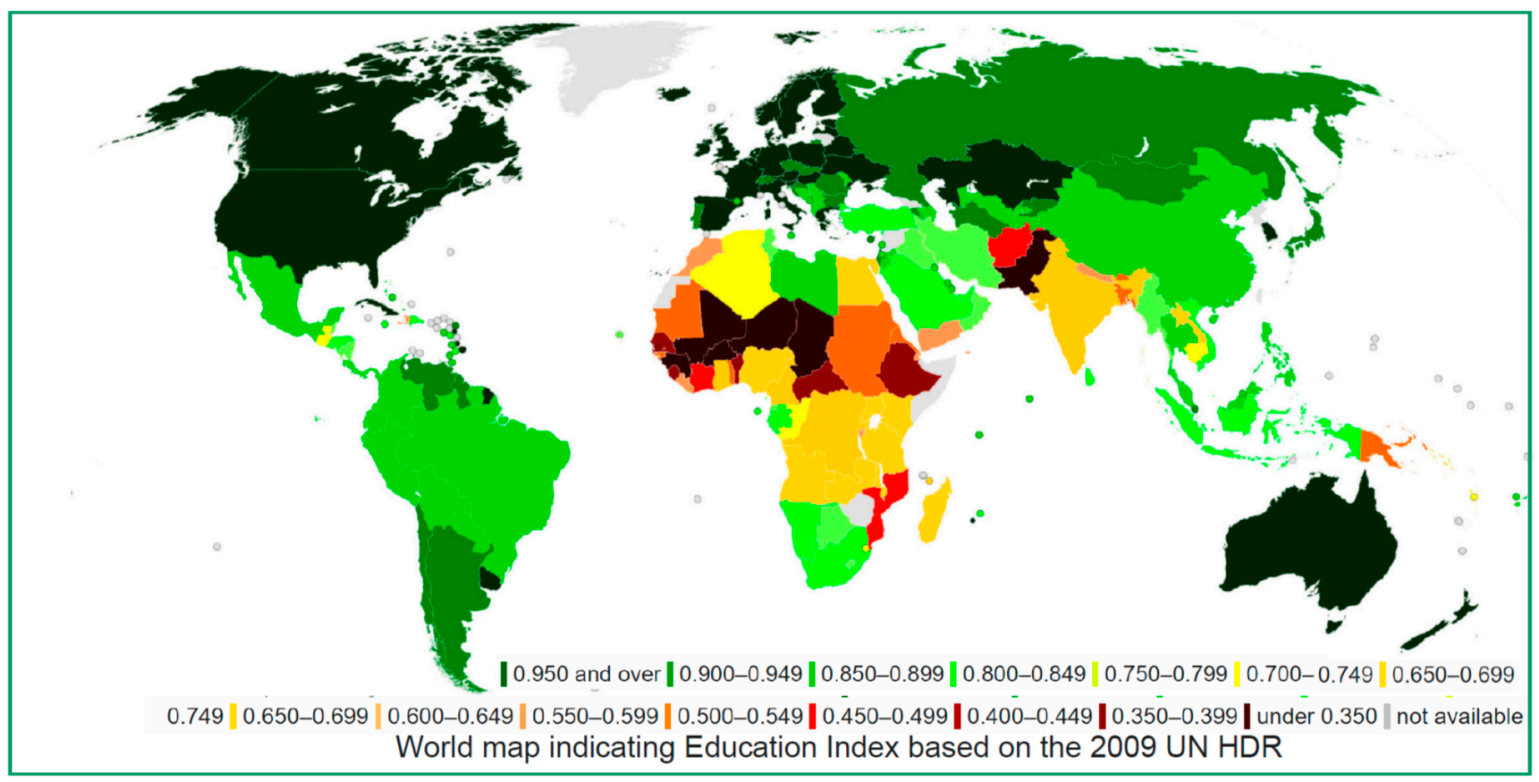

Figure 5. Geographical distribution of education index: mean years of schooling and expected years of schooling.

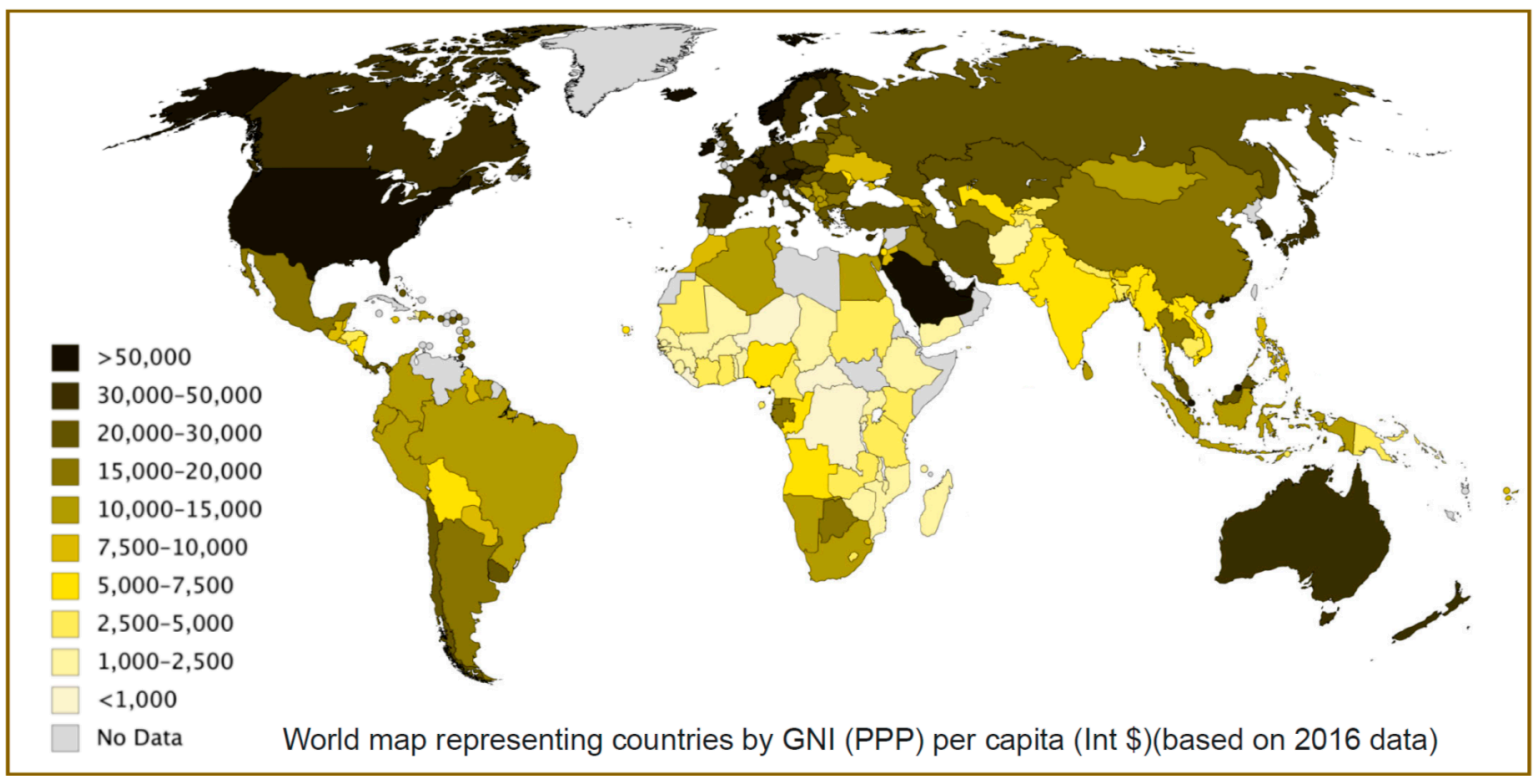

Figure 6. Geographical distribution of a decent standard of living index: gross national income (GNI) per capita at purchasing power parity (PPP) (in international dollars).

Figure 7 shows, for example, a comparison of mortality rates per 100,000 inhabitants by myocardial infarction and other ischemic heart diseases $[17,18]$ in the member countries of the Organization for Economic Co-operation and Development (OECD), which includes 36 highly developed and democratic countries [16,17]. Although all these countries are undoubtedly among the relatively best-off, the mortality difference between first, Japan, and last, Lithuania, is almost twelve times. Figure $7 \mathrm{~b}, \mathrm{c}$ compares these countries in terms of spending per person on health care [19-21]. Here the differences are even greater, as the difference exceeds 50 times between the USA and India. Figure $7 \mathrm{~d}$ compares the ranking of employment in health and social work as a share of total employment in these countries. There is an almost sevenfold difference between Norway and Mexico. It entails a variation in the number of doctors, which is already 20 times between Greece and Indonesia. One could conclude the creation of two-tier healthcare [17] was not because, apart from OECD countries, there are still many poorer countries. Therefore these differences are certainly 
much larger, although adequate statistical data for the whole world is not available. Undoubtedly, however, access to medical care varies greatly in different countries. Certainly, the situation is much worse in the LIC and LMIC countries. The lower and lower level of financing health care expenditure limits access to it and is the cause of deep social stratification in each country and differences between individual countries.

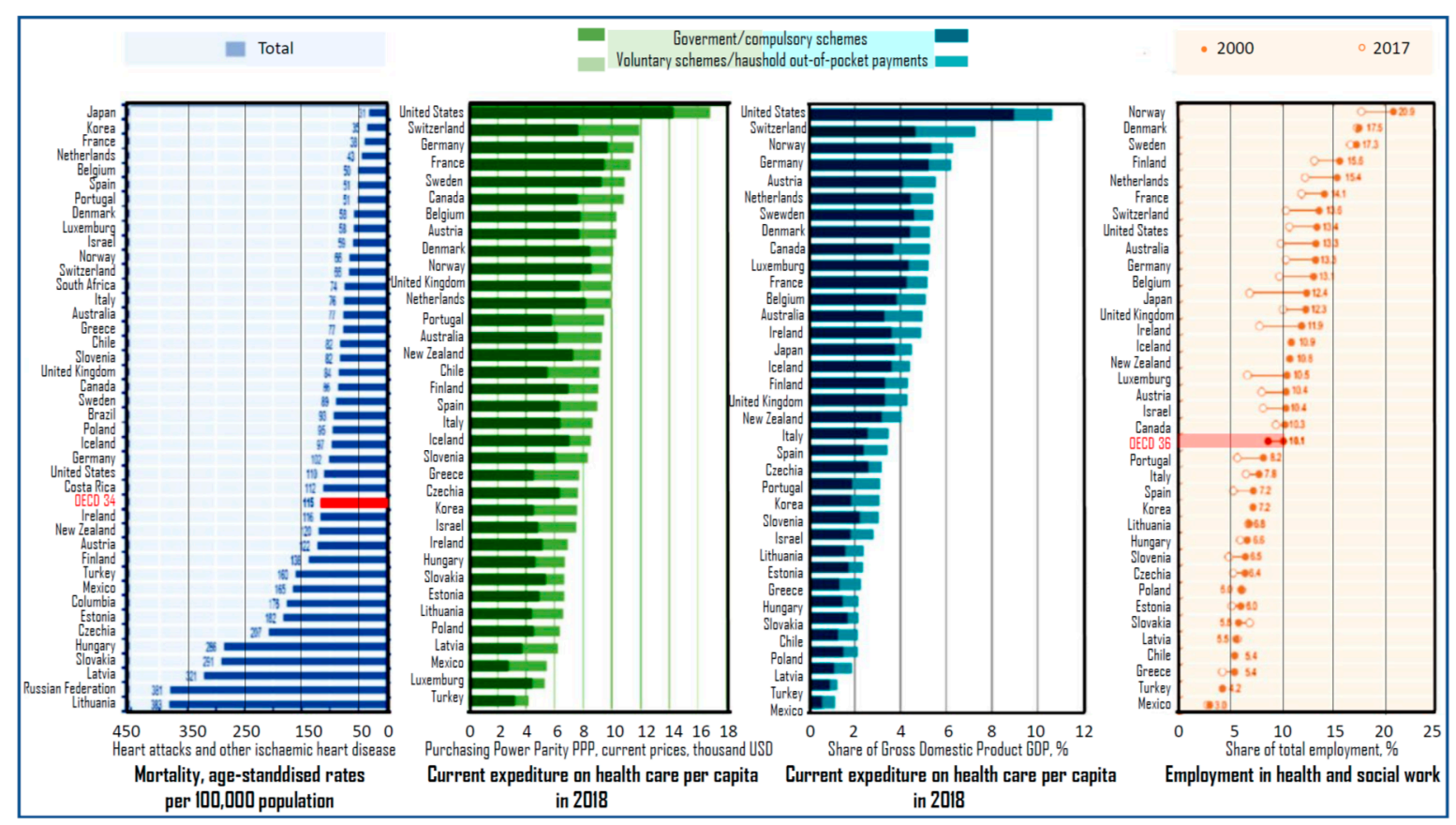

(a)

(b)

(c)

(d)

Figure 7. OECD countries compared in terms of (a) mortality rates per 100,000 inhabitants by a heart attack and other ischemic heart diseases in 2018; (b,c) health expenditure in 2018 per capita; (d) changes in employment in the health and social work as a share in total employment in 2000-2017.

However, when reaching the philosophical foundations of the concept of health, it should be noted that it is ambiguous and still raises numerous controversies. The ideas of health and disease are neither purely scientific nor solely part of common sense. They appear both in the conceptual apparatus of scientific theories and everyday thought. It cannot be concluded that the scientific and native application of the two concepts is completely independent.

The concept of disease evolves over time. It was believed that the disease was only an observable set of symptoms with a predictable course [22-24]. Its approach has become obsolete, and as medicine has developed, it has been established that disease occurs in the body as a set of destructive processes, "diverting part of the essence of an individual from actions that are natural to the species to another type of action" [25-28]. In the modernized, actuarial model [29], the disease is an increased risk, even without visible symptoms, in the event of a destructive pathological process, an example of which may be, for example, the hypertensive disease manifested by increased blood pressure [30]. The concept of disease in modern philosophy is more and more often seen as a set of empirical judgments on the one hand about human physiology and, on the other hand, normative judgments about human well-being or behavior [31-35]. The disease can be perceived as a process that repeats in different people in a slightly different form, so it is an abstract concept implemented in various ways [25,27]. In other fields of the humanities and social sciences, apart from philosophy, there is widespread support for the view that it is only normative judgments that determine the notions of health and disease [36,37]. Two basic ideas on the disease are emerged [38]. Objectivists, now more often referred to as naturalists [32,39-42], believe that the concept of disease is based on objective facts 
about the human body and that their correct interpretation and understanding in even the most difficult cases make it possible to define the boundary between health and disease. Assuming that the damage to health is a disease, an abnormality, or any biological defect, it can be concluded that health consists in the absence of any disease or such abnormality, and a healthy person is a person who has all biological systems fully functional. In the social consciousness functioning on an intercultural and over individual level, it is possible to mediate an individual's health objectively, e.g., with objective tests and research tools, as is usually the case in medicine. The beginning of medical objectivism was René Descartes's reflections on the mechanistic conception of the world and man [43]. The response to human diseases was reduced to repairing the damage to the biological machine man was considered to be, without considering it as a whole. In positivism, knowledge about man as a whole was considered the sum of knowledge about each of his components, which was separated for this purpose [44]. This approach's result was the perception of health as the absence of disease because the essence of health turned out to be too difficult to define. The same reasoning was adopted by WHO at its founding Assembly in 1948, accepting the International Lists of Diseases and Causes of Death [45]. Thus, health was defined as a condition in which none of the diseases thus defined occur. Quantitative indicators of disease occurrence or not, set by the physician, make it possible to judge the disease's state and by contrasting to determine the patient's health also, who is thus objectified. Therefore, one can adopt an external-conscious interpretation of both health and disease. Therefore, health objectivity, considering adopting various indicators or norms, enables the binary classification of a given person in one of the separate sets of healthy or sick people. Nevertheless, it is possible to formulate a broad spectrum of health for each person, from full health to terminal illness [46].

Constructivists take the opposite view, arguing that disease is an illusion and that disputed cases do not constitute ignorance of the facts but demonstrate a conflict of values between different social groups. Diseases damage them, for which a biological process is to blame, not their dysfunction [47]. Sometimes, however, there is a unification of views between these two views regarding the general acceptance of the system of values [38].

Philosophically or scientifically, it is very difficult to separate diseases and other ailments, including injury and/or disability [47]. Since the disease is a biological ailment, however, damages and/or disabilities can nevertheless be treated as events as they are not processes in essence. Similarly, it is impossible to separate disability from the issues of health and well-being. Usually, the problems of both disabilities, considered in the medical model as a product of physiological failure and/or human functional impairment, along with injuries and other diseases that do not require separation and the problem of diseases, are treated analogously. However, they are rarely analyzed jointly [48]. This approach to assessing organism disability is close to the naturalistic model of the disease. The condition of disabled people, similar to those affected by the disease, deteriorates due to functional impairments due to physiological or psychological inability to perform the organism's natural functions. In recent decades, a view has developed that disability cannot be treated as a dysfunction [11,22]. In the social model, disability is a simple difference between normal and healthy human functioning [49], and the diversity of these functions is a biological fact [50]. Therefore, the related differentiation does not result from physical disabilities but corresponds to social norms.

Consequently, it is necessary to analyze the health-disease-normality triad each time. According to [51], humans and their microbiomes are part of an ecosystem that can be assessed as healthy or not, so the analysis of health, disease, and normality should not be specific to individuals. Since it can be assumed that the human body belongs to the physical world, absolute health criteria can be determined by analogy to nature's laws due to the material from which it is made.

However, there is also a different approach to health, where it is determined not only by the absence of disease but also by its overall positive state. Therefore, total health can be understood as a multifaceted reflection of the synergistic impact of human psychology, 
physicality, and social relations that make up a specific person's well-being. In a relational approach, as stated in the first sentence of the WHO Constitution from 1948, "health is a state of complete physical, mental and social well-being and not merely the absence of disease or infirmity" [6]. Therefore, full health is guaranteed by the balance and integration of all these factors, complementary and autonomous at the same time. A person may feel sick, in the face of emotional problems or the case of social isolation, despite being fully physically fit. Conversely, he/she may consider himself healthy, despite his ailments or physical illness, in the event of inner mental strength and an atmosphere of social benevolence [52]. This ambiguity is the basis for criticizing the definition mentioned above formulated by WHO [53]. Based on the analyzes performed, three general categories of health can be formulated [54]:

- All healthy people must have the same health characteristics;

- Everyone is healthy in their own way;

- Health assessment criteria concern a set of universal and individual aspects.

"There is some intercultural agreement as to the basic characteristics of health, manifested primarily in the universal treatment of it as good, potency and activity" [55,56].

The unquestionable difficulty in establishing the essence of health is the dynamics of its changes over time. Moreover, it seems necessary to adopt the concept of health as a state of balance or a resultant balance between spiritual and bodily health [46]. There are doubts about whether the essence of health is related to man as such when it could only concern the civilization perspective. It is also worth noting that civilization's progress may introduce further changes and reevaluate the concept of health [46].

Regardless of the adopted philosophical view, the level of medicine, especially health care, significantly impacts a country's 'economic conditions and societies' health welfare. It raises certain serious professional and ethical obligations on the part of physicians and other healthcare professionals. Even in ancient times, the level of consciousness was so high that medics, and with time, doctors, were required to swear an oath regarding the morally appropriate level of performed tasks [57,58]. The Hippocratic Oath [59] has traditionally become a moral duty for all physicians to this day. Although its words changed, the meaning has remained the same for millennia. The doctor must help the sick, respecting the patient's autonomy [60,61], show charity [62], take actions that will not harm the patient under any circumstances [63], and be fair to the patient [64]. In this way, the generally recognized four basic ethical principles applicable to physicians were defined [65-68]. The doctor must also be truthful concerning the patient's health condition, the development and advancement of his disease, and the undertaken therapeutic activities. This principle has even been included as the fifth fundamental principle for dentists [69-72]. Doctors' ethical duties also include the systematic improvement of professional knowledge and the ongoing learning of scientific and clinical achievements, at least in their medical specialization. It is extended by the knowledge of appropriate technical solutions that can be used to improve the effectiveness of therapeutic activities undertaken by a physician. It applies in particular to modern diagnostic techniques, the possibility of using modern treatment techniques, especially surgical ones, the widespread use of the achievements of medical informatics and imaging methods, as well as modern surgical tools, as well as materials and technologies for the manufacturing of implants, but also, e.g., fillings used in dentistry and new materials and technologies for the production of prosthetic restorations.

Undoubtedly, the subject of this paper largely concerns the philosophical assessment of the current stage of development, goals, and threats of modern medicine. As mentioned earlier, the set as mentioned earlier of four basic ethical principles supplemented with the principle of truthfulness in relation to health and therapeutic activities constitutes the moral foundation of all medical activity undertaken over the millennia. Suppose you want to understand and at the same time explain any aspect of good health and well-being today. In that case, it is impossible not to refer to the moral imperative that every doctor and other person working in this important area of life must follow. It is obvious that every engineer who works with physicians to improve human health is also strongly morally bound to 
respect these principles. On the other hand, disregarding these issues would render such an analysis both incomplete and in many respects even non-purposeful.

It could also turn out that a medical device manufactured with or without the awareness of these aspects may lead to the fact that the undertaken therapy harms the patient directly in the short term, or systematically over many years, and in some extreme cases even lead to the death of the patient.

Therefore, these are only appearances that biomaterials are not related to ethics. Any biomaterial that in any aspect conflicts with any of the listed basic ethical principles can never be applied by a doctor, e.g., as an implant or other medical device, making engineering activities in this area completely pointless. Therefore, engineers working in this area are strictly subject to the moral imperatives in force and expected in this regard. One of the goals of this paper is to clearly emphasize the importance of these aspects in the context of the design, manufacturing, and application of biomaterials.

\section{The Impact of the COVID-19 Coronavirus Pandemic on the Health Situation in the World}

When analyzing the global health level in the second year of the severe acute respiratory syndrome pandemic caused by the SARS-CoV-2 COVID-19 coronavirus, this aspect's importance should be considered. The appearance of this creation of nature with a size of 100 trillion times shorter than the globe's size caused unimaginable changes in the world and resulted in virtually nothing returning to its original state from before the pandemic. As of the first identified cases in Wuhan, China, in December 2019, the disease has spread worldwide (Figure 8) [73-88], and lives have lost more than 2.5 million people (Figure 8).

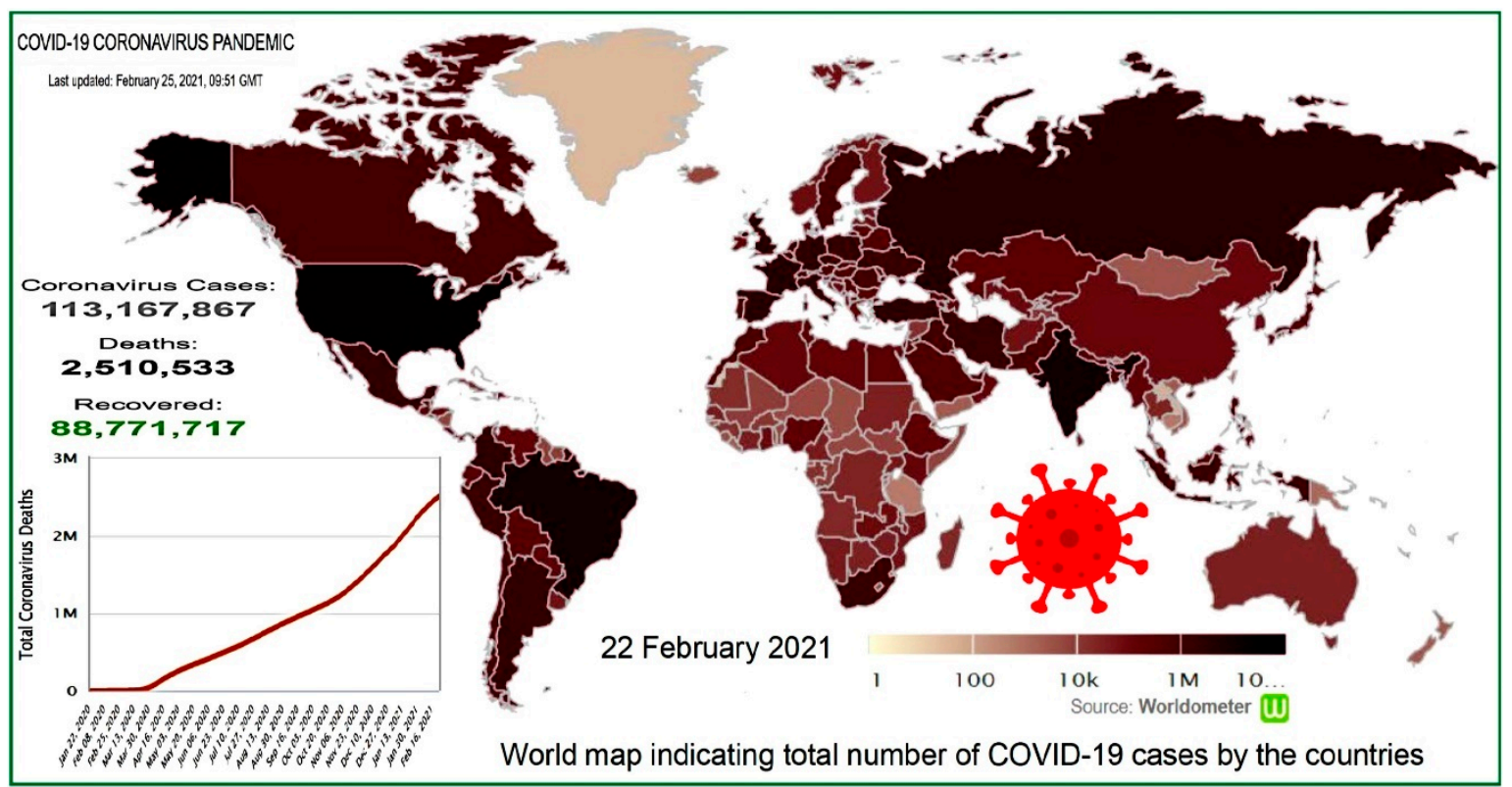

Figure 8. Spread of the COVID-19 disease in various countries of the world as of 22 February 2021.

For example, during a ceremony at the White House on 23 February 2021, US President, Joe Biden, in commemorating 500,000 people who died after being infected with COVID-19 in the US, stated that the disease in the US has so far claimed more lives than in World War I and II combined with Vietnam War. It illustrates the scale of this destruction.

Doctors, paramedics, nurses, and other health professionals, including dentists working in the respiratory tract of patients and ENT specialists, have become numerous victims of the SARS-CoV-2 coronavirus pandemic, many of whom, unfortunately, died in various countries. Figure 9 shows an example [89] of the spread of the coronavirus in a dental clinic. 


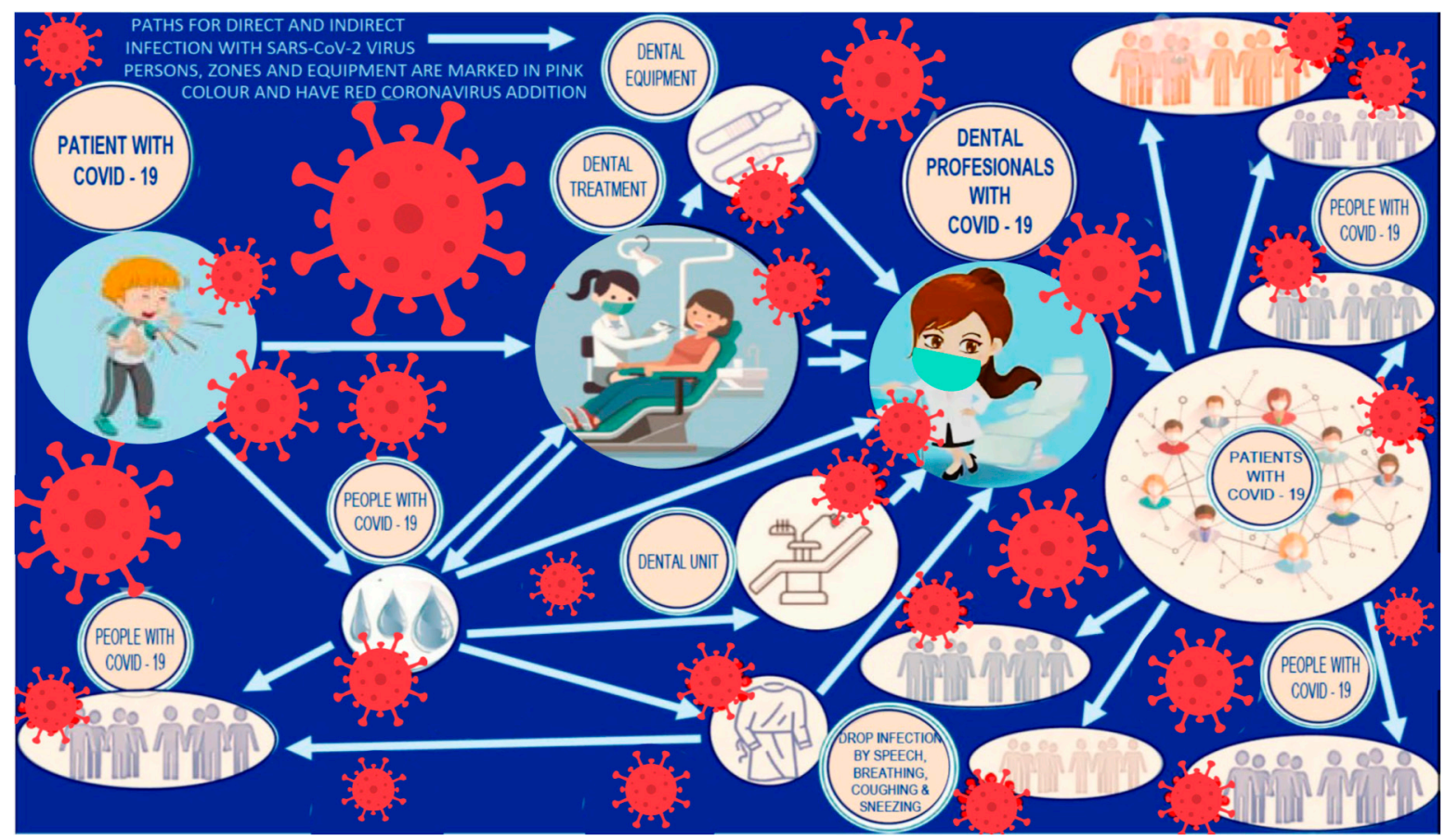

Figure 9. Scheme of SARS-CoV-2 coronavirus transmission as a result of primary infection of the dentist by one sick patient.

Figure 10 shows the life cycle of the SARS-CoV-2 coronavirus along with the potential induced immune responses [90]. Airborne droplets carry out the transmission of the SARS-CoV-2 coronavirus to infect the mucosa cells after reaching the oral cavity and respiratory tract. The angiotensin-converting-enzyme ACE-2, which is identified as a receptor by the coronavirus spike receptor protein, exists in the human lower respiratory tract. The interaction of the spike coronavirus receptor protein with human cells is the initial stage of infection. Then the ribonucleic acid RNA of the viral genome is released into the cytoplasm [91]. RNA occurs in the cell nucleus and the cytoplasm and is the carrier of information between deoxyribonucleic acid DNA and proteins. RNA components are nucleotides whose sequence depends on the order of these particles in DNA. RNA carries the genes of many viruses. RNA is typically single-stranded. In the case of single-stranded molecules, especially those having enzymatic functions or cooperating in these functions, the formation of double-stranded fragments by pairing different sections of the same strand determines the structure of the entire molecule. Their polarity characterizes RNA viruses containing a single strand of nucleic acid. The SARS-CoV-2 virus has a single-stranded RNA genome wrapped in a nucleocapsid $(\mathrm{N})$ protein and three major surface proteins: the membrane (M), the envelope (E), and the spike (S), replicated to pass into the lower respiratory tract. It can result in severe pneumonia. The spike fusion protein of the virus plays an important role in penetrating the SARS-CoV-2 coronavirus into human cells [92]. In the first stage, the $\mathrm{S} 1$ glycoprotein determines the viral entry into the cell. In contrast, in the next stage, the human cell fuses with the viral envelope with the participation of S2 glycoprotein [93]. The human angiotensin-converting enzyme 2 hACE2 receptor protein acts as a receptor for this coronavirus, thanks to the SARS-CoV-2 Receptor-Binding Domain RBD [94-101]. It is the cause of the multiplication of the SARS-CoV-2 coronavirus, including in lung tissues, intestinal epithelial cells (enterocytes), kidneys, and blood vessels where hACE2 is present [102,103]. However, not only the hACE2 protein is a receptor in cell fusion because the SARS-CoV-2 coronavirus, to bind to the receptor of human cells, also activates them through their proteases [104]. Unlike the active standing position of the dynamic property of the RBD domain of other viruses, in the case of SARS-CoV-2, the RBD is usually in a prone position, which makes binding to a human cell receptor through it impossible. Endocytosis is the main way this coronavirus enters human cells. Endocytosis refers to the penetration of larger molecules inside the cell that are too large to be transported by protein 
transporters. Therefore, vacuoles are formed, and coronaviruses enter the cell along with fragments of the cell membrane. In addition to the hACE2 receptor, cell fusion activation can also be caused by the body's furin enzyme [100,105-109]. Inhibition of this enzyme may imply a potential antiviral strategy [105-108,110]. Necessary in this process is the phosphoinositide kinase enzyme PIKfyve containing five fingers, the TPCN2 dual-pore calcium channel protein, and the cathepsin CTS toll-like receptor 7 TLR7. TLR7 is one of the endolysosomal proteases whose role is to regulate innate and acquired immunity, including cell adhesion and migration, processing, antigen presentation, and resistance to various viral infections. It is necessary for the cleavage of TLRs and the formation of functional receptors that enable the detection of viral nucleic acids such as RNA or DNA [109]. The transmembrane protease enzyme serine 2 TMPRSS2 is also important in the pathogenesis of SARS-CoV-2, the protease responsible for cell fusion with the S protein of this coronavirus and induces the formation of syncytium [111,112]. The syncytium is a multinuclear cell (multinuclear mass of protoplasm) formed by the fusion of loose single mononuclear cells, with the simultaneous disappearance of the surrounding cell membranes. The SARS-CoV-2 coronavirus may most likely form a syncytium depending on the activity of the receptor but independently of the protease and also without the participation of trypsin [109]. Trypsin belongs to endopeptidases and is a digestive enzyme produced by the exocrine part of the pancreas in the form of a proenzyme-trypsinogen, an amount of pancreatic juice. Trypsin is also able to generate syncytium through activation of S-glycoprotein. The cumulative effect of TMPRSS2, lysosomal cathepsins, and furin on the cellular penetration of SARS-CoV-2 has again been proven. Thus, blocking TMPRSS2 may be one of the treatments for COVID-19 [112-114]. Blocking the cell surface receptors helps the virus replicate. The use of an angiotensin-converting enzyme may be one way of preventing viral infection $[115,116]$.

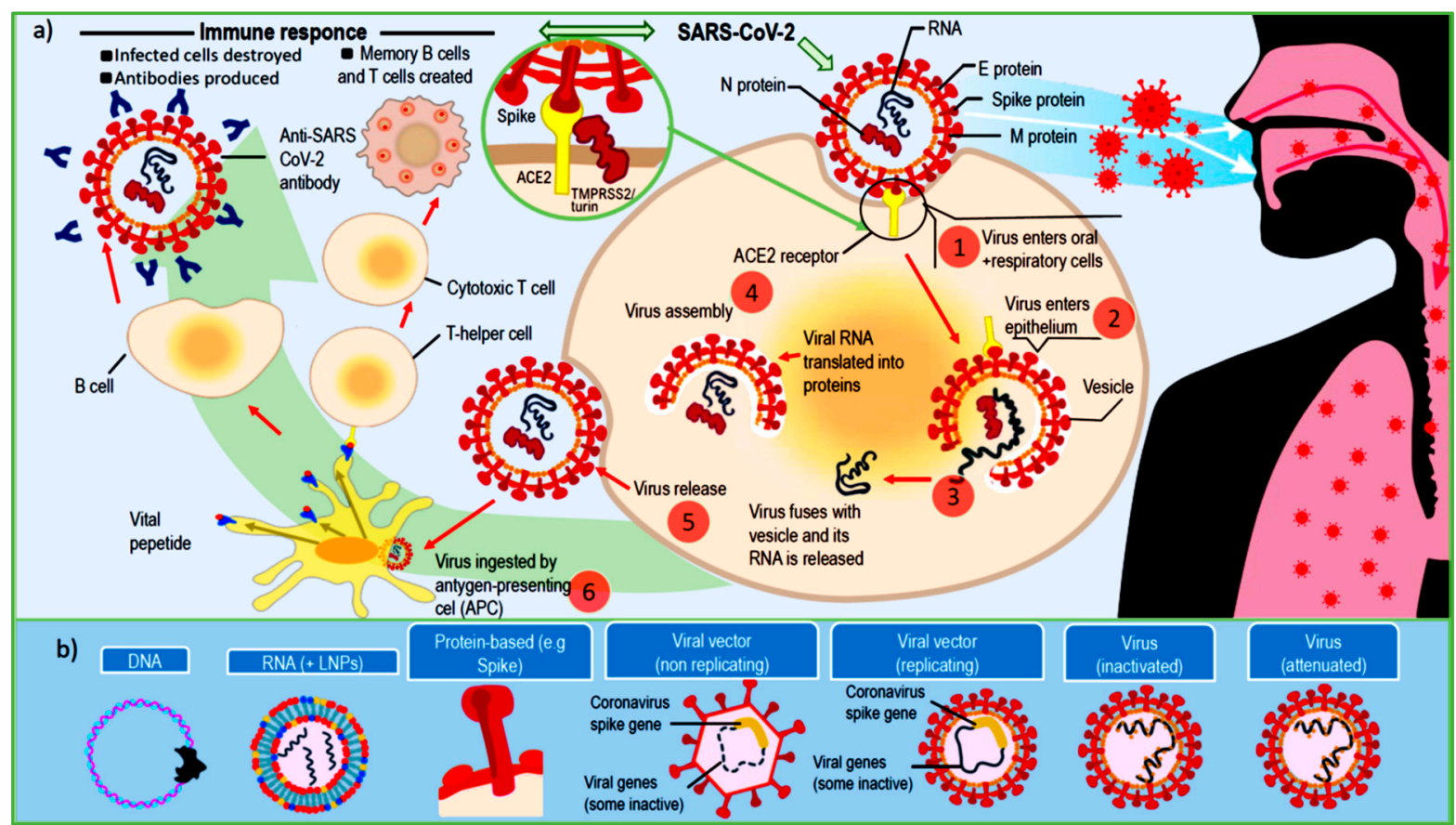

Figure 10. Diagram of (a) transmission and life cycle of the SARS-CoV-2 coronavirus; (b) preventing modes of SARS-CoV-2 coronavirus infection.

From the epidemiological point of view, patients who do not show clear or no disease symptoms are dangerous, especially as they constitute over $30 \%$ of the population, while effectively transmitting the disease $[78,79]$. Severe symptoms of the disease, manifested by dyspnea, hypoxia and resulting from the involvement of more than $50 \%$ of the lungs, occur statistically in about $14 \%$ of cases, and in another $5 \%$ even acute symptoms of the disease, 
apart from respiratory failure, manifested by shock or multi-organ dysfunction [78], which often leads to the death of the patient due to irreversible lung damage due to fibrotic pathology and the inability to withdraw from mechanical ventilation or extracorporeal life support. In some cases, it can be counteracted by lung transplantation [117]. Statistics show a very high recovery rate, although some convalescents experience so-called long COVID, causing damage to various organs over time [81], which is still under constant investigation.

Research activities have been undertaken to develop anti-virus drugs, and work is still ongoing, although there are no measurable effects to date. Therefore, almost exclusively symptomatic treatment, supportive care, isolation, and severe cases, oxygen therapy, special treatment methods, and even experimental methods are used [118].

In many countries, numerous preventive measures are taken to minimize virus transmission risk, especially in public places. These activities mainly include social distancing, disinfecting, washing hands, keeping unwashed hands away from the face, covering up coughing and sneezing, using masks or face shields, ventilating rooms, physical or social isolation, quarantine, shutting down various sectors of the economy, shutting down schools and universities and a total social and economic lockdown.

As the number of COVID-19 cases continues to increase, the professional healthcare system is facing growing challenges. One of the important elements of this approach is the protection of doctors and other medical staff because only their efficiency gives any chance of survival to millions of people in the world in the face of the threat of a fatal disease. Various practically used methods were compared by performing a benchmarking analysis and using the dendrological contextual matrix (Figure 11) [89,119-121], analogous to the matrices of Boston Consulting Group introduced in the 1960s [122]. Figure 11 also shows all types of applied solutions and their total assessment made based on the criteria of potential and attractiveness given in this figure.

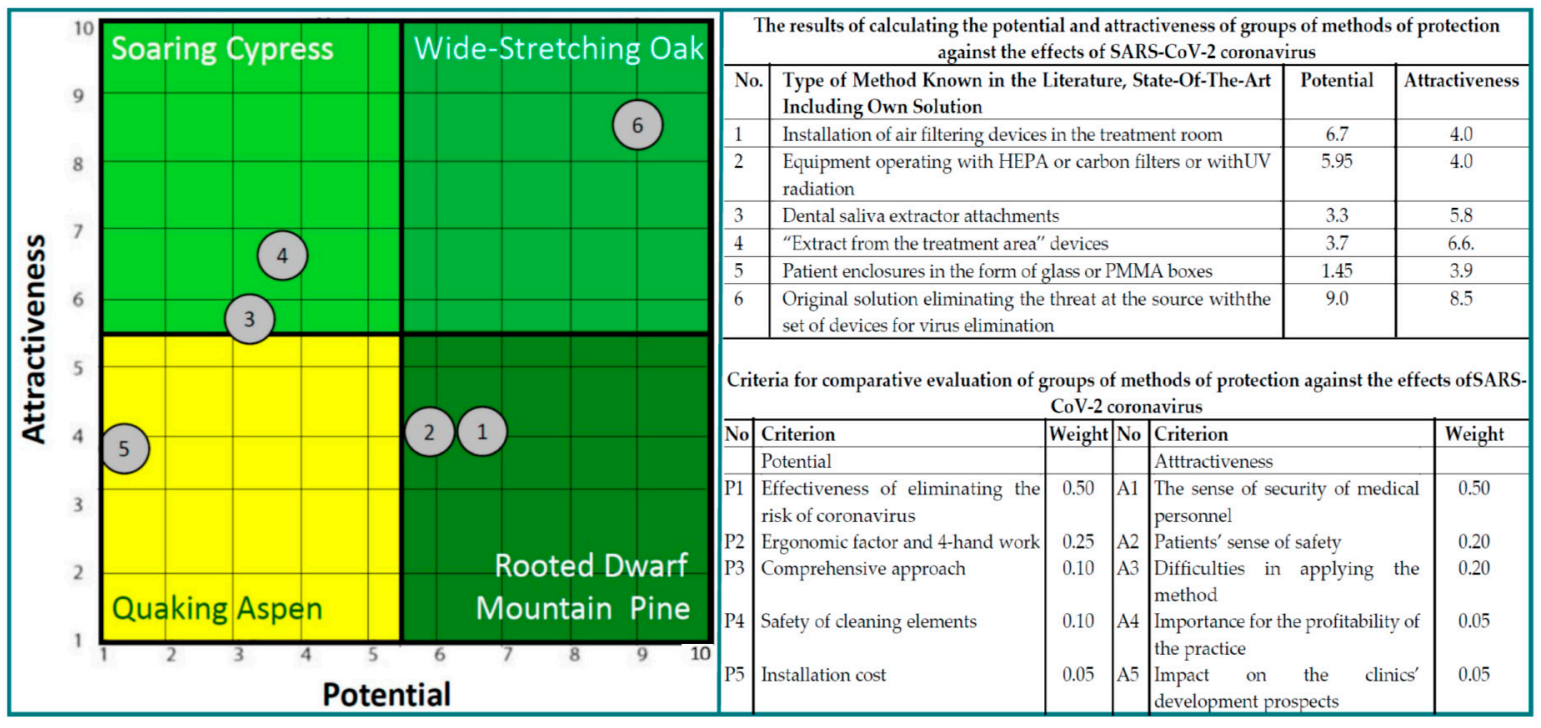

Figure 11. Results of a comparative analysis of various methods of protecting medical staff against the harmful effects of the SARS-CoV-2 coronavirus.

Assessment results are plotted on a dendrological matrix. The quarter "Rooted dwarf mountain pine" includes proven, mature methods $(1,2)$, which have great potential but may currently have complementary importance. "Soaring Cypress" is a quarter containing very attractive methods $(3,4)$, with possibilities for the future but requiring consolidation to be able to apply them more widely. Weak in the "Quaking Aspen" quarter, there are low potential and attractive methods (5), replaced with better solutions. The authors' solution (6), which eliminates the threat at the source with a set of virus elimination devices, is located in the "Wide-stretching oak" quarter and is characterized by the greatest number 
of new products, objectively presented and groundbreaking meaning. However, the other methods are relatively but only seemingly much more attractive (subjective impression of the recipient) than their real potential (objective technical analysis). Therefore, their importance is overestimated, despite their objectively weak usefulness.

A common approach to solving the problem is the STOP strategy. With this approach, the protection of medical personnel against epidemiological threats consists in the successive implementation of more and more radical measures, from systemic solutions to technical and organizational solutions in the use of personal protective equipment. In the most radical approach, doctors and nurses equipped with appropriate hermetic coveralls, gloves, and helmets are completely isolated from the contaminated environment with infected patients. This method almost completely limits the freedom of movement, exposes to sweating and extreme thermal discomfort, shortens the effective working time, and greatly complicates the liberty to perform precise medical procedures, such as surgery or dentistry [89]. An almost opposite approach is represented by the proprietary SPEC strategy, which can be used in dentistry, ENT, and anesthesiology. This breakthrough strategy isolates the patient and the bioaerosol he exhales, as well as the clinical aerosol associated with dental procedures, from the physician and the medical treatment room (Figure 12). Bioaerosol and clinical aerosol are eliminated at the source. The solution hits the cause to eliminate the causative factor. A comprehensive set of devices for collecting the aerosol is right next to the patient's mouth, and complete deactivation of this aerosol after collecting in appropriate containers. The modular structure of the system protects medical staff against coronavirus and other pathogens. The face shield is an important element of this solution, and therefore one variant is shown in Figure 12. The study [89] also compared this solution with the concepts of all other available personal protective equipment for medical personnel against pathogens.

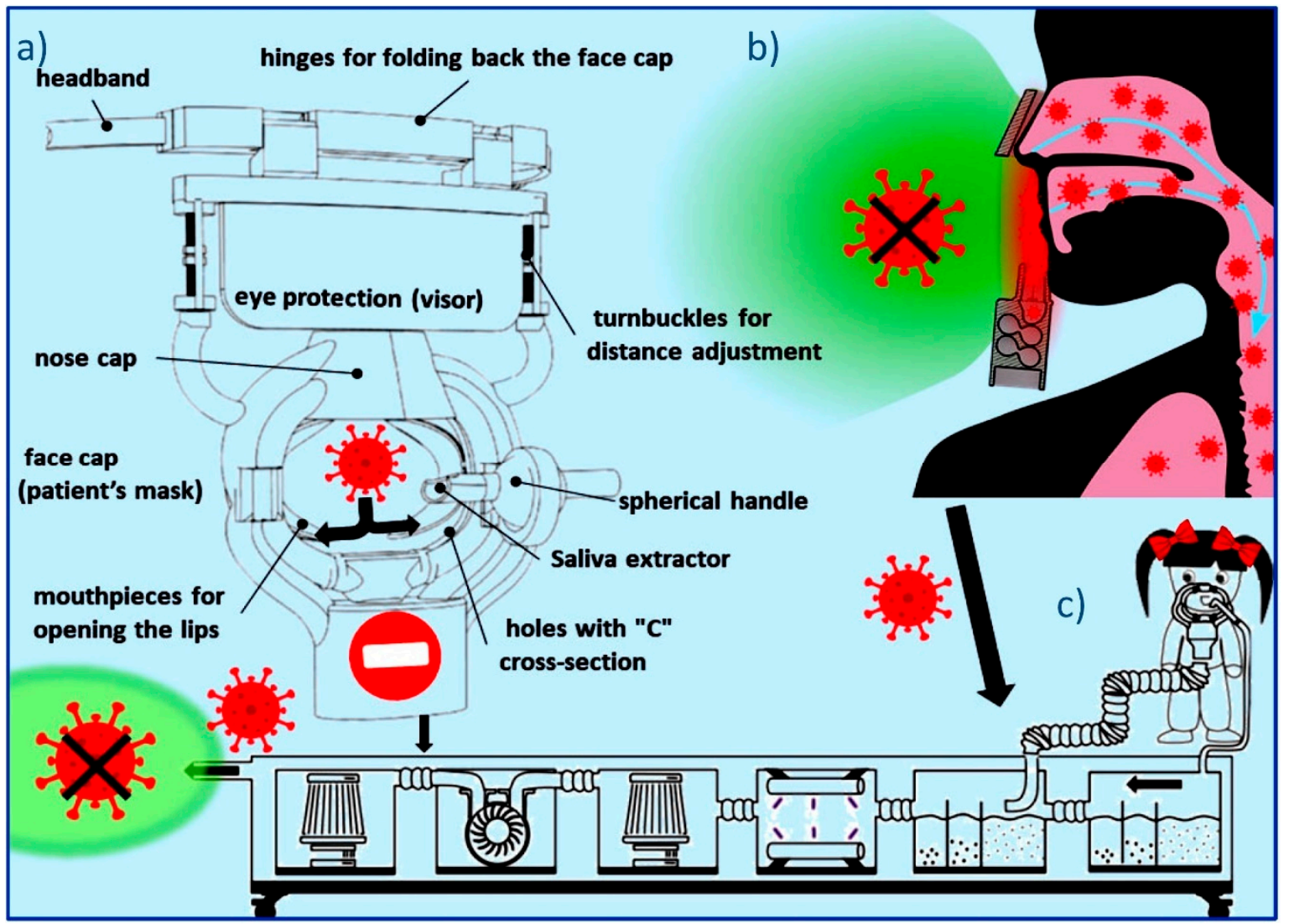

Figure 12. Diagram of the medical staff protection system against the transmission of the SARS-CoV-2 coronavirus: (a) diagram of the face shield with a full set of utility functions; (b) a source risk elimination scheme; (c) a set of devices for inactivation and decontamination of the coronavirus. 
The importance of preventive vaccinations against the SARS-CoV-2 coronavirus cannot be overestimated. The different ways to prevent viral infection are given in Figure 10b, which breaks down all SARS-CoV-2 vaccine candidates into seven major platforms (DNA, RNA, protein-based, viral vector (non-replication), viral vector (with replication), virus (inactivated), and virus (activated)), represented by different regimens. As of February 2021, 66 vaccine candidates are undergoing clinical trials in various stages. As of February 2021, 11 vaccines have been approved for public use against COVID-19, which have gained acceptance in at least one country, and fall into four groups of vaccines:

- Two RNA vaccines (Pfizer-BioNTech and Moderna),

- Four conventional inactivated vaccines (BBIBP-CorV, Covaxin, CoronaVac, and CoviVac),

- Four vaccines with viral vectors (Oxford-AstraZeneca, Convidicea, Johnson \& Johnson, and Sputnik V),

- $\quad$ One peptide vaccine (EpiVacCorona).

Many countries have implemented distribution plans that prioritize those at the highest risk of complications, including healthcare system staff due to the high probability of infection and transmission of the coronavirus and the elderly with the lowest individual immunity [123]. According to official data from national health agency reports, 216.17 million doses of the COVID-19 vaccine have been administered worldwide so far until 23 February 2021 [124]. The vaccination campaign is intense all over the world. However, it is worth noting that it is unfortunately impossible to guarantee full immunity to the COVID-19 disease. Simultaneously, the vaccination of about $60-70 \%$ of the world's population and the population of all countries in the world gives a great chance to weaken both the virus's aggressiveness and mortality. Unfortunately, the virus mutates, and it is not certain that any of the vaccines invented and implemented so far gives resistance to mutating variants of the virus.

It should be expected that a similar situation may occur as in the case of acquired immune deficiency syndrome AIDS, i.e., a disease caused by human immunodeficiency virus HIV, which is transmitted not only through sexual contact and perinatal, but also through exposure to secretions or tissues containing the virus, including, e.g., through the blood. Despite the fact that the epidemic conditions have subsided, all health care staff to this day use restrictive procedures to prevent accidental contact with blood, saliva, and other secretions or tissues of potentially infected patients with this virus, that is in practice against all patients for prevention [125-129].

It should be anticipated that, analogically, even in the event of an end to the COVID-19 pandemic and in the event of high effectiveness of vaccines, in the absence of certainty that the protection in this respect is fully effective, it will be necessary for doctors and other medical staff to apply preventive measures, according to appropriately adapted strategies STOP and SPEC, protecting against the transmission of SARS-CoV-2 coronavirus and its subsequent variants, including British, South African, Indian and Brazilian ones [130] and all others that may emerge in the future.

In the book "Science of Logic" from 1812, the German philosopher Georg Wilhelm Friedrich Hegel (1770-1831) formulated the thought that "Purely quantitative changes at some point turn into qualitative changes." The scale of the SARS-CoV-2 pandemic in a little more than a year around the world makes it a serious qualitative change. Millions of people worldwide get sick, millions of people have lost their lives because of it. Among them were numerous doctors, nurses, paramedics, therapists, and diagnosticians. They died because they saved the lives of others, their patients.

Since the first five cases of human immunodeficiency virus, HIV, infection causing acquired immune deficiency syndrome, AIDS, were recorded in 1981, according to estimates by the World Health Organization (WHO), the disease has affected approximately 80 million people since the beginning of the epidemic, of which over 35 million people died. Since then, the approach of all physicians to protect themselves from infection has changed. Infection with the hepatitis $\mathrm{C}$ virus HCV is similarly dangerous, for the discovery of which Harvey Alter, Michael Houghton, and Charles Rice received the Nobel Prize in medicine in 2020. It is estimated that about 170 million people are infected with HCV in 
the world. Blood may also be among the epidemiological routes of infection. Today, no one doctor or dentist will start the medical procedure unless they put on gloves, although not each patient can infect them through the blood. However, it will be enough if it is one in a thousand or even in several thousand. The infection will be fact and death could happen.

Routine safety and precautionary measures should be taken as each physician knows and follows them.

In essence, completely different measures must be taken than in HIV or HCV due to the other way of transmitting the SARS-CoV-2 coronavirus. The approach to continuous and systemic protection against this pathogenic and dangerous virus will remain unchanged, but the mode should be absolutely unique and different.

Airborne droplets spread the SARS-CoV-2 virus. It is virulent, lethal, and is very difficult to protect against. Doctors cannot risk their lives saving someone else's life and losing their own life. This fact completely changes the approach to medicine. As authors, we realized that ensuring the safety of doctors and other members of the medical staff is an important part of modern medicine and even becomes hierarchically superior to the normal routine preventive, diagnostic, therapeutic, and interventional activities, including implantology, and organ transplantation. The people should know it because everyone will one day be a patient. That is why the safety aspects of medicine need to be addressed in the paper on biomaterials. There is a need to change the approach. Appropriate protective equipment against SARS-CoV-2 according to authors' SPEC strategy should be produced, which will allow doctors to work normally, without having to wear personal protection equipment resembling a spaceman's outfit, and at the same time so restraining to movements and not providing any thermal comfort, and to perform many precise medical procedures. A new generation of preventive measures requires the use, and perhaps even the development and manufacturing, of a new generation of biomaterials for this type of medical device. Looking at the problem of biomaterials holistically, it is impossible to ignore this problem. It is the justification that one part of this paper is dedicated to this issue.

\section{The Necessity for Physicians to Use Technical Solutions Supporting Medicine and Dentistry}

The basic philosophical approach of medicine is disease prevention. Considering the relationship between health and economic well-being requires the support of scientific research and the development and application of advanced technologies related to medicine's technical support to ensure the fullest possible prevention of diseases. It requires a very wide-ranging and planned action by entire national health systems. However, practice shows that despite the great efforts, activities of many people, and huge financial outlays, such activities cannot protect all patients from the disease. An example is dentistry. It is estimated that 3.5-5 billion people worldwide, i.e., up to $60 \%$ of the population, suffer from caries, leading to toothlessness and many systemic complications. Many people also suffer from periodontal diseases, which leads to similar complications [16]. In such cases and many other cases, e.g., in orthopedics, heart diseases, and cancer, it is necessary to treat patients using interventional medicine methods safely. In traumatology, orthopedics, maxillofacial surgery, and dentistry, it is often required to replace or supplement organs or tissues to restore patients' vital functions and prevent their biological and social degradation today is both an avant-garde and an expensive branch of modern medicine [5]. The number of cases requiring this type of intervention is systematically increasing. The dynamics of this growth is closely related, inter alia, with surgical treatment of neoplastic tumors, often saving human life and removing inflammation, numerous road accidents and the resulting serious injuries, sports accidents related to, among others, with extending human life and practicing various sports by elderly people, as well as with the spread of caries, periodontal diseases and increasing the scale of edentulousness [16]. For example, in the European Union, around 1.7 million people are injured in road accidents each year, according to the Association for the Improvement of Road Safety. In comparison, an average of about 6.1 million people is hospitalized in hospitals each year. It is predicted that the 
number of patients requiring replacement or replacement of organs or tissues, including dental implantology, will systematically increase along with the extension of human life and increase people's participation over 65 in the total population, which will increase by approximately $70 \%$ by 2050 [9].

Achievements in the field of implantology, prosthetics, tissue engineering, and natural organ transplants, serving specific patients directly, setting the latest trends in medicine and interventional and regenerative dentistry, have their sources in the deep knowledge and experience of doctors and biologists, what is obvious. However, the enormous achievements in the field of engineering, generally referred to as bioengineering, with the participation of medical and dental engineering, including, among others, advanced modeling, computational science, and computer-aided engineering design, materials engineering, materials process technologies, and manufacturing engineering together with additive technologies, nanotechnology, and surface engineering (Figure 13). Bioengineering is richly collaborative and interdisciplinary and focuses on integrative applications and solves problems left unanswered by engineering and physical/life science disciplines [131,132]. The diagram shows the multidisciplinary nature of this engineering discipline in the form of a multicoloured flower. Each of the petals corresponds to a different area of knowledge contributing to it. In the central part, various areas of interest in science and engineering are specified as examples.

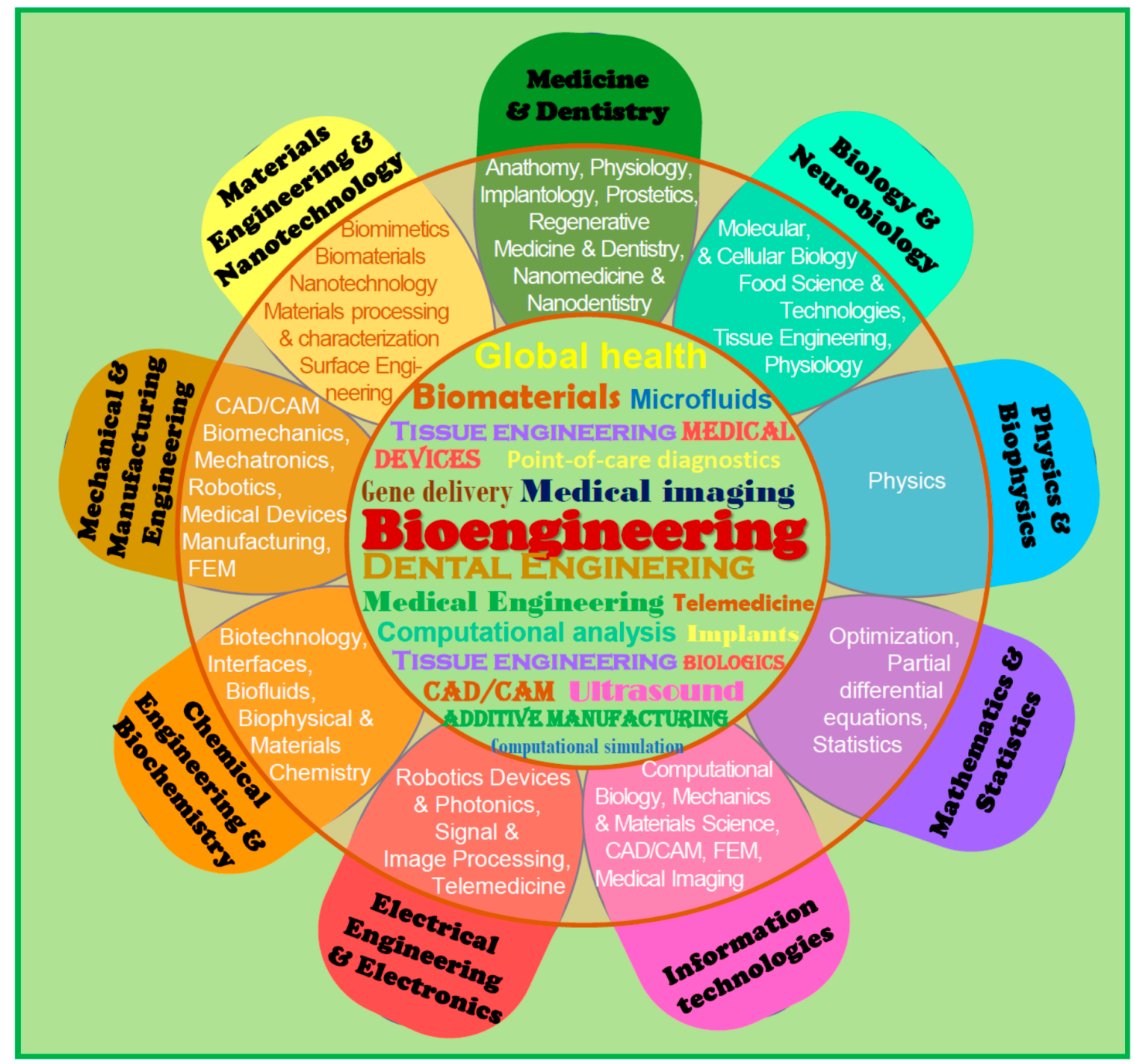

Figure 13. The flower of bioengineering showing a scheme of the scope of its interests, where each petal illustrates the interdisciplinary contribution of each discipline; the central circle corresponds to selected bioengineering problems; the middle circle determines the contribution of the detailed issues of each component disciplines. 
Bioengineering tasks pose special challenges for the engineering staff of many specialties indicated in the diagram, which should meet, on the one hand, the expectations of doctors serving the avant-garde areas of medicine, regenerative dentistry, tissue engineering and corresponding to the challenges related to patients health, and on the other hand, fulfill the principles of the current development stage of Industry 4.0 [133-139] is very responsible research. According to complex and advanced original technologies, the most avant-garde trends concern the offering of personalized medical devices manufactured according to the patient's individual anatomical features and newer and newer biomaterials used in implantable devices. These issues are among the most avant-garde and constantly developing engineering problems of great importance for the development of medicine and dentistry and have been the authors' scientific interest for many years [9,140-159]. The collaboration of biomedical and dental engineers with doctors in patients' service and assisting them in removing or at least alleviating the disease's effects obligates doctors and engineers with a specific ethical approach. As part of the obligation to systematically expand their knowledge, this cooperation imposes on doctors to follow the latest scientific achievements to use them for their own patients. The far-reaching dependence of modern medicine and dentistry on technical progress and engineering achievements requires doctors to trust engineers and rely on their experience and knowledge and their entrepreneurship and initiative. From this, these particular ethical requirements arise, which must be met by every engineer working with a doctor, even though he/she is not officially obliged to take any oaths. However, this is an undisputed and unconditional moral imperative of an engineer. It is a schematic view in the form of the oppression of two hands symbolizing two different communities' cooperation, shown in Figure 14 [57,58].

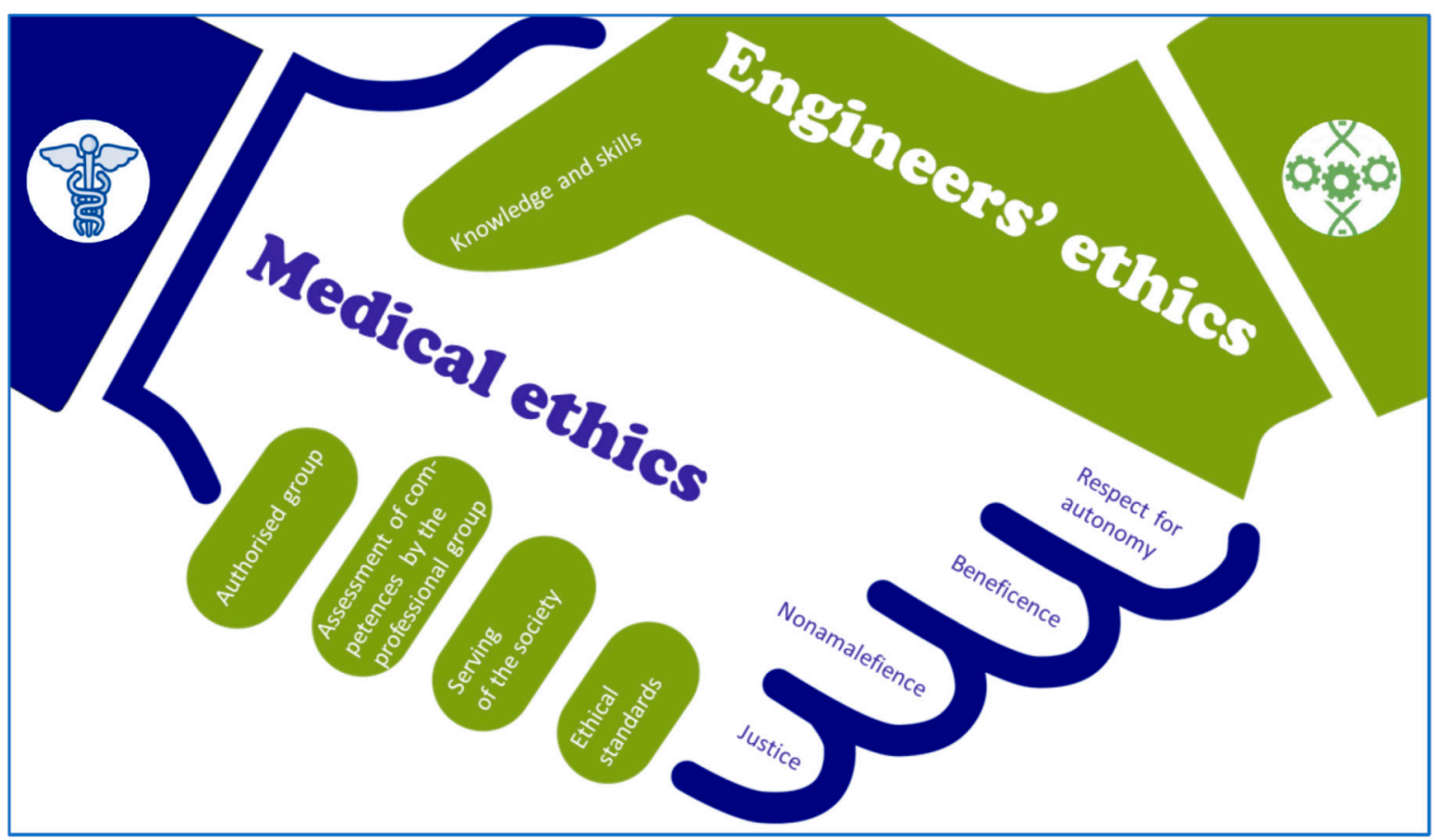

Figure 14. Diagram of the coincidence of ethical principles of the medical and engineering communities necessary for implementing therapeutic tasks requiring cooperation with bioengineers.

The requirements for this cooperation include the provision of advanced medical devices using the latest technology achievements, but also often, e.g., in the case of dentistry, trauma surgery, regenerative medicine, individual design and production of prosthetic restorations, implants, or rehabilitation devices personalized to the patient's anatomical features. It requires the use of extensive engineering knowledge in the field of modern design and manufacturing methods using computer-aided engineering works, including computer-aided design CAD and manufacturing CAM, computerization, robotization, and 
automation. It requires using the most advanced biomedical and other engineering materials and the most modern engineering technologies, including additive manufacturing and surface treatment. Although engineers generally do not participate in medical procedures involving patients, they are also guided by ethical principles [160-163] (Figure 14), which include a pentad, including improving specialist knowledge, achieving high competence, ensuring high standards, serving society in line with the ethos of the engineering profession, and designing and manufacturing products of high technical and utility values. The considerations are of professional ethics, which results directly from every person's internal imperative, which is a derivative of upbringing and worldview beliefs. Admittedly, many so-called ethical codes of various professional groups, but in fact, play a similar role to legal regulations. Sometimes the effect of such regulations coincides with the ethical imperative, but the motivations are completely different. Three orders are not mutually exclusive and can even complement each other. The motivation in each of them answers a different question. How to proceed is the ethical question. What people will say is a social category. What kind of punishment can be imposed is the legal order. Therefore, each code can be included in the second or even third of the groups mentioned above of regulations. On the other hand, the highest possible value is the inner conviction of the need to perform the duties properly. In the case of a biomedical or dental engineer, it is also a moral responsibility towards patients, despite the most frequent anonymity of the function performed by him/her in the process of treating patients.

However, the implementation of all avant-garde technical solutions is acceptable only when their use means an absolute risk that is less than the total benefits. In the latest technological solutions, sometimes, this rule should be exceptionally abandoned [164]. It will be an ethical tort, or even an offense, to avoid the latest technical solutions in clinical practice consciously.

A very wide range of medical products and devices is of interest to biomedical engineering (Figures 15 and 16). Due to the significant degree of possible health complications, the principles of manufacturing both medical products and devices are subject to strict legal regulations. For example, in the European Union, these issues are covered by the medical device regulation MDR and the in vitro diagnostic medical device regulation IVDR [165]. "Medical device' means any instrument, apparatus, appliance, software, implant, reagent, material or other article intended by the manufacturer to be used, alone or in combination, for human beings", instruments, bandages and splints, and treatment chairs and hospital beds. In turn, "in vitro diagnostic medical device means any medical device which is a reagent, reagent product, calibrator, control material, kit, instrument, apparatus, piece of equipment, software or system, whether used alone or in combination, intended by the manufacturer to be used in vitro for the examination of specimens, including blood and tissue donations, derived from the human body."

Examples include pregnancy tests and blood glucose monitors. Some products called borderline ones are difficult to put into any of these groups. For example, it is possible to specify medicated surgical dressings or head lice products. Specific legal regulations similar to those relating to medical devices also apply to aesthetic products, including non-corrective contact lenses, liposuction equipment, or equipment intended for brain stimulation. The classification of both basic groups of medical devices is risk-based, which dictates the appropriate conformity assessment procedures. It also applies to research works, when in a significant number of cases, the Bioethics Committee's consent is required. Class I, and as appropriate devices do not require release procedures. However, some require approval by a notified body for parts of the manufacturing process related to sterility or metrology if the medical device contains sterile products or has a measuring function. In all other cases, it is necessary to perform appropriate and prescribed by law con assessment activities, referred to as General Safety and Performance Requirements. These procedures are handled by the proper Competent Authority Institutions designated in each country. 


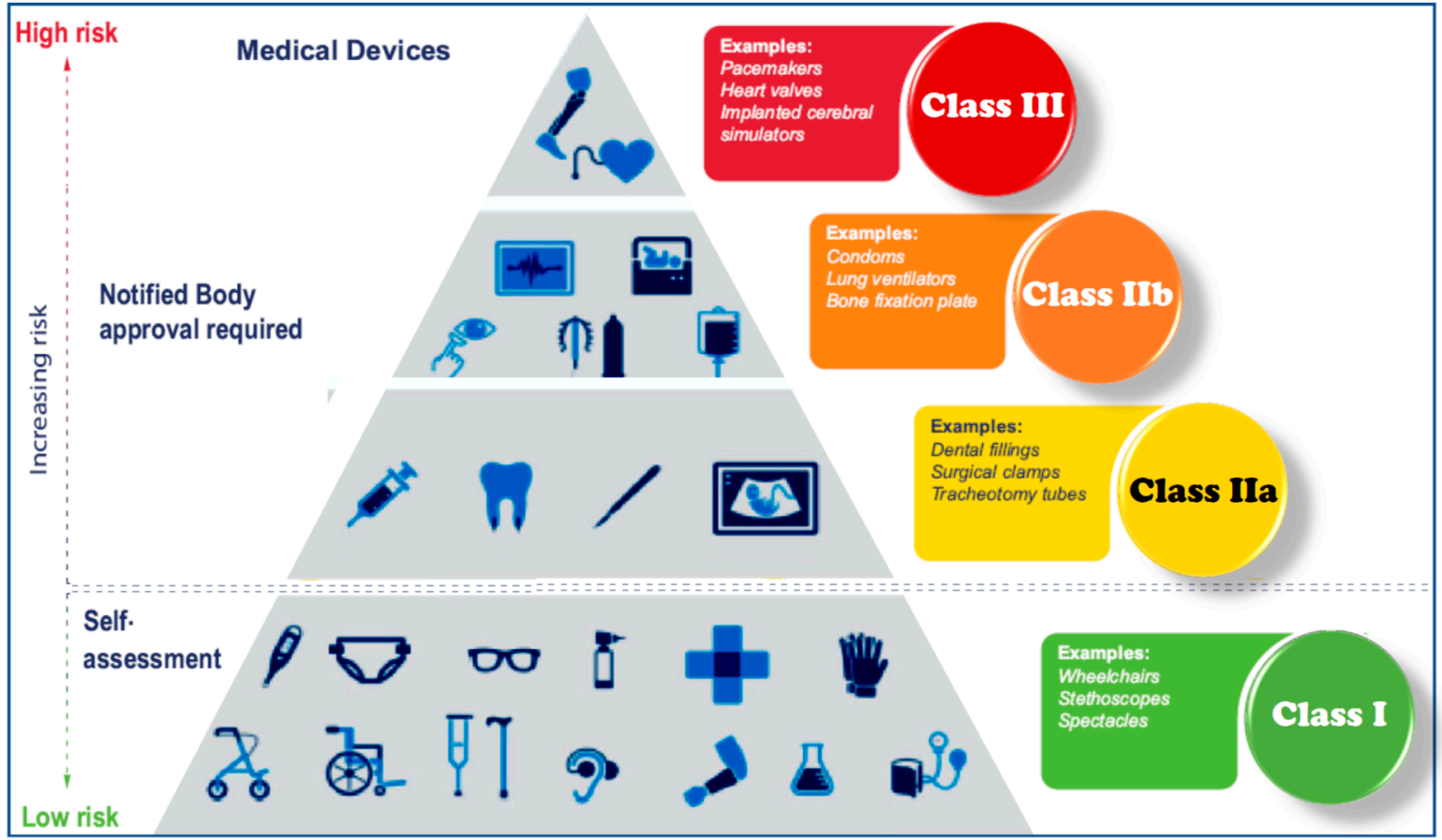

Figure 15. Scheme of the general classification of medical devices depending on the application risk.

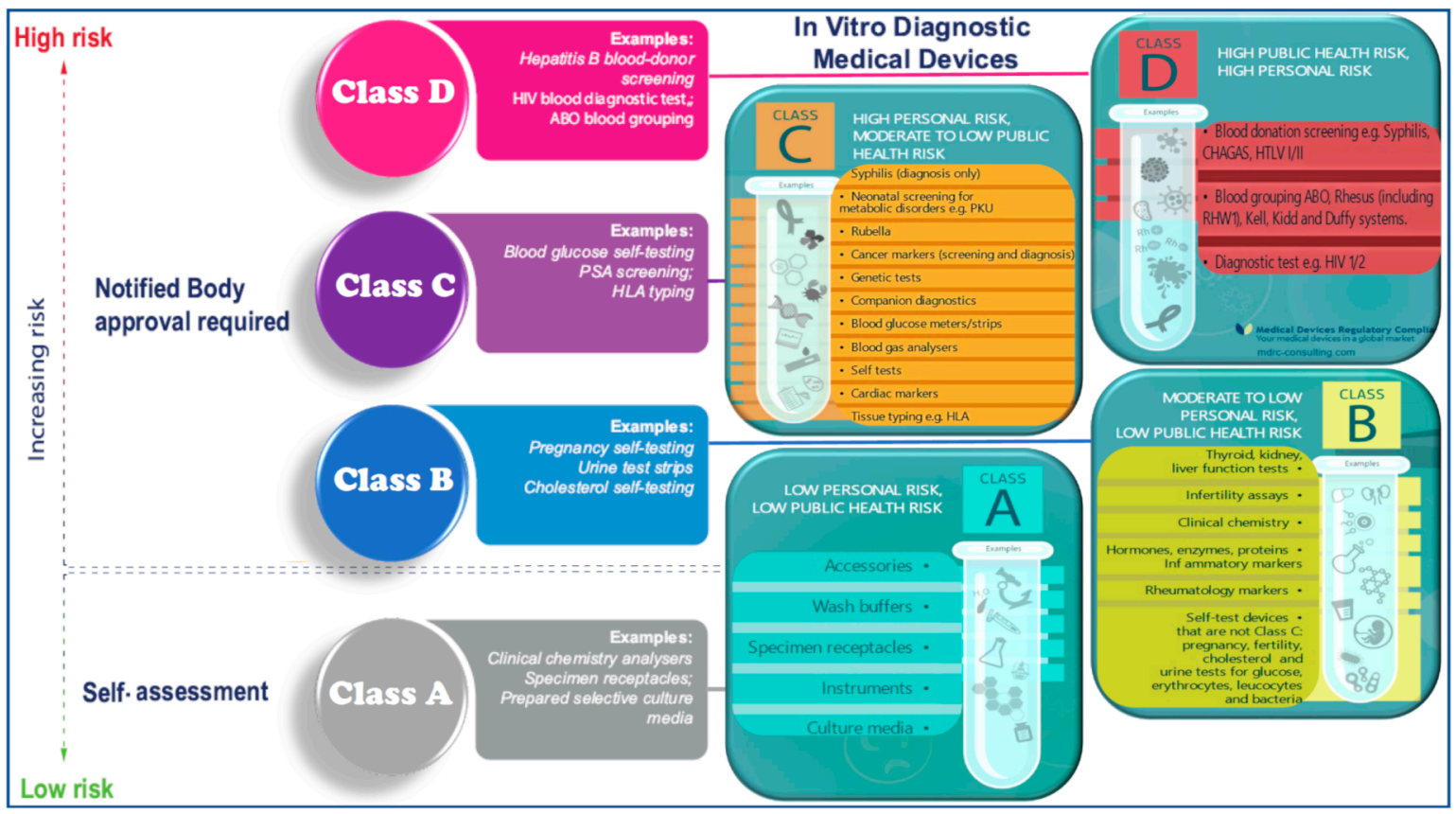

Figure 16. Scheme of the general classification of in vitro diagnostic medical devices depending on the application risk.

Figure 17 shows examples of artificial organs, implants, and other medical devices. 


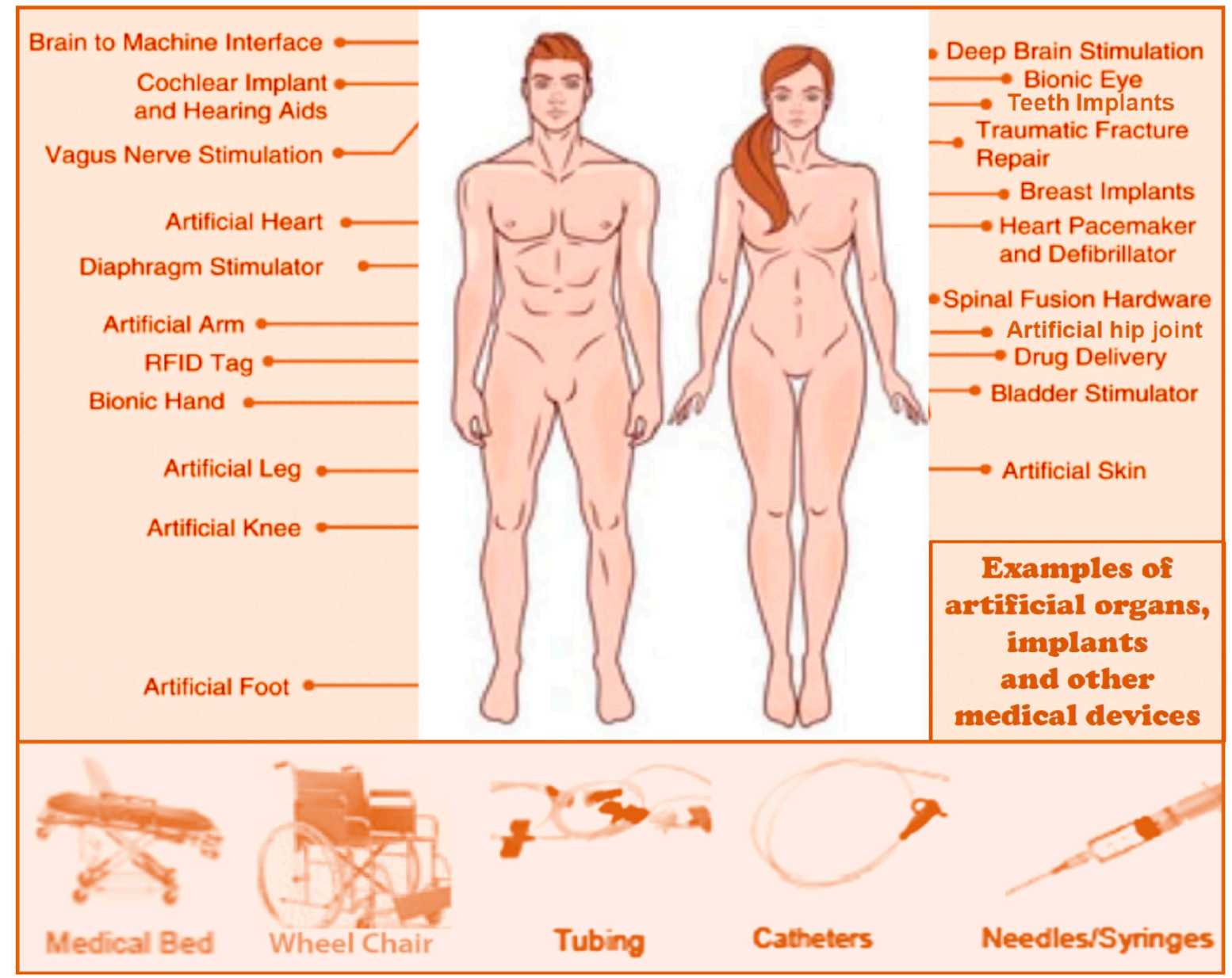

Figure 17. Examples of artificial organs, implants, and other medical devices to replace various tissues and organs of the human body and medical care.

The historical development of manufacturing processes is part of the development of human material culture. The most popular industrial development concept developed in Germany, popularized globally, and described in numerous authors' own works [133,134, $136,145,166-232]$. The first step in this development of Industry 1.0 and the beginning of the industrial revolution was the steam engines' introduction at the end of the 18th century. In the classic model of the current stage of Industry $4.0[133,134,136,179,185-187,190-193,196-$ 200,205-209,211,213,220,233,234] nine basic technologies described in the literature are indicated [133,134,166,167,174,178-233,235-238] creating cyber-physical systems (CPS), making smart decisions based on real-time communication with people, machines and sensors. It turned out that this model is one-sided and requires a significant extension, not just complex cyber-physical systems and very advanced tools and information systems. This model, however, gives the erroneous impression that the progress concerns only CPS systems, which is not true because it is necessary to include engineering materials, technological manufacturing processes, and technological machines in this model [133,134, 136,168-172,183,239] (Figure 18). Far-reaching simplification also boils down to limiting technological issues only to additive manufacturing. As the only technology included in the classic Industry 4.0 model cannot be considered competitive to other technologies necessary to use in many product manufacturing processes. 


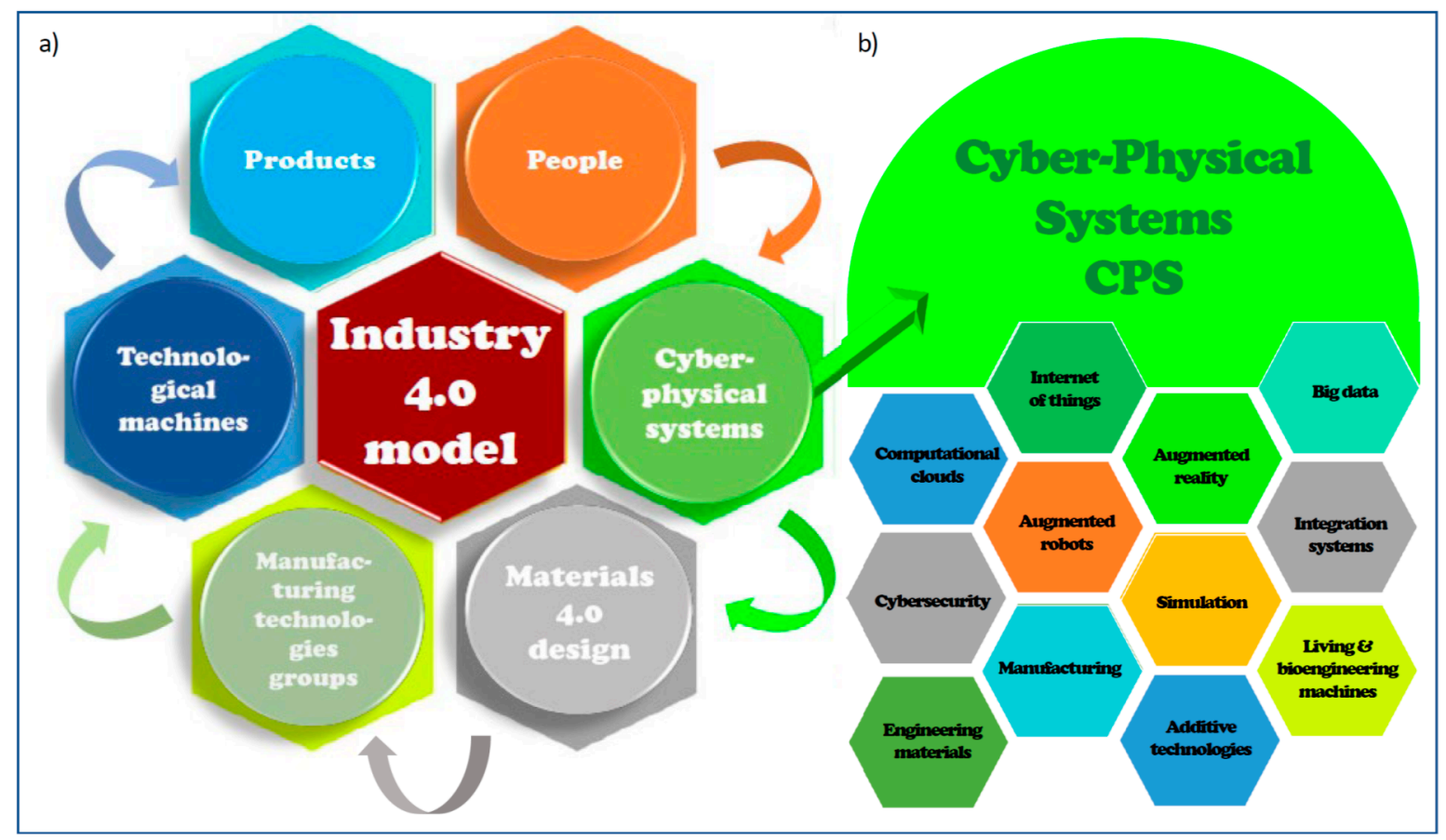

Figure 18. Diagram of (a) augmented elements of the holistic Industry 4.0 model; (b) extended scope of cyber-physical systems.

Manufacturing products is a technological process organized according to a welldesigned plan, requires the use of engineering materials, as well as energy, capital, people, various machines, and is a comprehensive activity bringing together people who carry out different professions and activities, using different machines, equipment, and tools, to a varying degree automated, including computers and robots, most modernly included in the rules of the Industry 4.0 stage. The purpose of production is each time to satisfy the market needs of customers, following the developed strategy of the company or organization involved in the production, using the available possibilities and devices. The technical aspects of introducing a given product to the market, including medical devices, by the manufacturing organization relate to industrial design, engineering design, production preparation, manufacturing, and servicing (Figure 19).

Thus, in introducing products to the market, three main spheres can be selected, i.e., marketing and sales, product development, including the design of the product, and manufacturing [240]. The product design phase is concerned with industrial design, engineering design, and production preparation. Engineering design, in which the design of the production system and product design can be mentioned, is not an isolated activity because it affects all other phases of introducing a given product to the market. It is also dependent. Modern engineering design of products is a complex process, covering three equally important and inseparable and closely interrelated and complementary areas of activities related to material design, structural design of product forms, and technological design of product manufacturing, in a wide range including, inter alia, materials processing technologies. The basic premise is the $6 \times \mathrm{E}$ (expectations) rule $[133,136,241]$. The functional features of the products expected by the customer will be ensured if the expected engineering material is used for their production, processed with the use of technology with the expected quality, to obtain the expected shape of the final product with the expected structure and expected mechanical and functional properties. New engineering materials and manufacturing processes are subordinated to the customer's needs and the products needed functions, including medical devices. The material design methodology shaped in this way is associated with numerous activities related to the modeling and simulation of manufacturing processes and the prediction of the operational properties of materials, the development of safe material technologies and products composed of nanostructured 
elements, the standardization of research on the properties of materials, especially nanostructured ones, and the development of a methodology for predicting the behavior of new materials during operation. The basis of material design in any practical application is multi-criteria optimization related to belonging to one of the main groups of engineering materials or the group of natural materials, with the chemical composition, manufacturing conditions, operating conditions, and the method of removing material waste in the post-use phase, as well as price conditions related to the acquisition of materials, their processing into products, the products themselves, as well as the costs of post-production and post-exploitation waste disposal, as well as modeling all processes and properties related to materials. The most advanced stage of selecting materials understood in this way is defined as Material 4.0 [133-136,173,241], together with the possibility of doing virtual experiments under the idea of "digital twins".

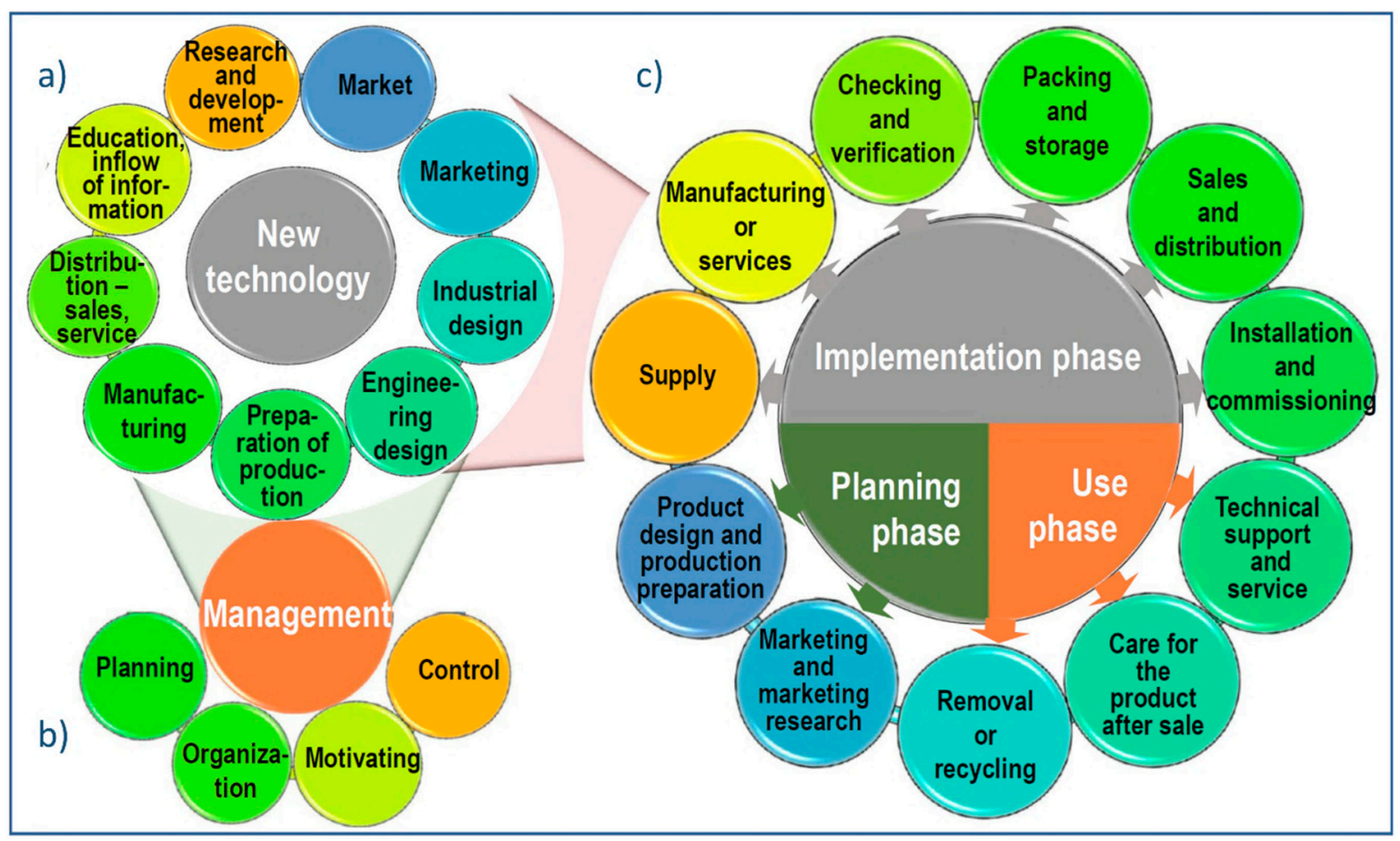

Figure 19. Diagram of the (a) interdependence of factors related to the introduction of a new product and a new technology to the market, (b) with production management, (c) and the product life cycle included in the quality loop.

Designing and manufacturing products with all expected utility values and properties required for technical reasons is the basic goal of all engineering activities. Engineering design is related to determining the shape of a product and its components to ensure the appropriate operation mode, taking into account the costs. The designed product must meet the parameters fully corresponding to its intended functional features, shape requirements, and dimensional tolerances. Apart from the list of materials and production methods, the project must consider the consequences and risk of damage to the product due to foreseeable but probable misuse or imperfection in the manufacturing process. Possible consequences of a product failure affect the assessment of the significance of its assumed reliability. The economic considerations do not impose overly high requirements on reliability if there is no injury to people and no significant loss to occur due to damage to this product during use. Each version of the shape of the product imposes material requirements, which may include the relationship between the stresses associated with the shape of the product and its load and the strength of the material. Process change can change material properties, and some product shapes and material combinations may not be feasible with some technological processes. Deterministic or probabilistic methods can determine the relationship between the requirements for the shape of the product and the 
material's characteristics. In deterministic methods, calculations are based on nominal or average values of stresses, dimensions, and strength. Also, appropriate safety factors are used, whose task is to consider the expected variability of these design parameters. In the probabilistic approach, individual parameters are assigned a proper variability distribution. Using these distributions and an acceptable margin of safety is possible to determine either the minimum adequate critical sections or the minimum strength of the product's key elements to be designed. It is then necessary to use more sophisticated calculation methods, resulting in a more compact structure of elements, requiring a smaller material mass. Regardless of the approach to the engineering design of product elements, the influence of notch and stress concentration should increase the damage's sensitivity. The cyclic loads, high or low-temperature operation and the presence of general corrosion or stress corrosion cracking are special hazards that must be taken into account in the material selection process.

In engineering design, quality management issues should be taken into account. Due to the disastrous consequences of placing defective products or services on the market, in each production process very important should be quality assurance. The constantly increasing quality requirements set by customers force manufacturers to focus their efforts in a pro-quality manner. Nowadays, the problem does not come down to detecting product defects but avoiding them or eliminating them during the manufacturing process. Therefore, it requires manufacturing and offering products for sale and services meeting the requirements of high and repeatable quality, modern, delivered on time, and provided at an affordable and competitive price. The conditions mentioned above pose certain expectations at the engineering design stage concerning the required quality of production and products. Failure Mode, Effect, and Causes Analysis (FMEA) is used more and more as an analytical method for both product design and manufacturing to avoid occurring or potential product defects. It is especially recommended in the development and production of a new product because it allows for identifying possible defects in advance, which enables their elimination as a result of applying preventive measures, even before the production of, for example, a new product [121,242].

In addition to the manufacturing processes, the engineering design process itself requires quality assurance, which is why it is planned, controlled, and supervised by clearly and comprehensively established goals, proper documentation of each stage of design, as well as by checking the results of activities by highly qualified staff. Such actions aim to change the previously common situation, where the design product was verified during the production or even operation of the product. Most errors and defects were revealed. Therefore, the applicable organizations and engineering design methods should reduce the number of design errors, detect them, and eliminate them already at the design time. Planning activities related to engineering design consist of dividing the process into stages, determining the design process points where project reviews and verifications are planned, linking and coordinating component activities, and determining the group of employees implementing the project and the means of enabling this activity. is essential to consider the complete product lifecycle when designing a product from the concept development stage. Due to the identification of threats related to the prospect of disturbing the ecological balance as a result of human activity, following the concept of sustainable development, ensuring the necessary balance between the interests of modern and future generations, the goal of which is a man and not material goods. Sustainable development on a global scale is the sum of local events, which requires searching for detailed design and technological solutions. Hence the emerging terms of sustainable technology or sustainable product or sustainable management. The fundamental role of material and technology design in the product life cycle's ecological course directly follows. It deals with two aspects: the market duration cycle and the technical duration cycle. The quality loop (Figure 19c) covers all phases of the project that enable shaping the product quality, from the initial determination of its parameters and description of needs to the final 
fulfillment of the recipient's requirements. Quality issues in the production, distribution, and consumption processes of a product must be considered comprehensively.

The product should be designed considering the possibility of reusing its elements that are not subject to wear or recovering the materials from which it is made. The re-use of these elements and materials reduces the consumption of raw materials and allows you to save energy needed to obtain engineering materials, e.g., metal from ore. The energy consumption is significantly reduced when using materials that do not require heat treatment with good strength properties. During operation, the energy consumed also has a significant share in the cost of a product's full life cycle [121,242].

The production of many medical devices, including orthopedic implants and standard mass-produced dental implants, in terms of organization, does not differ in any way from the production of other products, e.g., household appliances or cars. A smart factory is the basis of the modern manufacturing process [204,206], with a high degree of automation, robotization, and computerization based on the principles of Industry 4.0 for the development of industrial production (Figure 20).

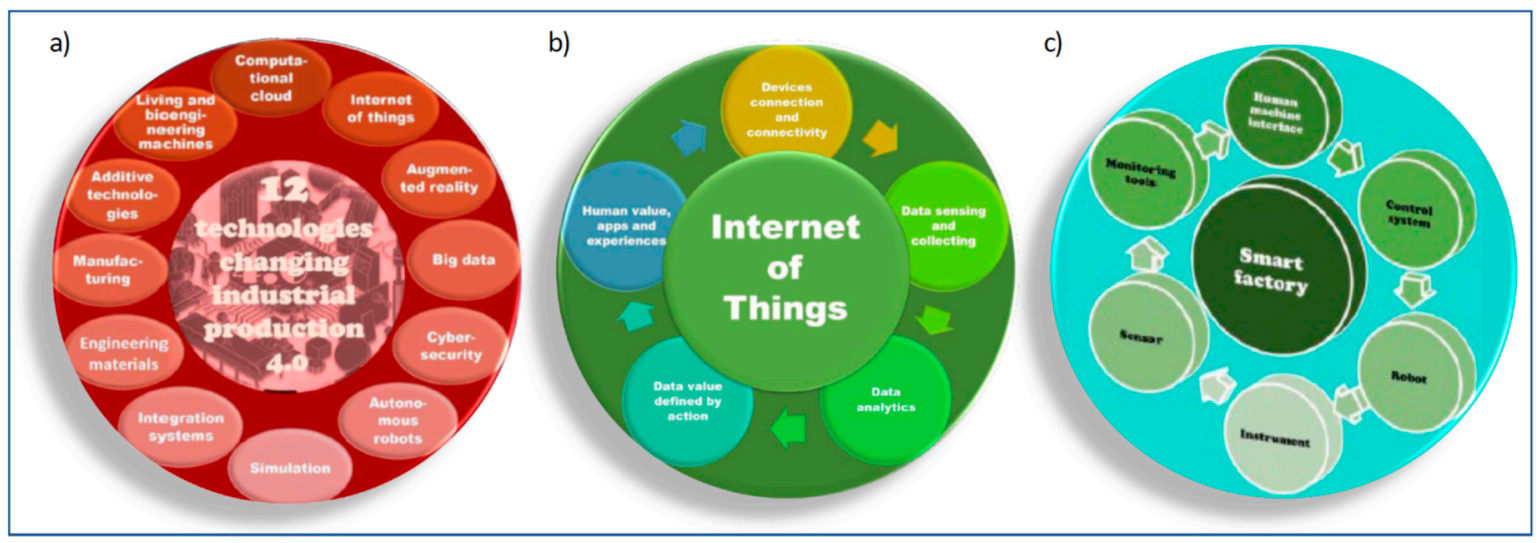

Figure 20. Diagram: (a) twelve technologies underlying the assumptions of Industry 4.0; (b) the Internet of Things; (c) interrelationships between smart elements of the Industry 4.0 system inside the Smart Factory.

Smart factories producing smart products use the embedded cyber-physical system to create value and exchange smart data via smart grids. Intelligent decisions regarding both the conditions of production and the value chain are made due to smart cooperation and information exchange between people and machines using a set of smart sensors. The exchange of information is ensured by the collaboration of the Internet of Things, people, and services. Relationships between stakeholders, i.e., employees, suppliers, and customers, production devices, and products in the product life cycle, are realized due to the exchange of information located in a virtual network using the computing cloud $[190,191,211]$. The smart data collected in this way influences the actuators in real-time due to which they change processes, products, and people's reactions. According to the augmented holistic model of Industry 4.0, twelve key technologies are used, including cyber-physical systems and engineering materials, and a full set of manufacturing technologies and machines, including additive technologies (Figure 20). Undoubtedly, this approach concerning the discussed problem should be considered Bioengineering 4.0, as a detailed case of Industry 4.0. On the other hand, this requires strict adherence to the achievements in this area in all phases of the manufacturing process, starting from market analysis, through industrial design, engineering design, production preparation, manufacturing, distribution, and maintenance, as well as removal or processing in the post-consumer phase of the product life cycle (Figure 21). 


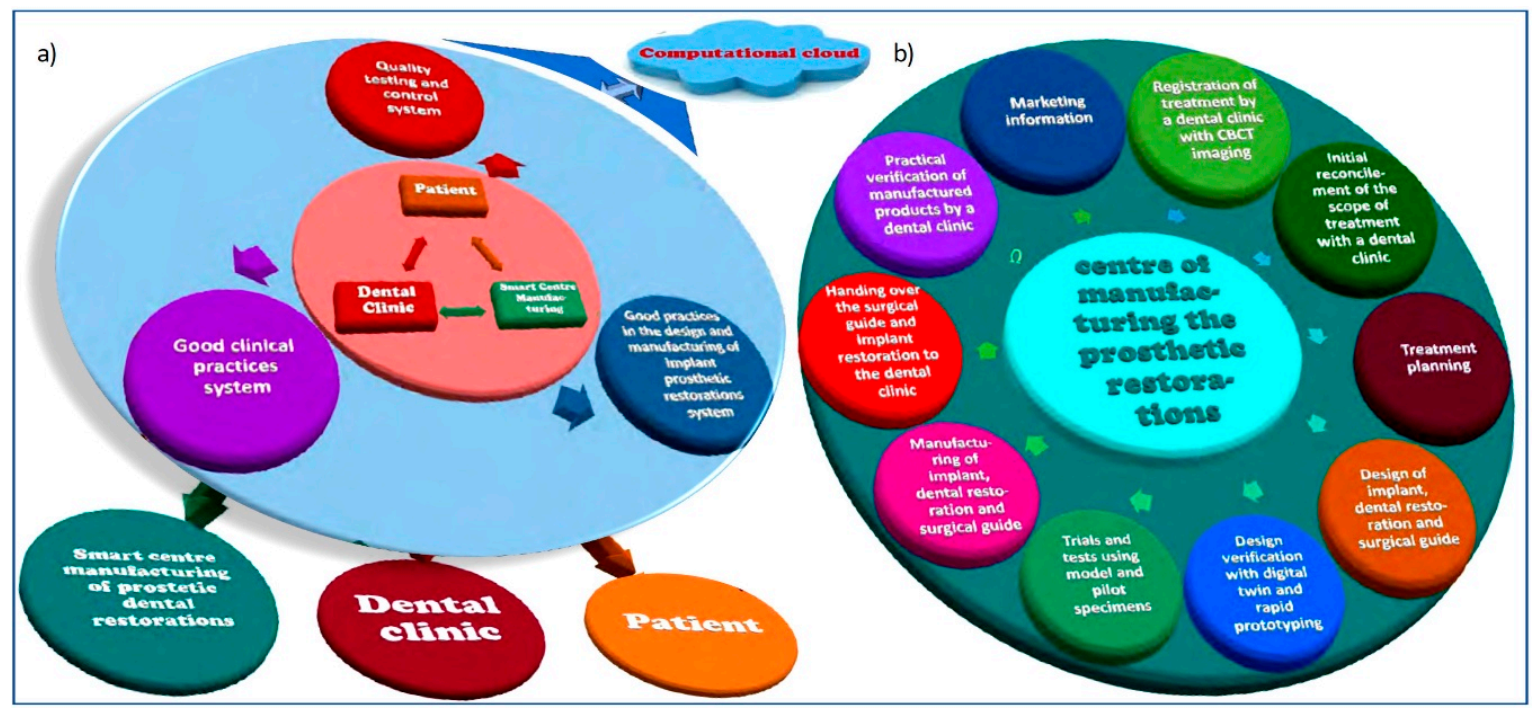

Figure 21. Diagram (a) relationship between the patient's expectations, design, and manufacturing capabilities of the center for the manufacture of dental prosthetic restorations and (b) the medical tasks of a dental clinic according to the concept of Dentistry 4.0 .

A quite different situation is in the production of fully personalized implants and prosthetic restorations, which usually occur during implantological and prosthetic treatment in dentistry. In this case, the implementation of the achievements of Dentistry 4.0 corresponding to the current stage of Industry 4.0 development takes place in the center of manufacturing of prosthetic dental restoration, cooperating directly with the dental clinic. Figure 21 shows the role and the most important factors and tasks of the three basic subjects participating in modern implant prosthetic treatment. In the previous historical stage of Dentistry 3.0, the dominant achievement was improving conservative dentistry's effectiveness and disseminating X-ray images in diagnosing the dental condition [243]. The noticeable effects at the stage of Dentistry 4.0 corresponding to the smart factory standards include 3D imaging with the use of cone-beam computer tomography CBCT, data manipulation, and cloud computing, and above all, the use of computer-aided design CAD and manufacturing CAM methods for the production of personalized prosthetic restorations and it is not only by milling with the use of center numerically controlled CNC but above all by additive manufacturing AM, the so-called 3D printing technology. The numerous benefits include improved oral state and a significant reduction in the total time of medical procedures, in some cases from several months to one day, after prior diagnosis with CBCT tomography [243]. The benefits also include reducing manufacturing costs and the overall costs of implant-prosthetic treatment and the costs of the dentist, medical and engineering staff, and the patient's time $[133,134]$. The benefits of Dentistry 4.0 also include the integration of supplier and patient networks (Figure 22).

As the manufacturing centers for prosthetic restorations belong to micro or small enterprises, and the production is unique and personalized, automated guided AGVs are usually not used. Still, smart entry and exit logistics are applied. These centers collaborate with numerous dental clinics, from where they receive electronic data on the diagnosis of individual patients, including СВCТ photos, via the network or cloud computing. On this basis, prosthetic restorations, models, and templates are designed and manufactured through computer-aided design CAD and production planning CAPP with the use of centers numerically controlled $\mathrm{CNC}$, machines for additive manufacturing, e.g., the selective laser sintering SLS method, as well as surface coating, including internal surface coating, by atomic layer deposition ALD, often involving robots. A cyber-physical system enables creating a value chain. Sensor systems of manufacturing machines identify the factors of creating value and monitor manufacturing processes, and smart data activates the appropriate actuators. Prosthetic restorations from essence are personalized according 
to the principle of demand in every case so that a prototype is always produced. Still, it can be verified in virtual reality using the method of "digital twins". It is also possible to apply artificial intelligence and machine learning methods, which enable machines to be smart to react to various production situations.

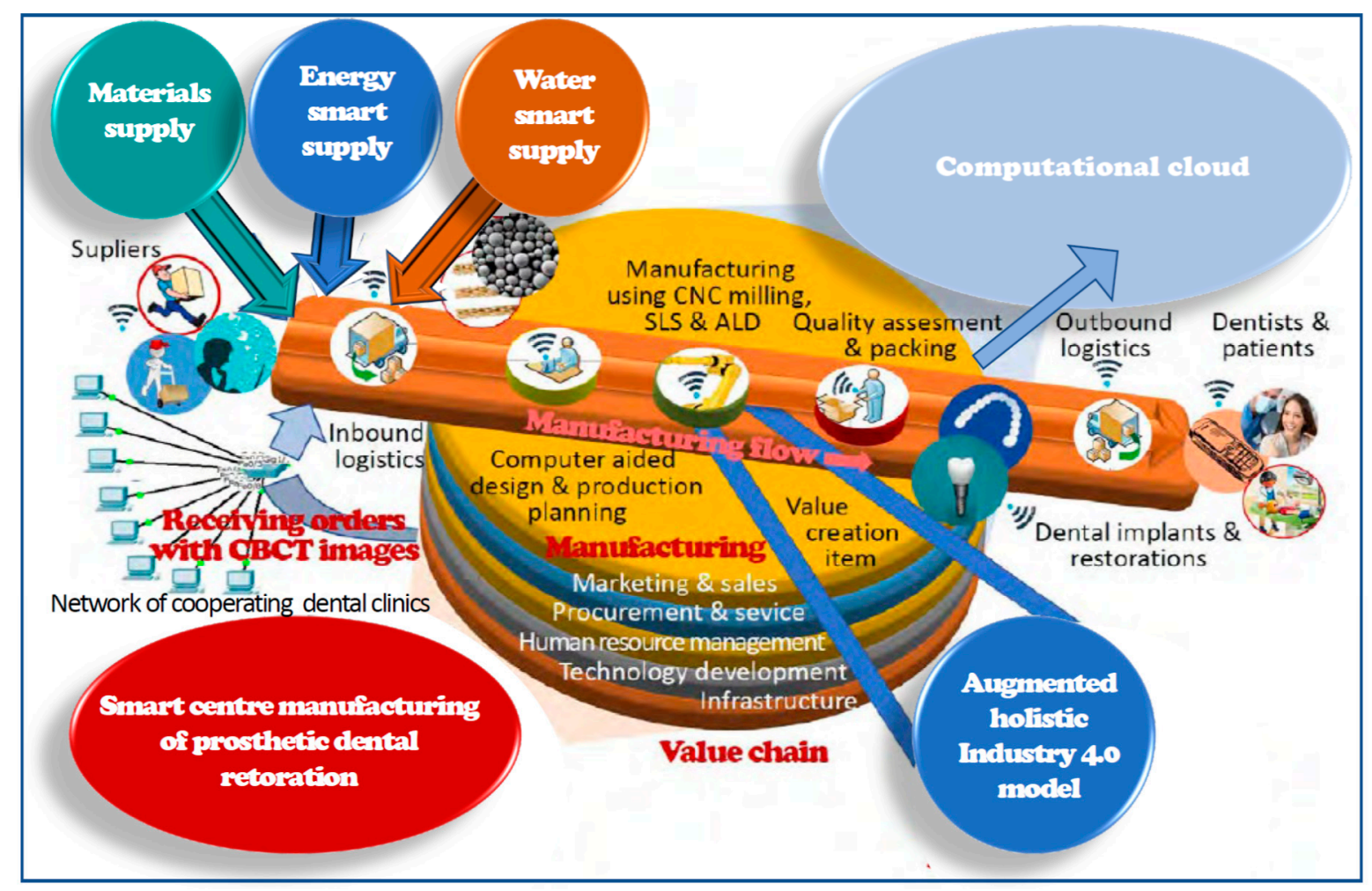

Figure 22. Diagram of an example technological line in intelligent centers produces dental prosthetic restorations, including horizontal and vertical integration.

Since ancient times, numerous medical procedures have been performed, including surgical ones requiring the use of various tools, documented, among others, by still in ancient Egypt recorded on artifacts and inscriptions discovered in Thebes and Rome and Greece. Even then, the relationship between technology and medicine became stronger with time. Many medical achievements have become possible only thanks to the possibilities offered by modern computer science, image analysis, electronics, and numerous medical devices, manufactured using the latest achievements of modern industry. From the point of view of the essence of the design and manufacturing processes, there is no difference between the production of an implant or dental prosthetic restoration and the production of a modern car or large passenger aircraft. The old, masterful approach has long gone down in history. The latest achievements of the current stage of the Industry 4.0 industrial revolution also apply to medical devices. The awareness of this fact must be disseminated among engineers dealing with bioengineering issues, and, importantly, among physicians who must have such advanced knowledge to be able to make appropriate demands with engineers cooperating with them. The extremely high and advanced level of engineering knowledge enables the achievement of such goals, but with full respect for the ethical principles that apply to all possible aspects of medicine. Biomaterials, without which any medical device cannot be made, play an extremely important role in this process.

Hence, this part of this paper focuses on the processes of designing and manufacturing biomaterials that ensure the advancement of medicine for a stage that is generally suggested name as Bioengineering 4.0. It should be noted that it is possible and necessary to use the idea of "digital twins fully". With extensive experiments in virtual reality, the costs and the 
number of practically performed laboratory and/or industrial trials can be reduced to a minimum.

\section{Examples of Application of Various Biomaterials in Medicine and Dentistry}

All products, including implants, implant-scaffolds, prosthetic restorations, and elements of medical devices, appliances, and apparatus, including electronic components in diagnostic devices and computer equipment used in medicine and dentistry, are produced of engineering materials. Without engineering materials, there are no products. Hence is the importance of engineering materials in any type of human production. In the context of health care, the group of biomedical materials [146,152,244-255], also often referred to as biomaterials, is of special importance. A biomaterial (biomedical material) is any substance that can be used at any time to supplement or replace the tissues of an organ or part of it to fulfill its function [150,242,256-258], provided that it is neither a drug nor a combination of synthetic or natural substances [258]. Biomaterials are characterized by the required biotolerance (biocompatibility), i.e., biological compatibility and harmony of interaction with living matter. Biotolerance (biocompatibility) is defined as biocompatibility. It means the harmony of interactions within living matter. The biomaterial with optimal biotolerance does not cause acute or chronic reactions or inflammation of the surrounding tissues. It does not interfere with the proper differentiation of the amputated tissue surroundings. The concept of biotolerance is often associated with preventing the initiation of toxicological and immunological reactions and the effects of tissue irritation [256]. Figure 23 shows the general classification of implants. A few criteria for the division of this group of materials can be adopted [152,250,253,259-280]. Therefore in this figure, a different graphic form was used for each criterion.

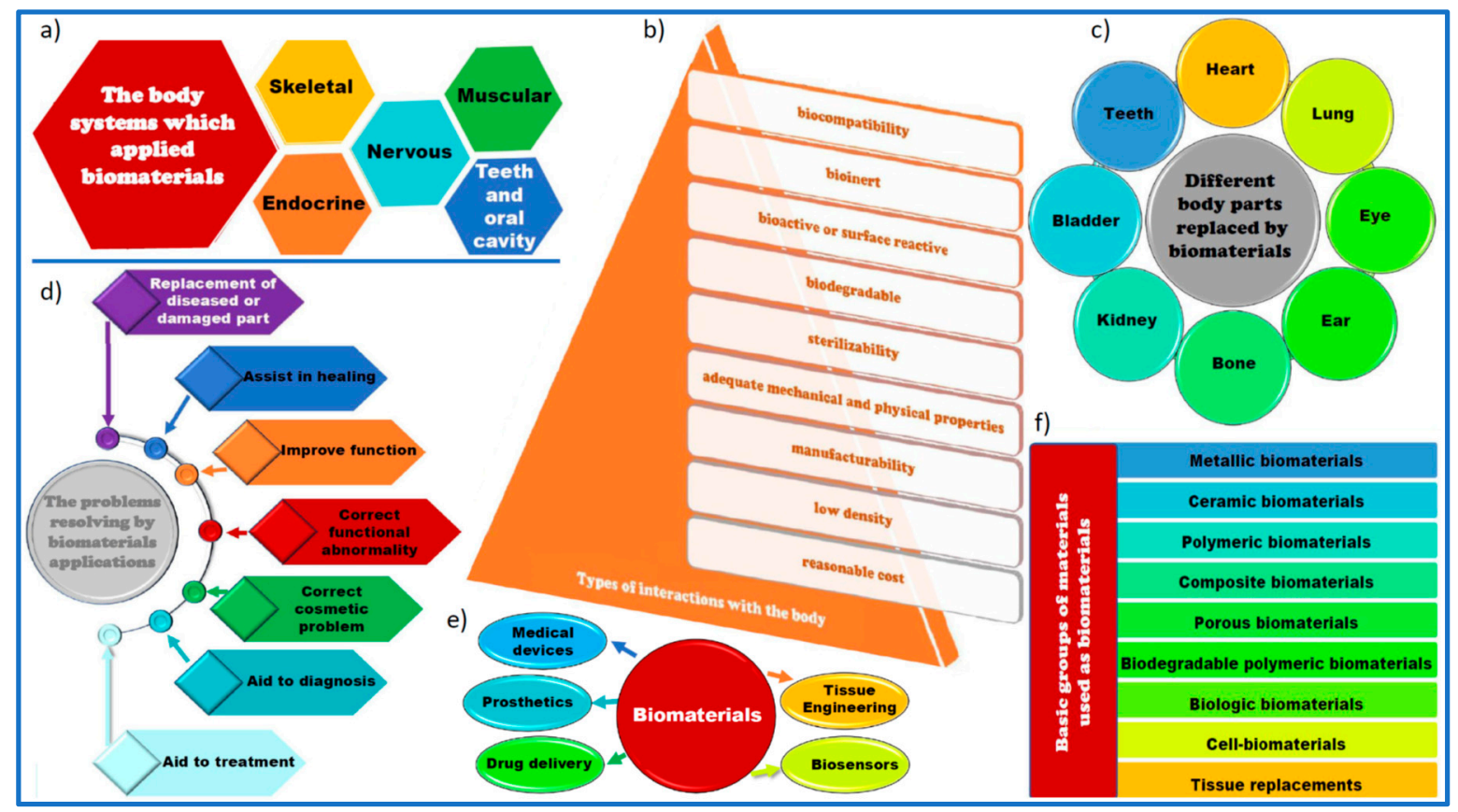

Figure 23. The general classification of biomedical materials according to various criteria: (a) the body systems which applied biomaterials; (b) types the interactions with the body; (c) different body parts replaced by biomaterials; (d) the problems resolving by biomaterials application; (e) applications areas of biomaterials; (f) basic groups of materials used as biomaterials.

This group of materials includes both metal materials, including pure metals and their alloys, and ceramic, polymer, and composite materials, and porous materials. Table 1 lists the most important criteria for the quality of biomaterials, including a set of requirements for implants [146]. 
Table 1. Examples of requirements for materials used for surgical implants.

\begin{tabular}{|c|c|c|}
\hline Mec & Technologic & Biotolerance \\
\hline $\begin{array}{l}\text { - } \quad \text { tensile strength, } \\
\text { - } \quad \text { yield point, } \\
\text { - } \quad \text { fatigue strength, } \\
\text { - } \quad \text { abrasion resistance, } \\
\text { - } \quad \text { stiffness, } \\
\text { - } \quad \text { plasticity (elongation, contraction), } \\
\text { - ductility (resistance to fracture). }\end{array}$ & $\begin{array}{l}\text { - ensuring the assumed quality of the } \\
\text { biomaterial, } \\
\text { ensuring the required quality of the } \\
\text { surface and the implant, } \\
\text { suitability of the material and } \\
\text { product for effective sterilization, } \\
\text { minimal manufacturing costs. }\end{array}$ & $\begin{array}{l}\text { - } \quad \text { reactions with tissues and body fluids, } \\
\text { - } \quad \text { stability of ownership: } \\
\text { - } \quad \text { physical, } \\
\text { - } \quad \text { chemical, } \\
\text { - degradation related to: } \\
\text { - local damage to the implant (harmful } \\
\text { - changes), } \\
\text { systematic corrosion effects (harmful } \\
\text { damage). }\end{array}$ \\
\hline
\end{tabular}

Biomedical materials usually come into direct contact with living cells, tissues, proteins, and even organs and organ systems. The criteria for classifying medical devices include [146]:

- contact or interaction with the body,

- contact with injured skin,

- contact with internal organs (e.g., heart, circulatory system),

- invasive nature with the holes in the body,

- implantation into the body,

- donating energy or substances to the body,

- period of application.

Table 2 presents the general classification of medical devices [146].

Biomedical materials are usually used to make the various medical devices listed in Table 2, which corresponds to the definition of engineering material. Sometimes, however, some chemicals, such as collagen injected to remove soft tissue defects, are used alone. Although they do not meet the definition of engineering materials, they are broadly referred to together with the relevant biomedical materials.

Technological progress has influenced the spread of biomaterials in various healthcare areas, including bioengineering, regenerative medicine, and tissue engineering. The authors previously presented their views and gathered extensive knowledge in this regard in previously published scientific books and academic textbooks [146,150,152,154,242,281]. Simultaneously, the biomaterials' usability and application versatility increased, regardless of the wide range of unique applications. There is a continuous development of novel methods for the controlled delivery and release of drugs. Smart biomaterials have been developed, including in some applications; they allow interaction with biological systems, such as bioactive molecules' transport. Smart biomaterials generate and transmit bioelectric signals analogous to those generated in original tissues, ensuring proper physiological functions. Piezo scaffolds are smart materials that play a significant role in tissue engineering. They stimulate signaling pathways and consequently improve tissue regeneration in the damaged area. The importance of partially or fully porous orthopedic and dental and craniofacial implants increases, including those with layers inside the pores, both biocompatible and preventing toxic spinal diffusion of certain metals, preventing metallosis. Porous structures stimulate bone growth around the implant and reduce the modulus of elasticity. Scaffolds enable the production of functional tissues. Powder metallurgy, 3D printing, and additive manufacturing are just some of the potential manufacturing techniques. Porous implants and implant-scaffolds, both metal, and ceramic, can be designed and manufactured using additive methods, the so-called 3D printing [139,282-291]. However, powder engineering is still offered wide possibilities, traditionally called powder metallurgy [137,138,152,292,293]. Additive methods are gaining importance among powder engineering methods applied to medical and dental devices made of biomaterials. These methods are comprised of others, in which metal and ceramic powders are used, in Figure 24. The method of procedural benchmarking was used $[119,121,138]$. The figure 
also lists the criteria for the potential and attractiveness of each technology. Marked as maroon-violet additive methods, including selective laser sintering and related methods, are located in the most favorable quadrant of the dendrological matrix-wide-stretching oak. Additive technologies concerning polymer materials used, among others, are also very possible on surgical templates and epitheses.

For these reasons, additive manufacturing technology is becoming more common concerning biomaterials and various medical devices, especially implants, both orthopedic, surgical, and dental [142,294-314].

Table 2. The general classification of medical devices.

\begin{tabular}{|c|c|c|c|}
\hline $\begin{array}{l}\text { The Main Criterion } \\
\text { for Classification }\end{array}$ & $\begin{array}{l}\text { Medical Device } \\
\text { Groups }\end{array}$ & $\begin{array}{l}\text { Medical Devices } \\
\text { Subgroups }\end{array}$ & Comment \\
\hline \multirow{3}{*}{$\begin{array}{l}\text { period of use of } \\
\text { medical devices }\end{array}$} & $\begin{array}{l}\text { transient } \\
(<60 \mathrm{~min})\end{array}$ & & \\
\hline & $\begin{array}{l}\text { short-term } \\
(<30 \text { days })\end{array}$ & & \\
\hline & $\begin{array}{l}\text { long-term } \\
(>30 \text { days })\end{array}$ & & \\
\hline \multirow{10}{*}{$\begin{array}{l}\text { degree of } \\
\text { invasiveness }\end{array}$} & \multirow{2}{*}{$\begin{array}{l}\text { invasive devices } \\
\text { (penetrating deep into } \\
\text { the body through an } \\
\text { opening in the body or } \\
\text { its surface) }\end{array}$} & surgical & $\begin{array}{l}\text { as a result of a surgical procedure, they are introduced } \\
\text { inside the body or under its surface }\end{array}$ \\
\hline & & implanted & $\begin{array}{l}\text { intended to be completely introduced into the body or to } \\
\text { replace the epithelial surface or the surface of the eye as a } \\
\text { result of a surgical intervention }\end{array}$ \\
\hline & \multicolumn{3}{|l|}{ surgical instruments } \\
\hline & \multirow{3}{*}{ active devices } & medical & $\begin{array}{l}\text { their operation depends on the conversion of feed energy } \\
\text { other than directly generated by the body or gravity }\end{array}$ \\
\hline & & therapeutic & \\
\hline & & diagnostic & \\
\hline & \multirow{4}{*}{ Implants } & surgical & $\begin{array}{l}\text { placed in the intended place in the body by surgical } \\
\text { methods }\end{array}$ \\
\hline & & other & for example, needles, drains, filters \\
\hline & & $\begin{array}{l}\text { implanted } \\
\text { prostheses }\end{array}$ & $\begin{array}{l}\text { internal prostheses or endoprostheses that physically } \\
\text { replace an organ or tissue }\end{array}$ \\
\hline & & artificial organs & $\begin{array}{l}\text { replacing wholly or partially the function of one of the main } \\
\text { organs, often in a non-anatomical way }\end{array}$ \\
\hline \multirow{4}{*}{$\begin{array}{l}\text { a field of medical use } \\
\text { or a specific location } \\
\text { in the body }\end{array}$} & \multirow{4}{*}{ Implants } & orthopedic & $\begin{array}{l}\text { used to support, replace or supplement temporarily or } \\
\text { permanently bone, cartilage, ligaments, tendons or } \\
\text { associated tissues }\end{array}$ \\
\hline & & oral & $\begin{array}{l}\text { used to improve, enlarge, or replace any hard or soft tissue } \\
\text { in the mouth involving the maxilla, mandible, or } \\
\text { temporomandibular joint }\end{array}$ \\
\hline & & craniofacial & $\begin{array}{l}\text { used to correct or replace hard or soft tissues in the } \\
\text { craniofacial area except for the brain, eyes and inner ear }\end{array}$ \\
\hline & & dental & used to replace missing teeth \\
\hline
\end{tabular}




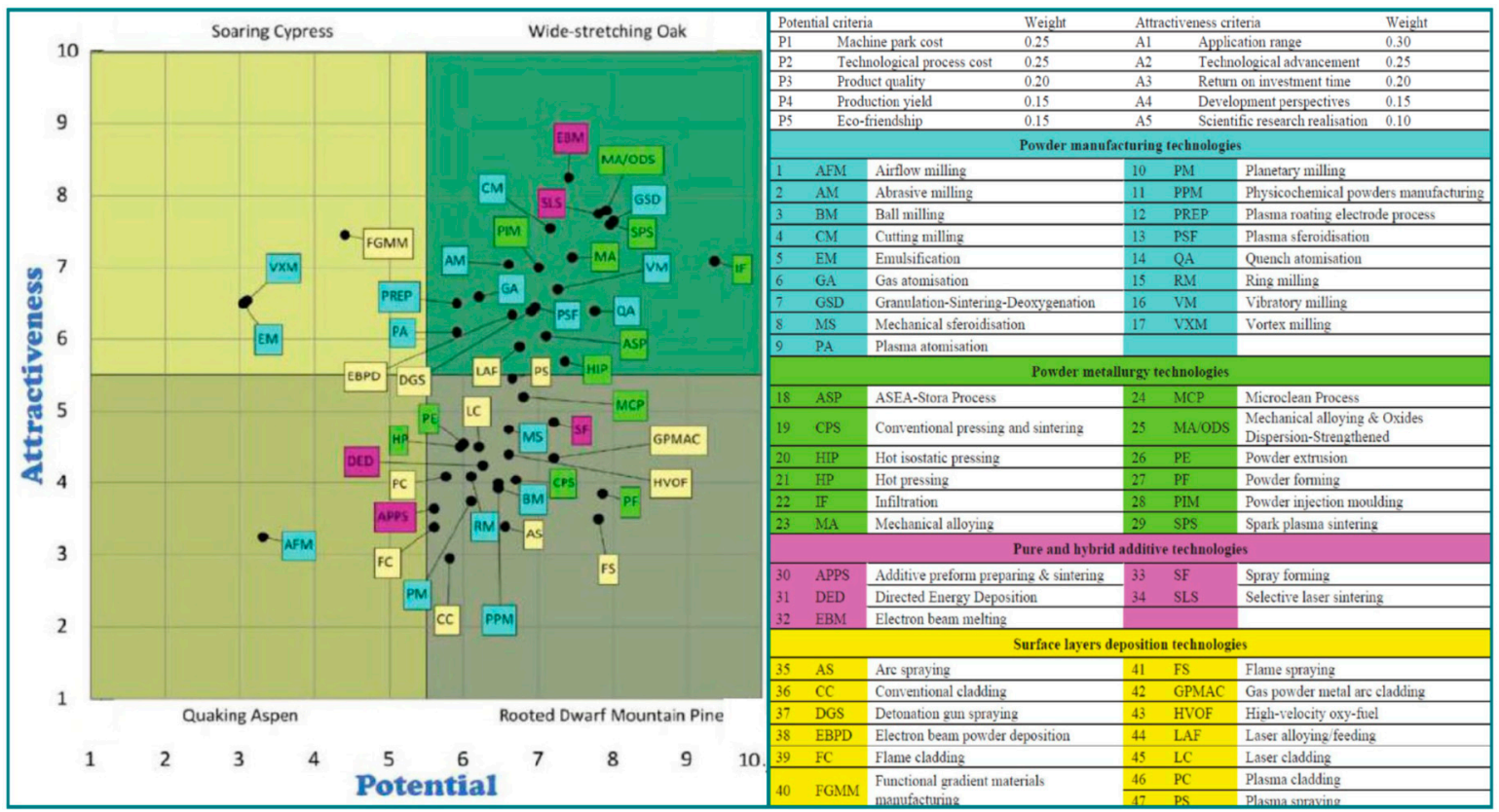

Figure 24. Results of the comparatist analysis of various powder engineering technologies for the application for medical device production.

Figure 25 shows an example of a full-arch dental bridge manufactured by selective laser sintering SLS from Co25Cr5W5MoSi alloy after individual design using CAD methods.

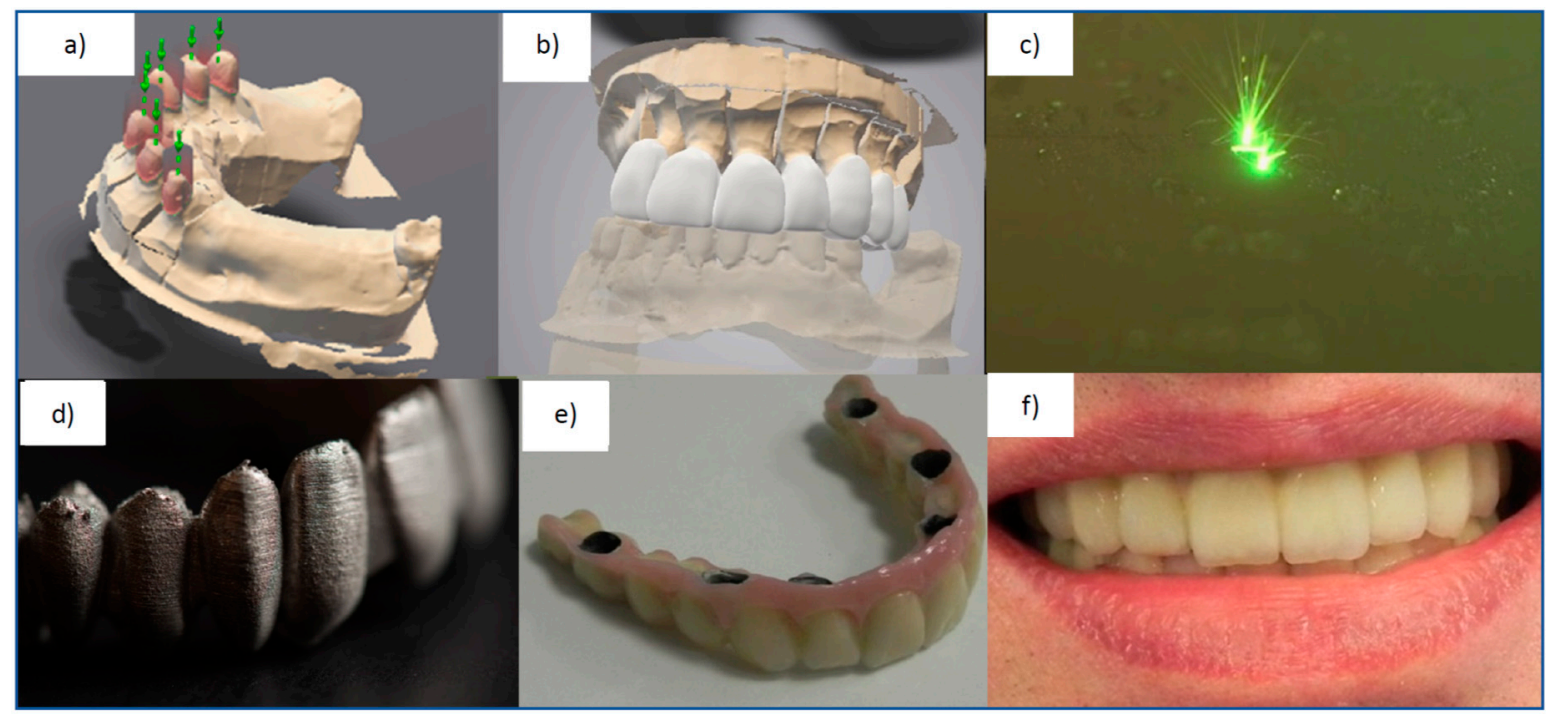

Figure 25. The examples of different stages of design and manufacturing by the selective laser sintering SLS of dental bridges from Co-Cr powders: (a) virtual tooth model and the verification of the parallelism of the pillars; (b) the finished foundation design for transferring from CAD to CAM; (c) selective laser sintering process photo; (d) the finished element after SLS; (e) the prosthetic restoration veneered with porcelain; (f) the bridge installed in the patient mouth.

Figure 26 shows the research results on selecting the conditions for selective laser sintering of Co25Cr5W5MoSi [291] and Ti6Al4V [139] alloys and their influence on the structure and properties of these alloys. These metal materials can be used in surgery and implantology, both in dentistry and orthopedics, and for other types of implants and prosthetic restorations. It turns out that the technological porosity depends, among others, on on the laser power density resulting from the interaction of the laser power and the diameter of the laser beam, as well as on the flow of protective gas and a dozen or so 
variables, it can vary from 0.06 to over $10 \%$, which causes almost 2.5 times differentiation in the strength of additive manufactured materials. Structural studies show that too low laser power density results in many powder particles did not melt during sintering. Sintering with the liquid phase's participation cannot occur, while diffusion processes do not occur [315-318]. Therefore, the technological process carried out in these conditions is far from correct.

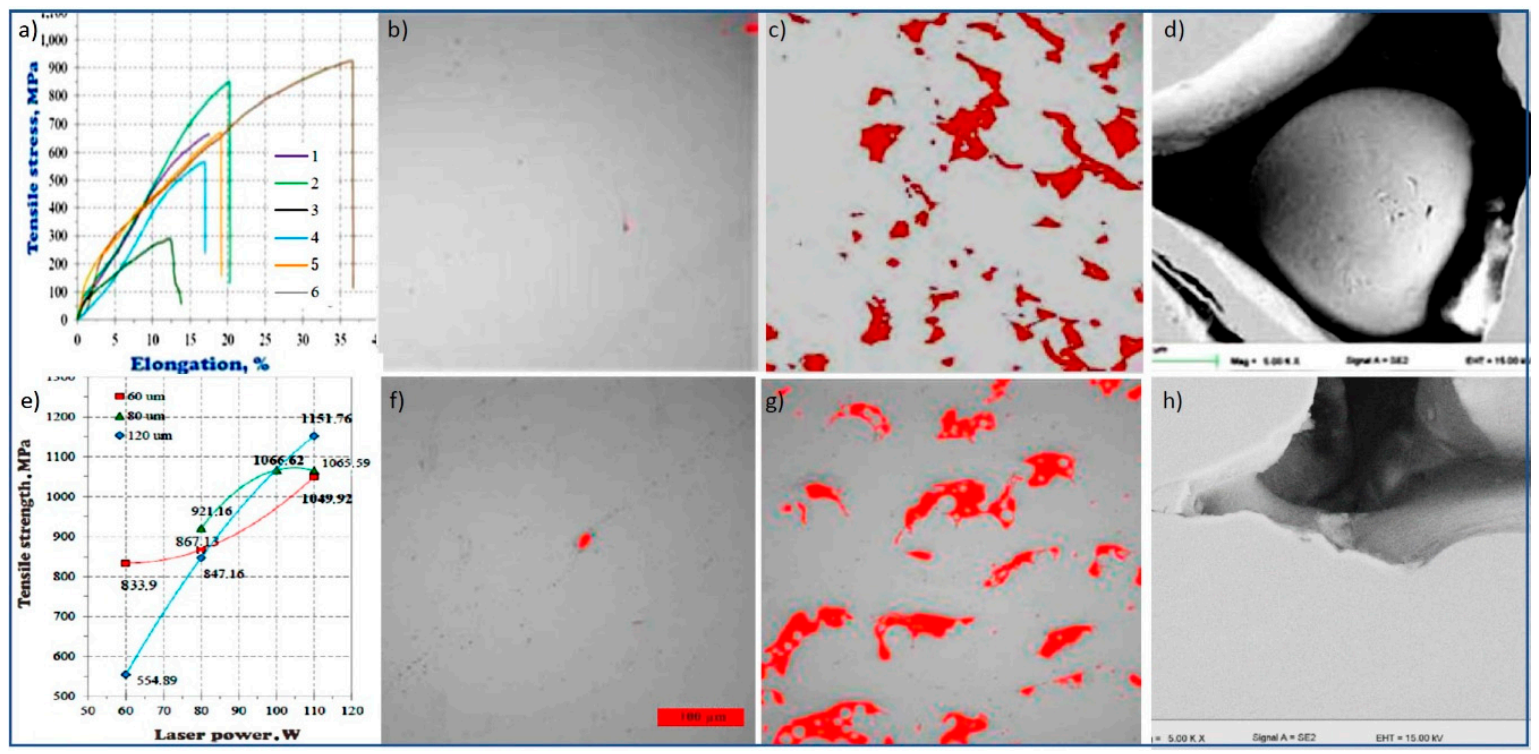

Figure 26. Influence of manufacturing conditions during selective laser sintering of powder on the tensile strength and structure of: (a-d) Co25Cr5Mo5WSi alloy; (e-h) Ti6Al4V alloy: (a) tensile strength (powder thickness $25 \mu \mathrm{m}$; laser power $105 \mathrm{~W}$; laser spot diameter $10 \mu \mathrm{m}$ (variant 4-80 $\mu \mathrm{m}$ ), scan speed $630 \mathrm{~mm} / \mathrm{s}$; laser beam width variant 1,4,5-120 $\mu \mathrm{m}$, variant 2,3-80 $\mu \mathrm{m}$, variant 6-100 $\mu \mathrm{m}$, allowance, variant 1,2,4.5-0, variant 3.6-10\%; variant 6-incorrect flow of protective gas); (b) porosity $0.08 \%$-option $3 ;(\mathbf{c}, \mathbf{d})$ porosity $9.87 \%$ —variant $1 ;(\mathbf{e})$ tensile strength; (f-h) porosity (f) correctly sintered alloy $0.06 \% ;(\mathbf{g}, \mathbf{h})$ under extremely inadequate conditions $10.53 \% ;(\mathbf{d}, \mathbf{h})$ pores resulting from incompleteness of liquid phase sintering; (b,c,f,g) LM; (d,h) SEM.

It turns out that the technological porosity depends, among others, on the laser power density resulting from the interaction of the laser power and the diameter of the laser beam, as well as on the flow of protective gas and a dozen or so variables, it can vary from 0.06 to over $10 \%$, which causes almost 2.5 times differentiation in the strength of additive manufacturing materials. Structural studies show that too low laser power density results in the fact that many powder particles do not melt during sintering. Sintering with the liquid phase's participation cannot occur, while diffusion processes do not occur [315-318]. Therefore, the technological process carried out under these conditions is far from correct.

Figure 27 shows a diagram of the SLS selective laser sintering process [137,293,319,320]. It is worth noting that this technology belongs to the group of Powder Bed Fusion (PBF) processes. The literature has different names for additive manufacturing AM's technological processes, which are identical or very similar in principle. Such processes include, among others [293,319]: Selective Laser Melting (SLM), direct metal laser sintering (DMLS), or high-temperature laser sintering (HTLS). As these processes are similar in terms of basic operation principles, it is advisable to use SLS. The study of the differences between these processes practiced, e.g., in dentistry, is unjustified and pointless. The essence of the process is sintering with the participation of the liquid phase sintering LPS. It means that each powder particle is melted or, when it is very fine, even completely melted. Generally, it does not completely melt, remelting the joined material and even any of its successive layers of powder (Figure 27) [137,315]. Liquid phase sintering (LPS) consists of sintering with the coexistence of a liquid and a solid during all the sintering process or its part [321], which then arises, ensures that the undissolved powder particles or their cores contained in 
the mixture are wetted [322,323]. The liquid is subject to capillary forces [324,325], which results in densification, a further fusion of the solid with increased surface energy, and subsequent solidification of the liquid phase [321]. Mass transport speed in the liquid phase is hundreds of times faster than in solid sintering [315]. The improvement of the liquid phase's wettability and the change of the surface energy is favored by increasing the system temperature, thanks to which the sintering intensity increases [326]. This mechanism practically does not occur in pure elements and is appropriate for multi-phase steppes, especially for multi-component powders. The process consists of melting at the boundaries of each powder particle, and the share of solid's diffusion processes is then of marginal importance. Such a liquid phase sintering mechanism is dominant in $90 \%$ of all sintered materials' commercial value $[137,138,292,315]$. The phenomena occurring are similar to those described during the heating of the supersolidus and shown in [137].

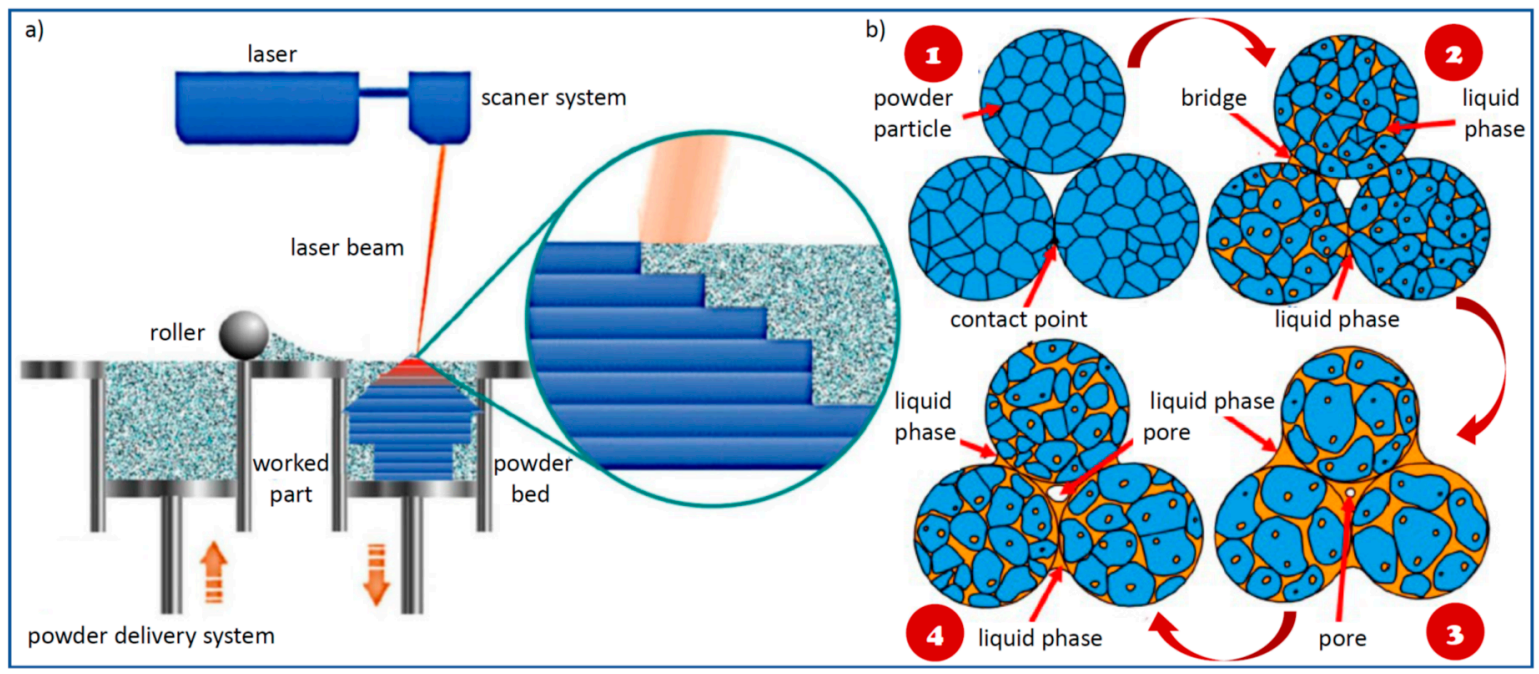

Figure 27. Diagram (a) Selective laser sintering methods; (b) the successive stages of liquid phase sintering.

Unfortunately, this obvious information is unknown in many centers trying to apply additive manufacturing technology in medicine and dentistry. Hence, there will be publications $[327,328]$ in which it is generalized that the properties of additive manufacturing or conventionally cast materials do not differ from each other. It seems to indicate that about $60 \%$ of the possibilities provided by the material used and the additive manufacturing process are used in such a technological process. It is just such a lowering of the manufactured medical and dental devices' properties due to the uncritical application of factory recommendations for additive manufacturing. This type of practice used in medicine and dentistry bears the features of an ethical tort committed both by doctors who apply such manufactured implants or prosthetic restorations and engineers who design and manufacture medical devices with unacceptably low properties exposing patients to significant health damage. It is hard to imagine, but the reason may be even more prosaic, that doctors stock up on an expensive machine and, without an engineering background, do the work on their own. It is an even greater ethical delict that violates the Hippocratic oath principles $[57,58]$. In the name of well-understood patients' expectations, substantive attention should be paid to the irregularities in such papers to avoid false information that cannot be used for patients.

Figure 28 shows a comparison of the properties of metal materials, including titanium, Ti6Al4V alloy, and Co-Cr alloy produced by selective laser sintering and by milling a conventionally cast disc in a CNC milling center, as well as $\mathrm{ZrO}_{2}$ material milled in the pressed state in a CNC milling center from the disc and then sintered. These studies indicate very low strength properties of this sintered material, indicating the maintenance of far-reaching caution in the use of this material in prosthetics and implantology, including dentistry [329]. 


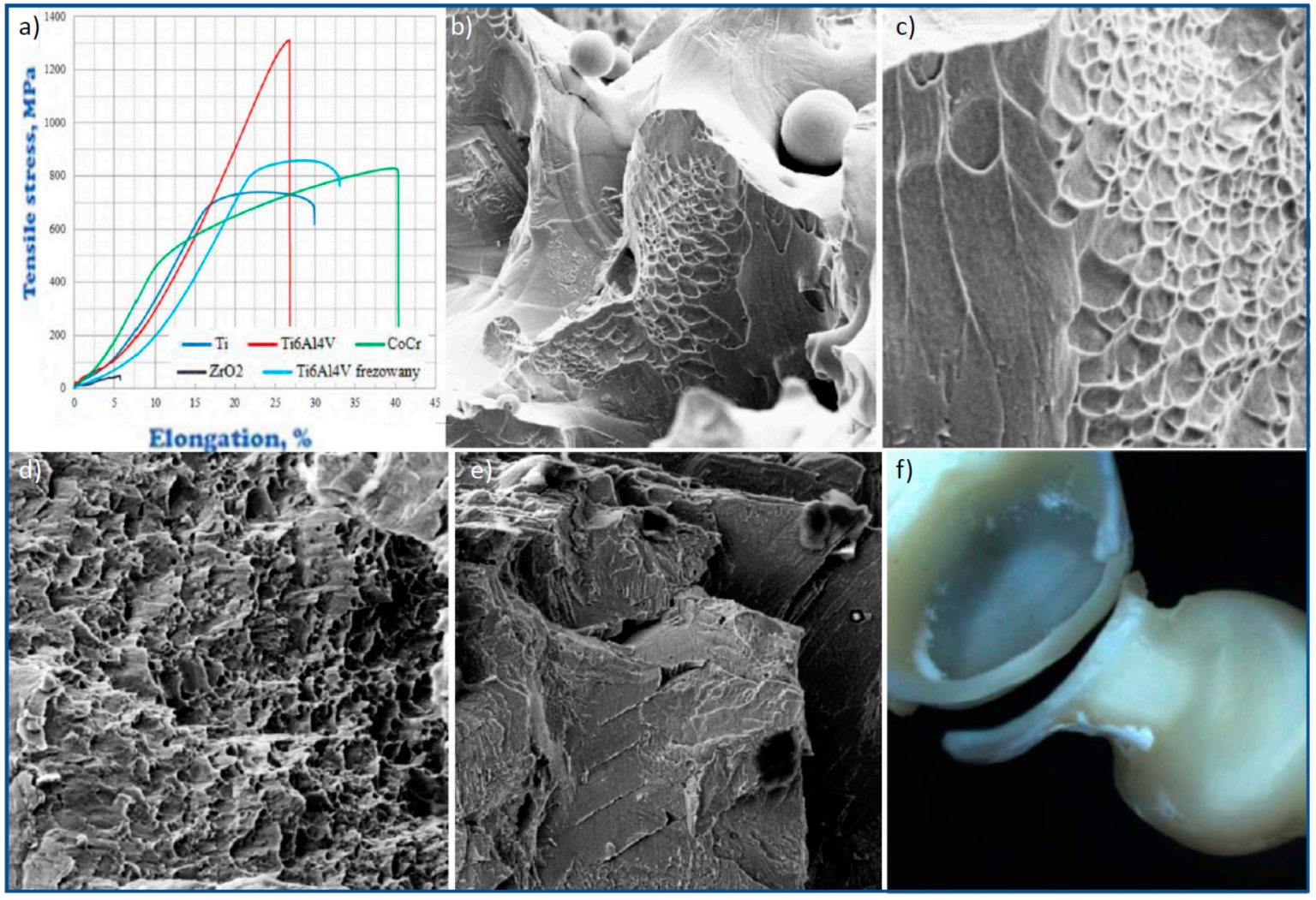

Figure 28. Comparison of the structure and properties of sintered $\mathrm{Ti}$, sintered Ti6Al4V alloy, milled Co-Cr alloy, milled $\mathrm{ZrO}_{2}$ sinter, and milled Ti6Al4V alloy: (a) comparison of the graphs of tensile stress versus elongation; (b-e) fracture structure after static bending test $(\mathbf{b}, \mathbf{c})$ Ti6Al4V solid alloy samples produced by selective laser sintering using a $50 \mu \mathrm{m}$ laser spot after sintering at laser power (b) $70 \mathrm{~W}$; (c) $110 \mathrm{~W} ;(\mathbf{d}, \mathbf{e})$ samples produced by the CAD/CAM method by milling disks from solid alloys: (d) Ti6Al4V, (e) Co-Cr; (f) view of a dental bridge made of $\mathrm{ZrO}_{2}$ sinter produced by the CAD/CAM method by milling the disc and then sintered after a static bending test; (b-e) scanning electron microscope (SEM); (f) stereoscopic microscope.

For this reason, $\mathrm{Co}-\mathrm{Cr}$ alloy is still of great importance in dental prosthetics. Figure 29 shows an example of manufacturing a full-arch prosthetic bridge based on tooth abutments through milling in a CNC center from conventionally cast discs.

Porous materials made from powders by additive methods are very useful in some applications [137,138,282-288,292,293]. Figure 30 shows the results of studies on selectively laser sintered porous titanium [144], including the structure observed in the high-resolution transmission electron microscope HRTEM.

The original concept of porous materials or porous zones on a solid substrate was used, among others, in metal implant-scaffolds produced by selective laser sintering [330-334]. Implementing this concept, both in dentistry and orthopedics, is possible to design and manufacture a solid core and a porous surface layer. Living cells, most often osteoblasts, can grow. Surface layers also play an important role, making engineering materials useful in these applications, which meet the stringent requirements to a lesser extent. Figure 31 shows the research results on the application of 1000-1500 layers of $\mathrm{Al}_{2} \mathrm{O}_{3}$ and $\mathrm{TiO}_{2}$ using the atomic layers deposition method with a total thickness of $1-3 \mu \mathrm{m}$. It is the only method that allows the coatings to be applied inside the porous structure without producing a shadow effect. HRTEM studies show that the nanostructured layer is situated on the crystalline substrate without any discontinuities and gaps. 


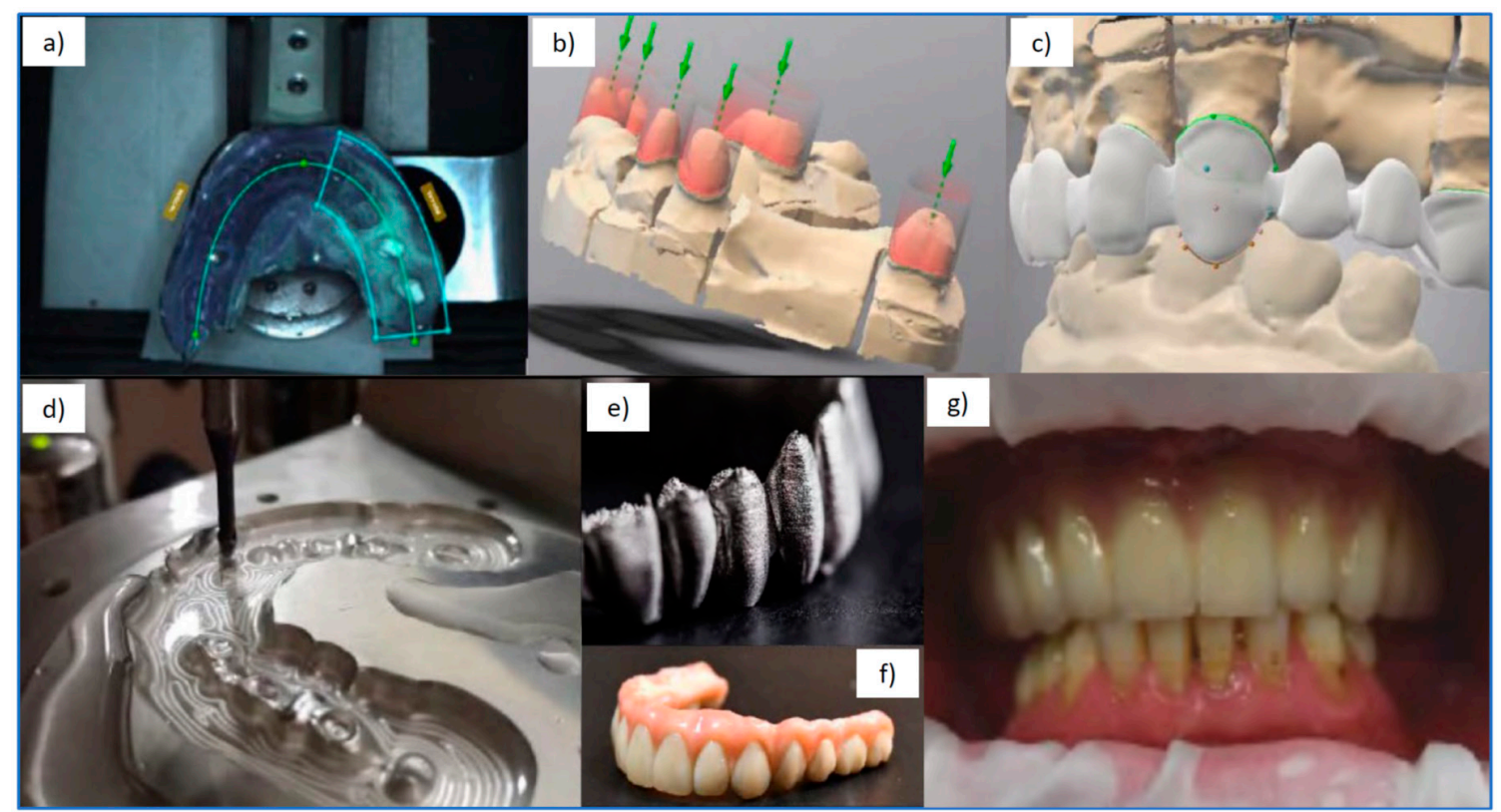

Figure 29. The procedure for manufacturing dental bridges using solid metal block milling technology; (a) a dental impression which is then scanned directly from the impression spoon; (b) the verification of the parallelism of the pillars; (c) the finished foundation design for transferring from CAD to CAM; (d) using the CNC milling center, the foundation is produced; (e) the finished element after cutting; (f) the prosthetic restoration veneered with porcelain; (g) the bridge installed in the patient mouth.
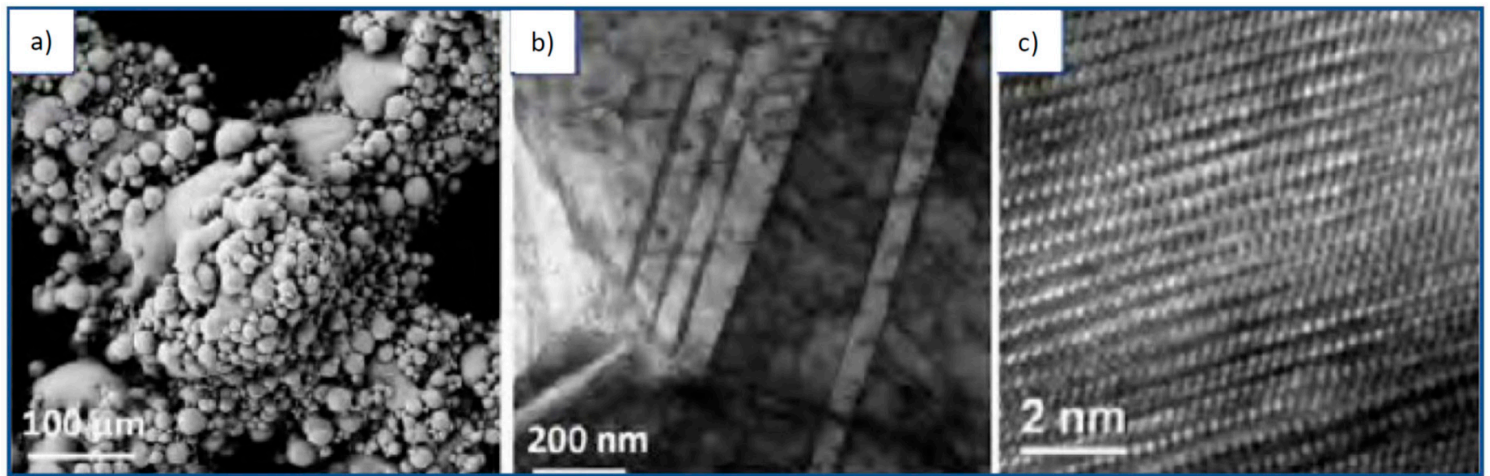

Figure 30. Structure of selectively laser-sintered titanium; (a) skeleton topography with a pore diameter of $\sim 450 \mu \mathrm{m}$ (SEM); (b) Ti- $\alpha$ martensite crystal structure in the thin foil (TEM); (c) distribution of Ti atoms in Ti- $\alpha$ martensite (HRTEM).
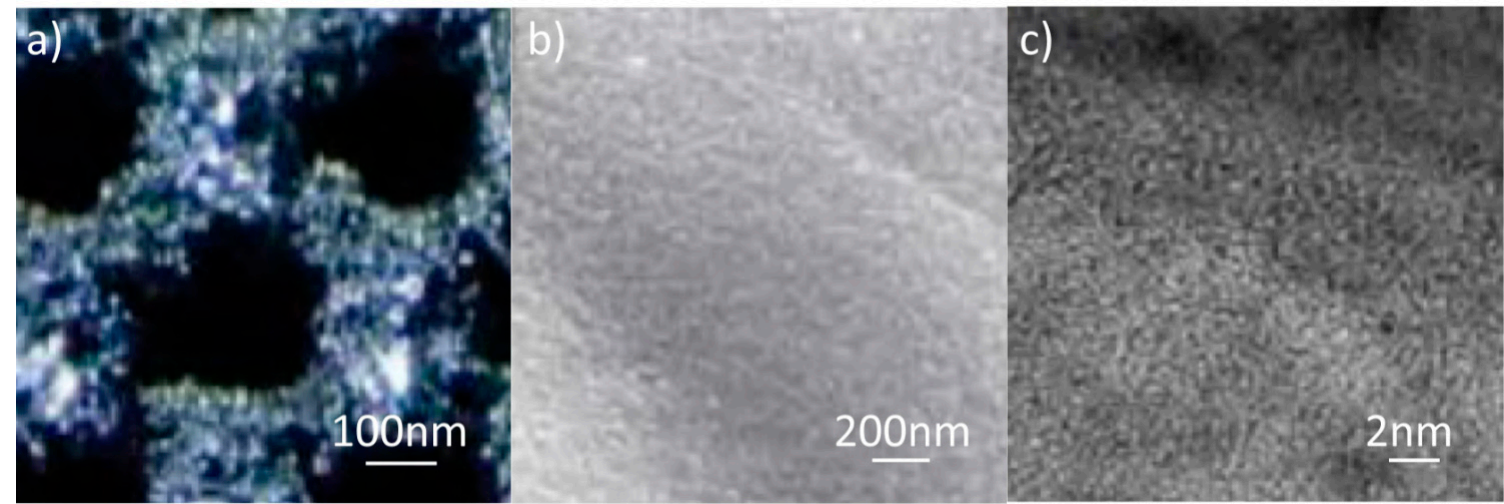

Figure 31. The surface structure of SLS titanium coated with $\mathrm{TiO}_{2}$ coating during 1500 cycles; (a) Surface topography (stereoscopic microscope); (b) surface image (SEM); (c) amorphous $\mathrm{TiO}_{2}$ coating layer (bottom) and titanium crystal structure (top) (HRTEM). 
In this context, biological research plays an important role. Many original studies have been carried out $[289,290]$, which indicate alloys' favorable behavior with a titanium and cobalt matrix. It concerns biocompatibility, toxicity, corrosion resistance, and tribology. It is very advantageous to use surface layers that favor the growth of living cells, as shown in Figure 32.

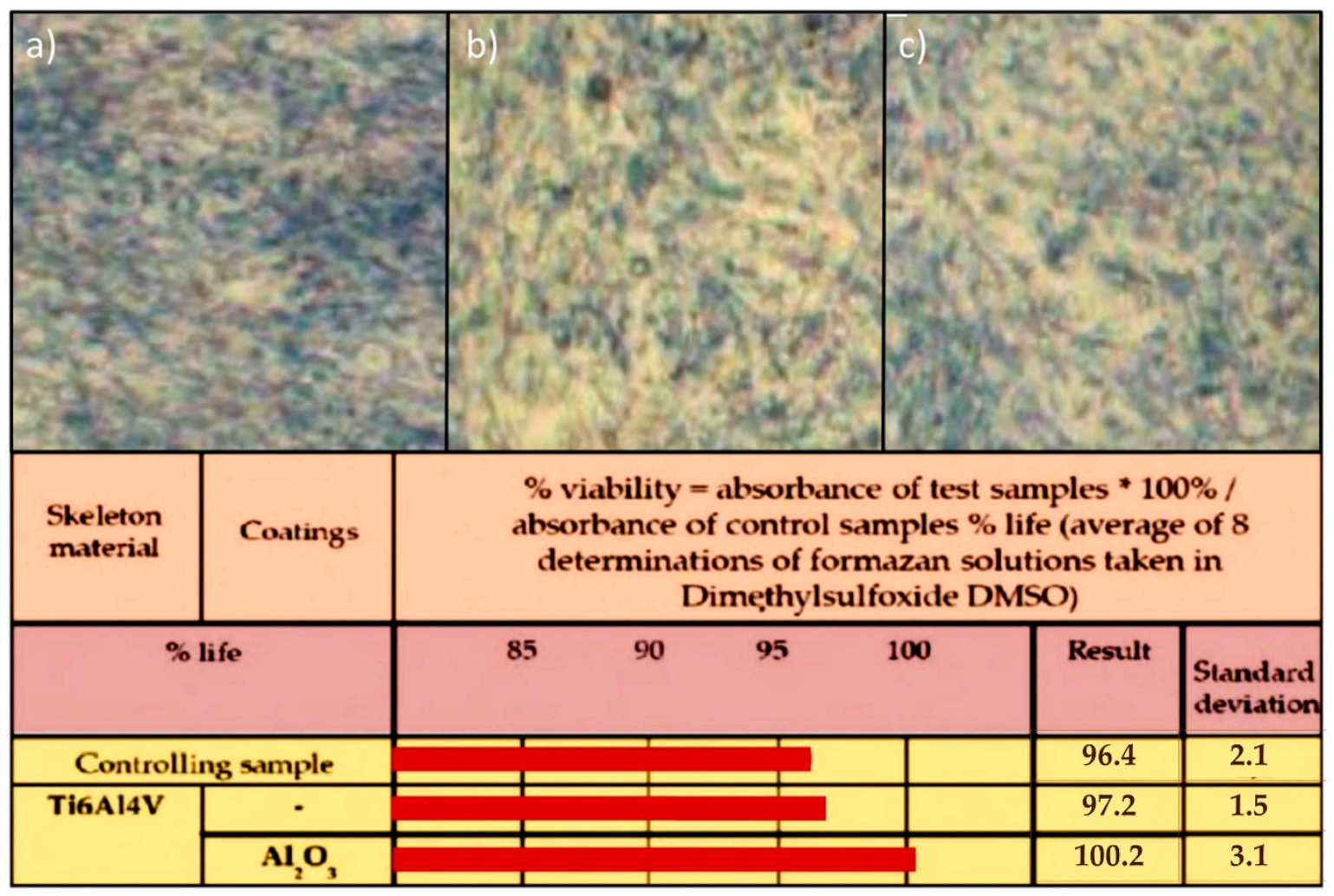

Figure 32. Images of specimen surfaces (light microscope, fluorescent contrast); (a) control glassware; (b) $\mathrm{Ti}_{6} \mathrm{Al}_{4} \mathrm{~V}$ alloy without surface layer; (c) $\mathrm{Ti}_{6} \mathrm{Al}_{4} \mathrm{~V}$ alloy with $\mathrm{Al}_{2} \mathrm{O}_{3}$ coating applied by the ALD method.

Nanostructured materials are increasingly used, or this group of materials is used in biomedical materials and devices, e.g., as reinforcement of biomedical composite materials or as elements of layers used in medical devices, shown in Figure 31. Sometimes this group also includes inorganic substances and natural macromolecules (biopolymers), useful for various medical devices, including prostheses, even if they do not meet the general definition of engineering materials. It should be noted that the materials of this group can often be used in veterinary medicine and animal husbandry. The requirements in such cases are similar to those for medicine and dentistry, although the legal provisions regulating these different application aspects are usually completely other. The most common types of biomedical materials were engineering materials used in varieties requiring exceptional purity due to their medicine or dentistry applications. Currently, many materials are specially developed to a much greater extent, e.g., polymers, biopolymers, and various inorganic substances dedicated exclusively to medical applications and not applicable in other areas of materials science. Examples of the use of gutta-percha in dental endodontic treatment are presented (Figure 33) [16,335,336]. 

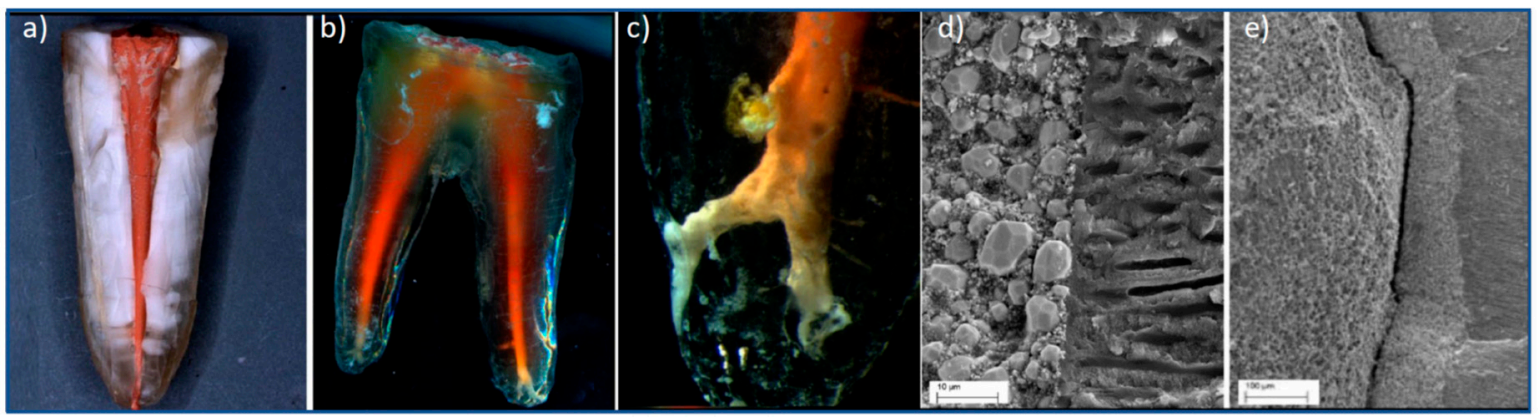

Figure 33. Examples of endodontically treated tooth with root canal filled with gutta-percha material with AH Plus sealant by the thermoplastic method: (a) longitudinal fracture of the tooth; $(\mathbf{b}, \mathbf{c})$ decalcified teeth; (c) root delta of the transverse fracture of the canal dentin; (d) in all sections of the root canal the material based on gutta-percha and sealant is tightly connected; (e) the border of three layers: a sealant layer covering the material on the gutta-percha matrix in a leak between a thick intermediate layer of sealant and the sealant with tightly connected dentine of the root canal after an incorrectly performed procedure; (c) atomic force microscope; (d,e)—scanning electron microscope.

Another example of polymeric materials is the design and manufacture of surgical guides used in dentistry, shown in Figure 34 [337,338]. The template is made of lightcured polymeric materials using the SLA stereolithography technology. According to the own invention, a special type is a template containing the accessory enabling implants' insertion [339].
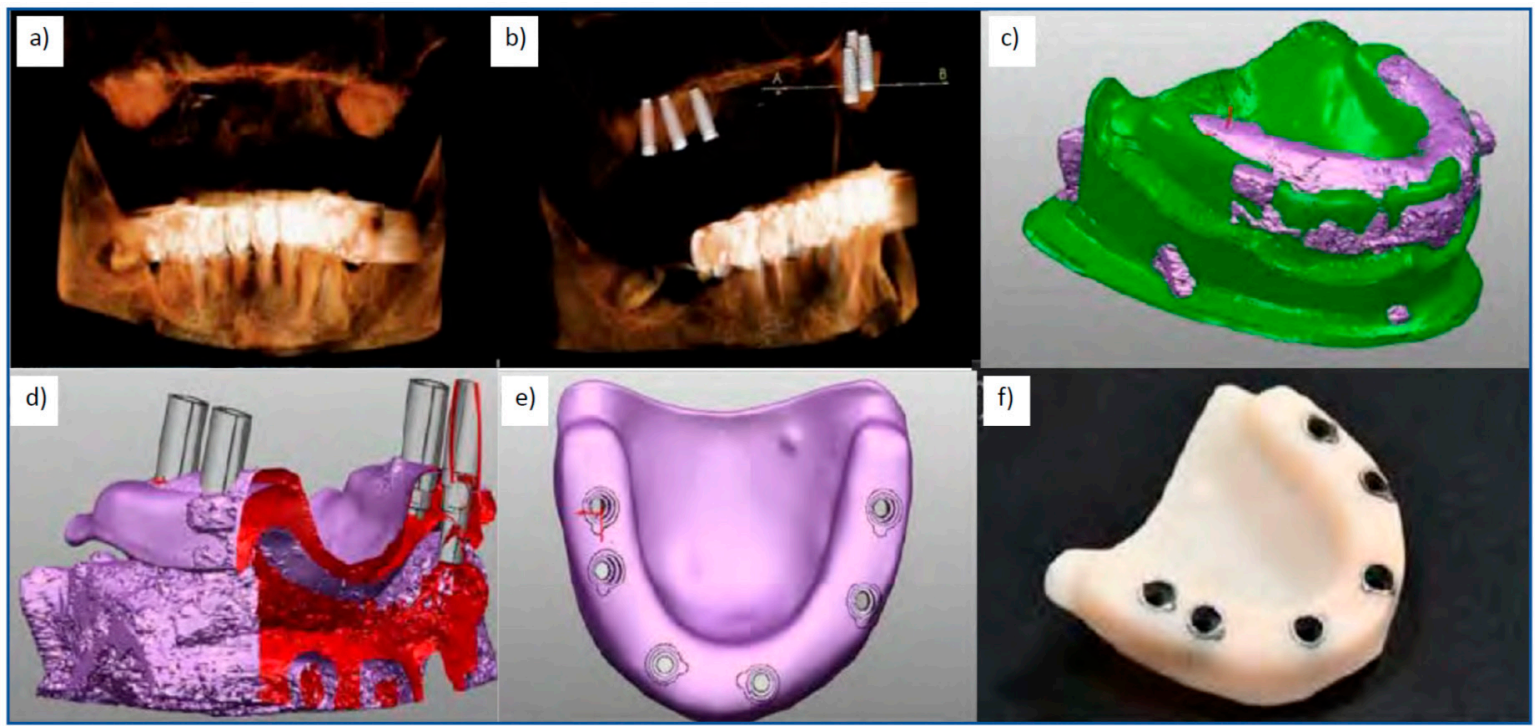

Figure 34. The procedure for making the template for implantation of six implants; (a) a 3-D model created based on CBCT; (b) planed the placement of implants; (c) the ready bone base model folded together with the intraoral model using an individual positioning plate; (d,e) two views of a model of the drill guide tubes; $(\mathbf{f})$ the ready template plate using the 3-DP SLA technology.

Another example of polymeric materials is nanofibers obtained by electrospinning, especially long-absorbable composite nanofibers with a bioactive core and a bactericidal coating. Polymer nanofibers can find application in medicine provided that their potential toxicity is eliminated, starting with the materials used for obtaining solutions and taking into account a set of other factors [154]. In coaxial electrospinning (Figure 35a), moderately volatile solvents, such as a mixture of formic acid and hydrochloric acid of the rotary collector, are used to prevent the tendency of nanofibers to stick together. Composite nanofibers of the core-shell type (Figure 35b), combining the antibacterial properties of the coating with the core's bioactive properties, are an attractive material for a threedimensional tissue scaffold, porous implant-scaffolds, for an innovative generation of 
flexible composite materials for regenerative medicine. When silver nanoparticles are deposited on nanofibers' surface (Figure 35c), high bactericidal properties can be ensured. Silver nitrate and AlphaSan are highly effective in combating Gram +, Gram- bacteria, and fungi, and the high-molecular chitosan has no antibacterial and antifungal properties. Such materials can also serve as a carrier for drugs and, in the form of soft mats, as dressings, e.g., in the event of burns, or as cells' carriers attached to the burned skin.
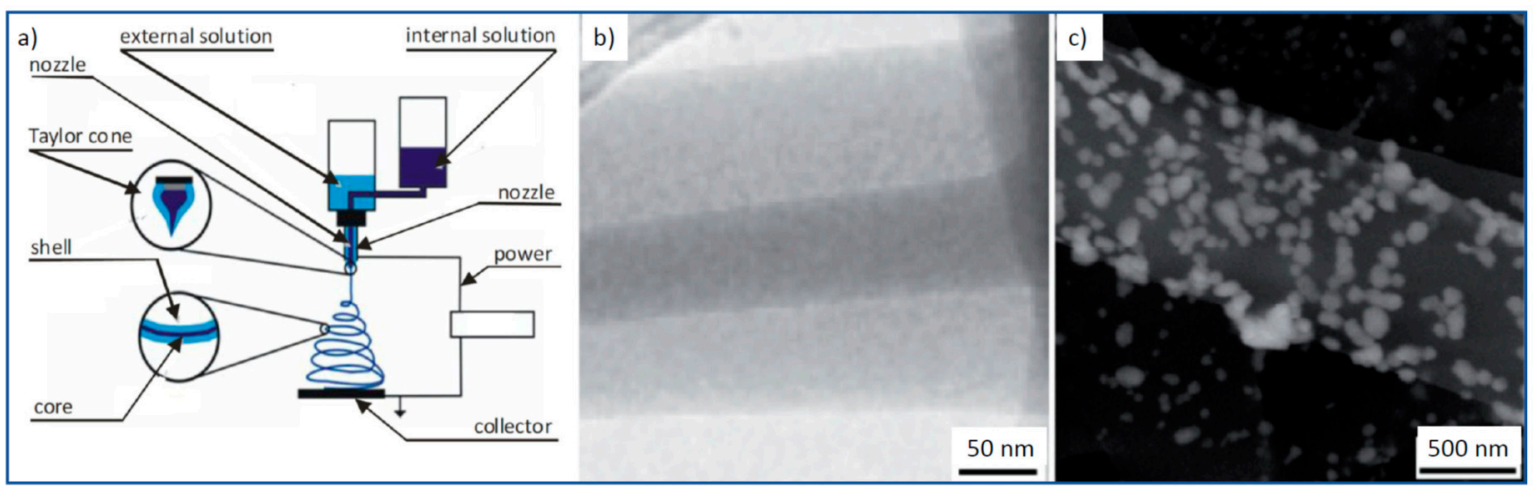

Figure 35. Manufacturing of polymer nanofibers by electrospinning for application in regenerative medicine: (a) scheme of the manufacturing method; $(\mathbf{b}, \mathbf{c})$ geometrical characteristics of the core-shell composite obtained from (b) a coating solution of $10 \%$ polycaprolactone without additives and inner core solution of $4 \%$ of polycaprolactone without additives (TEM), (c) double-component fibers obtained by dissolving PCL granulate with the molecular mass of Mw $=70,000-90,000 \mathrm{~g} / \mathrm{mol}$ using $10 \%$ mixture of hydrochloric acid and formic acid with a mass ratio of 70:30 with the addition of $25 \%$ of $\mathrm{AgNO}_{3}$; the photograph was taken after precipitation of silver in $2 \%$ ascorbic acid solution (SEM).

In 1992, the development of regenerative medicine began, closely related to the subject of biomaterials and implantology, especially with the use of bionic medical implants [340]. Bionics is concerned with designing, manufacturing, and studying artificial engineering systems that can restore lost functions of biological systems [341,342]. The replacement of organs and tissues occurs by their replacement by autographs, allografts, or devices made of various biomaterials [270]. Methods of treating patients or regenerating the body through cell-based therapies involving the replacement of diseased and old cells and tissues with young cells and gene therapy and tissue engineering methods are regenerative medicine goals. It makes it possible to counteract the causes, symptoms, and sequelae of various diseases [343-346]. Development of biological materials for the reconstruction and improvement of the functions of tissues and/or organs and their substitution with the interdisciplinary use of the principles of natural sciences and engineering, mainly materials, has been the essence of tissue engineering since 1985, constituting a field of technical sciences supporting regenerative medicine [347-352]. The history of the use of live cell therapy in medicine dates back to the first successful allogeneic human hematopoietic stem cell (HSC) transplantation in 1968 [353], and subsequent studies intensified in the last quarter of a century [354-357] relating to, among other things, for cartilage and skin diseases. Adult and embryonic multipotent and self-renewing stem cells (MSCs) $[355,358,359]$ found in umbilical cord blood [360,361], placenta [258], amniotic fluid [362], or the pulp of infant milk teeth are used. Most preferably, to a limited extent, to use autologous cells $[355,363]$ not requiring immunosuppressive treatment [362,364-366].

Somatic, and especially hematopoietic stem cells (HSCs) and bone marrow stromal cells (BMSCs) [355,367-369], and adult stem cells from synovial fluid, tendons, skeletal muscles $[369,370]$ and adult muscles, adipose tissue ASC can be used more commonly (fat stem cells) [369,370], corneal stroma [361], peripheral blood, nerve tissue, and dermis can transform into different tissue types. A prerequisite for cell implantation is preventing ischemia and necrosis [371-376] from maintaining viability [377,378].

In addition to the so-called pure cell therapies consisting of direct injection of stem cells into the peripheral circulation or specific tissues, stem cell carriers are often used 
for their transport, and scaffolds are most often used to group them in selected places in the body [152,154,156,379-388]. A microscopic, porous structure of the scaffolds must ensure diffusion of nutrients and metabolic products, enabling the formation of a threedimensional tissue structure simulating natural solutions $[387,389]$ and ensuring proper vascularization [390-393]. It is needed to develop the technology of producing materials with the required pore structure and select engineering materials that provide the required properties and biocompatibility.

This part of the paper indicates, through numerous examples from the authors' own clinical and manufacturing practice, how important the success of countless clinical procedures is the correct design of the concept of the medical devices, the biomaterials used for their production manufacturing processes. Increasingly better quality of biomaterials and engineering materials used in the production of numerous medical devices, ranging from implants, through surgical tools, to hospital beds and rehabilitation equipment, is an extremely important factor. Any research to improve the properties of biomaterials and products derived from them serving improve patients' health, relieve pain during illness, and often allowing them to return to everyday life and ensure normal living and working conditions are highly desirable. The engineering activities in bioengineering have a fundamental impact on the level and quality of manufactured medical devices and the fulfillment of the described expectations and requirements set by the Industry 4.0 stage. Technological processes of manufacturing and processing biomaterials are extremely important, including additive processes, electrospinning, and sophisticated surface engineering methods, e.g., atomic layers deposition.

These aspects have an immediate effect on the expected high standard of living, good health, and well-being when they require improvement through medical intervention. For this reason, a lot of attention has been paid to these aspects in this part of the paper.

\section{Economic Conditions for the Implementation of Various Groups of Biomedical Materials}

The above-mentioned technical achievements and the systematic increase of the application areas are accompanied by the dynamic growth of the biomaterials market and its value. The development trend of the biomaterials market has continued over the last two decades and is expected to continue in the 2020s. The market is divided into five main categories, depending on the type of products, technology of manufacture, and type of medical condition, with regard to the eyes, ears, orthopedics, heart, and nervous system, and brain. The market for dental implants and dentures is separate. Safe, reliable, and inexpensive biomaterials include metals, ceramics, polymers, and naturally derived biomaterials. So far, metal materials have had the largest share in the global biomaterials market, with the rapidly growing share of polymeric biomaterials. It should be noted that among the metal materials used as biomaterials, the use of austenitic steels resistant to corrosion, popular in the previous decades of the 20th century, has virtually been eliminated due to the identified allergic effect of nickel present in these steels and the restrictive directives introduced by the European Union in this regard. Instead, their use of titanium and magnesium and their alloys have increased significantly.

The value of the global biomaterials market in 2019 was estimated at USD 106.5 billion in 2019, and it was estimated that in 2020-2027 compound annual growth rate, CAGR, will amount to $15.97 \%$ (Table 3). The undoubted cause of such dynamic growth is, among others, the increasing frequency of diseases of the musculoskeletal system and chronic diseases of the skeletal system, as well as the very widespread prevalence of diseases of the oral cavity. The structure of biomaterial applications is illustrated in Figure 36a. Figure 37 shows the dynamics of growth in this market's value in the United Kingdom. It should be noted that the markets related to biomaterials and other avant-garde material technologies discussed here only partially overlap. Therefore, apart from analyzing the overall market, it is worth paying attention to a few detailed ones. 
Table 3. The current value of various global biomaterial markets and the related forecast compound annual growth rates CAGR.

\begin{tabular}{|c|c|c|c|c|c|c|}
\hline Attribute & & & & & & \\
\hline Type of Global Market & Biomaterials & $\begin{array}{c}\text { Dental } \\
\text { Biomaterials }\end{array}$ & $\begin{array}{c}\text { Orthopedic } \\
\text { Biomaterials }\end{array}$ & $\begin{array}{c}\text { Tissue } \\
\text { Engineering }\end{array}$ & $\begin{array}{l}\text { Regenerative } \\
\text { Medicine }\end{array}$ & Cell Therapy \\
\hline Unit & USD billion & USD million & USD billion & USD billion & USD million & USD billion \\
\hline Base year for estimation & 2020 & 2020 & 2018 & 2019 & 2016 & 2020 \\
\hline $\begin{array}{l}\text { Market size value in } \\
\text { based year }\end{array}$ & 121.1 & 7.983 & 11.96 & 9.9 & 5444 & 6.09 \\
\hline Forecast period & $2020-2027$ & $2019-2025$ & $2019-2025$ & $2020-2027$ & $2017-2023$ & $2020-2027$ \\
\hline Growth Rate CAGR, \% & 15.97 & 7.41 & 10.3 & 14.2 & 32.2 & 5.4 \\
\hline Literature & [394] & [395] & [396] & [397] & [398] & [399] \\
\hline
\end{tabular}

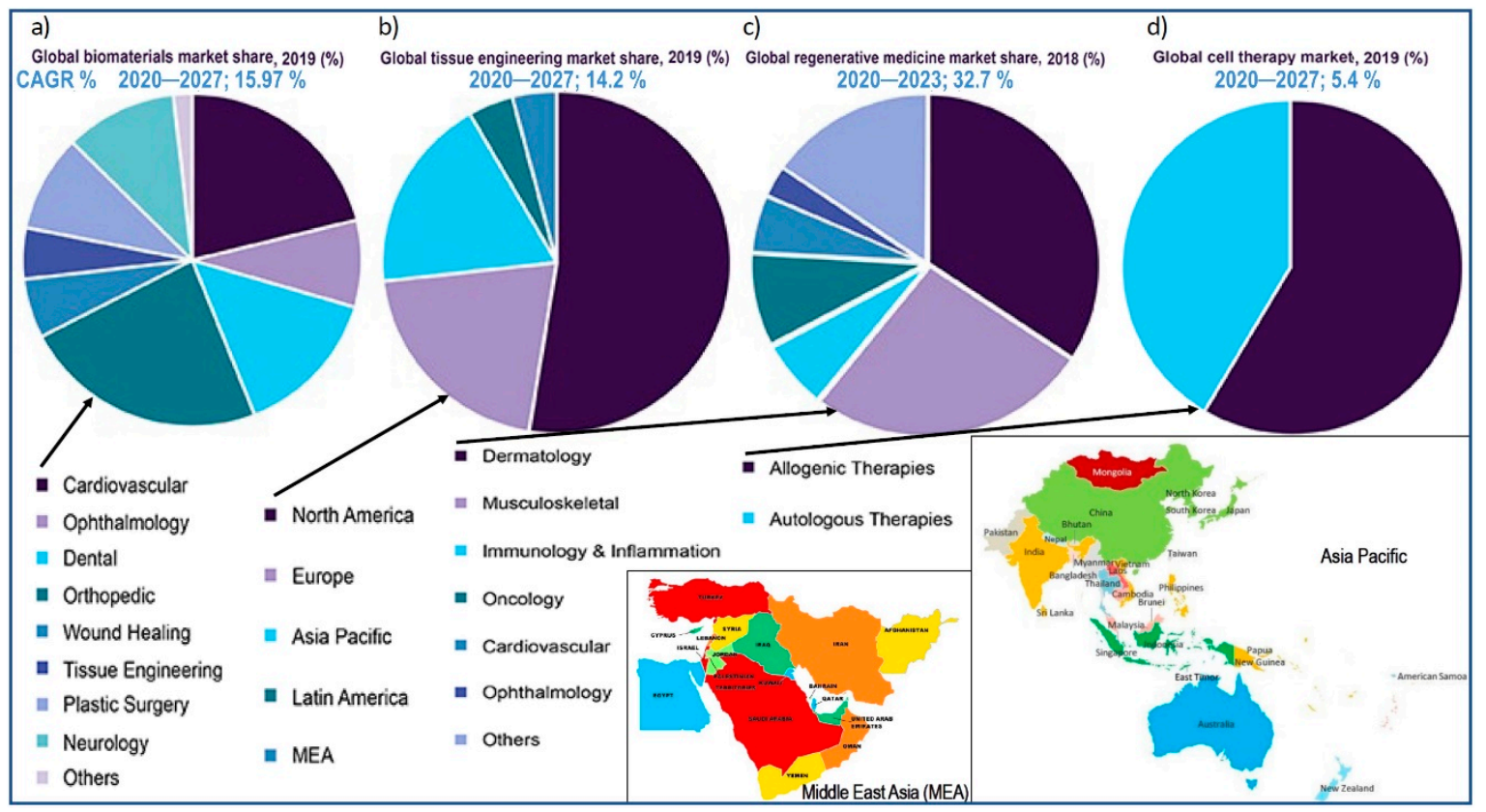

Figure 36. The structure of global markets due to (a) the use of biomaterials for the treatment of various diseases; (b) involvement of individual geographic regions in tissue engineering technologies; (c) the suitability of regenerative medicine methods for treating multiple diseases; (d) the contribution of allogeneic and autologous cell-mediated therapies.

The increasing scale of oral diseases leads to toothlessness and, consequently, to advanced implantology and dental prosthetics, which results in the forecast of an increase in the value of the dental biomaterials market from USD 7983 billion in 2020 in the period 2019-2025 with a CAGR of 7.41\%. The popularity of dental biomaterials is due to the increasingly common problems with oral health and the population's progressive aging. It is not without significance that dental care has been privatized quite commonly and in many countries. Therefore the range of expectations of many people in dental care is increasing due to the growing wealth of many people. The dental biomaterials market is divided into metal, ceramic, polymers, and natural materials. The latter segment is to record the value of the incremental value in the string of means of payment. They will impact nanotechnology's latest achievements, leading, among other things, to the work of dental autogenous bone grafts. 


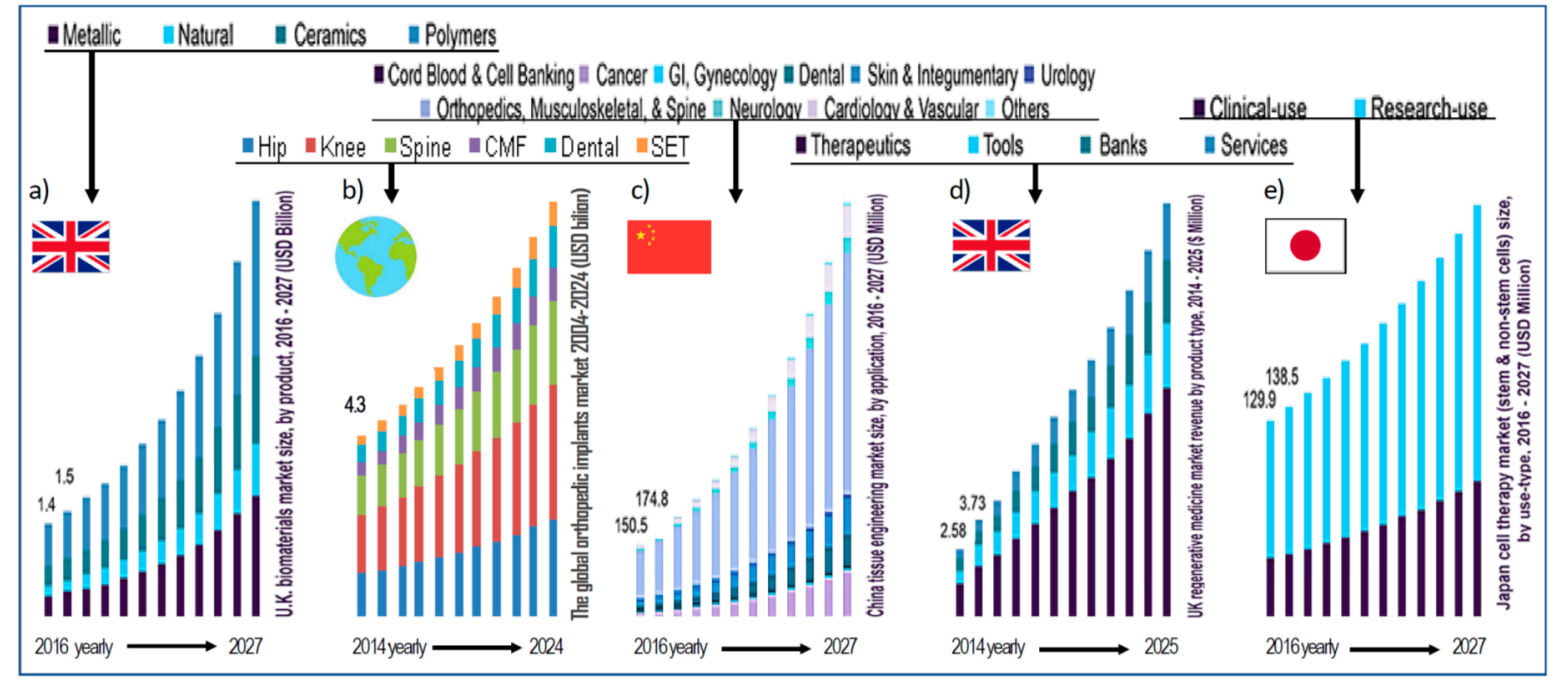

Figure 37. Forecasts of market growth until 2024-2027, respectively: (a) types of biomaterials in the UK; (b) the purpose of the main groups of orthopedic implants in the world; (c) the allocation of various tissue engineering methods in China; (d) different application groups of biomaterials in regenerative medicine in the UK; (e) the scope of the therapy goal in Japan.

The increased risk of osteoarthritis, osteoporosis, and other musculoskeletal disorders that come with adulthood, the social scale of which is increasingly widespread due to the growing geriatric population globally, is why the demand for orthopedic implants. It is directly related to the increase in the orthopedic biomaterials market's value from USD 11.96 billion with a CAGR of $10.3 \%$ (Table 3). The dynamics of the increase in the value of this market are shown in Figure 37b.

The main market for orthopedic joint replacement implants is those used in knee and hip replacement surgery (Figure 38), mainly aimed at alleviating patients' pain and restoring limb function. This global market reached over USD 16.5 billion in 2017, and its CAGR has increased by more than 3\% since 2013 [400] and is broken down by common type for knee or hip replacement implantation. In the case of the knee replacement implant, the CAGR was relatively higher, and in the historical period, it reached a CAGR of nearly $4 \%$. The largest market for major orthopedic joint replacement implants in North America with $54 \%$ of the world market, followed by Western Europe and the Asia-Pacific region, with this region and South America expected to develop the fastest. It increase was justified by the increase in the number of older people, the increase in the prevalence of obesity and arthritis, and the increasing level of knowledge about the positive importance of joint replacement surgery, taking into account the high cost of surgery and the relatively high share of failure, as well as the significant development of novel conservative therapies for arthritis.

However, significant advances in surgical techniques have been noted, e.g., the implementation in 2015 of a robotic total hip arthroplasty system [401-419], which improves the procedure's accuracy and precision to four times greater than in the case of manual implant placement. Increasingly, to increase the speed and efficiency of joint operations, additive methods, the so-called 3D printing, manufacturing of implants [420-423] after initial replication of components used in the process using patient's X-rays or computed tomography. Implants can be manufactured from solid and porous pieces fabricated in the same element or product to provide patients with individual knee or hip replacement. Metals and ceramics are the largest segment of orthopedic implants in the hips and knees, respectively, although polymeric materials also play a role. The most common, however, is a combination of cooperating elements in both types of these implants. By type of material combination-the hip replacement implant market is broken down by material combination type into [400]: Metal on Polymer (MOP), Ceramic on Polymer (COP), Ceramic on Ceramic (COC), Metal on Metal (MOM) and Ceramic on Metal (COM), although for the 
knee replacement implants these combinations are limited to MOP and COP only. The MOP market is the largest for both ponds. There are three possibilities of fixing both implants' types without cement, either cemented or hybrid with partial cementation. Cementless fixation is more commonly used for hip implants, while for the knee joint, it is more widely used for cement fixation.

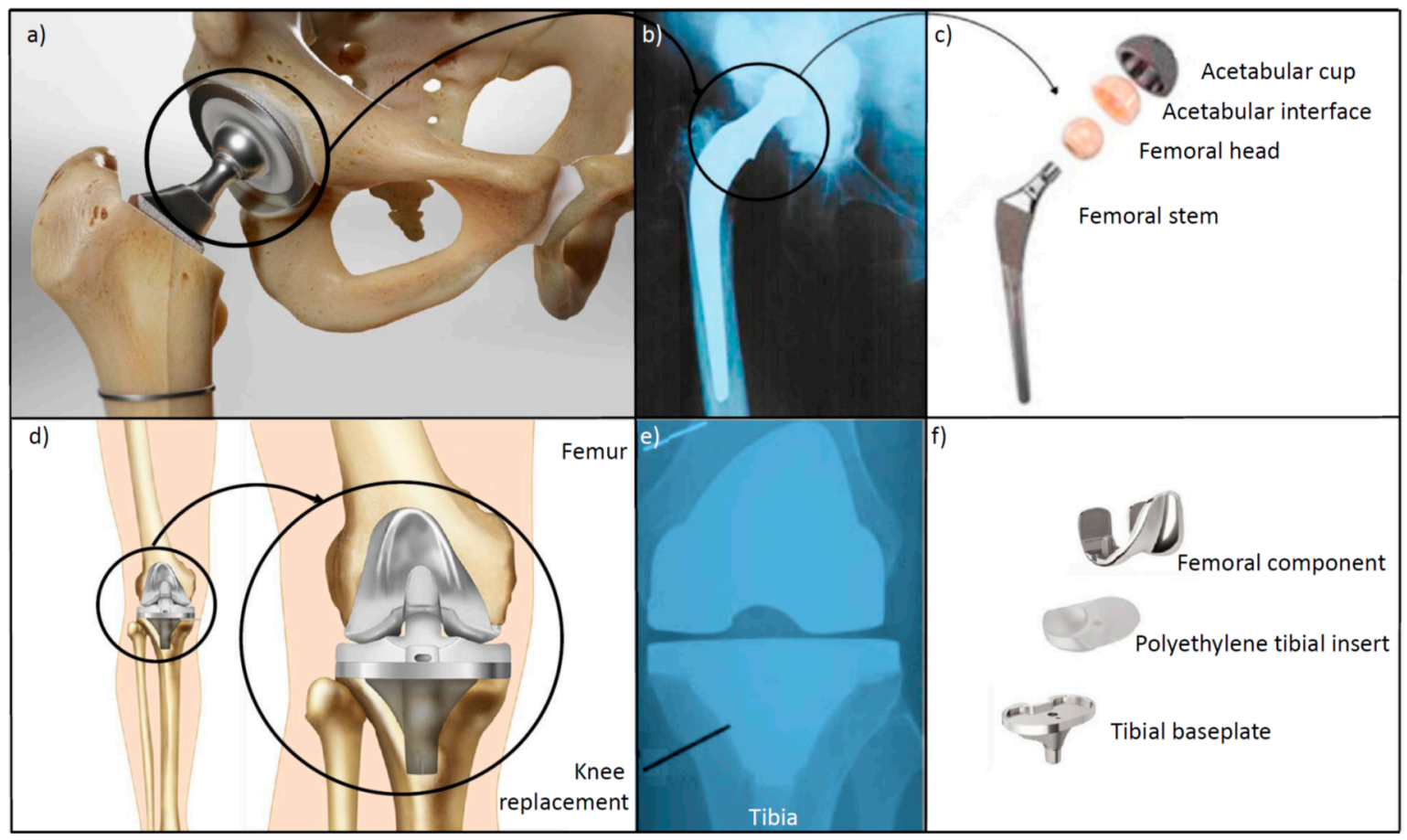

Figure 38. Scheme of application of orthopedic implants $(\mathbf{a}-\mathbf{c})$ of the hip joint; $(\mathbf{d}-\mathbf{f})$ knee joint; $(\mathbf{a}, \mathbf{d})$ general view of the application method; (b,e) X-ray pictures after installing the implant in the human body; (c,f) assembly diagram for implants' construction.

For hip replacement, the global market size was estimated at USD 7.13 billion in 2018, forecasting to grow to USD 10.51 billion in 2026 with a CAGR of 5.0\% during the forecast period [424]. It must be stated that the information provided in other reports is less optimistic [424-427]. This market is divided into total hip implants, which had the largest market share since 2018, and the revision hip. The growing demand for minimally invasive surgeries and continuous technological advances favor the ever-increasing importance of other types of partial femoral head replacement and hip resurfacing. Hip arthroplasty surgery is an alternative to total hip replacement, allowing for alignment rather than a complete replacement, increasing the market share of hip replacement implants. New technologies and navigation systems are constantly being implemented to facilitate and simplify surgical procedures. For example, in 2018,3D total hip arthroplasty was performed for the first time [428], and in 2019, an intelligent navigation application for hip surgery was implemented $[429,430]$. In the hip joint replacement market, the share of MOP implants is the largest because it is the most cost-effective, causes fewer complications than other types of materials, and shows better tribological properties. MOM, on the other hand, is widely used for total hip replacement and revision hip replacement surgery. However, too frequent postoperative complications may cause a decline in interest in this type of implant in the near term, unlike the COP market, which is expected to grow dynamically due to the low complication rate postoperative and the lowest wear rate.

The global knee replacement implant market is projected to grow at a rate of $5.3 \%$, from USD 10.01 billion in 2019 to USD 15.33 billion in 2027 [431]. However, information on this in other reports is ambiguous [431-434] and generally less optimistic. Knee arthroplasty, also known as knee arthroplasty, alleviates pain and disability in patients with knee deformities 
in the face of an increase in the geriatric population, combined with an increase in obesity and osteoporosis. Total knee prostheses had the highest share of around 75\% in 2019, but the percentage of partial knee replacement increases with a CAGR of $6.7 \%$ as only the damaged part of the knee is replaced. A knee revision means the amount needs to be replaced. The artificial material used in arthroplasty as a knee joint implant restores the function of the knee. The United States is the largest market for these products due to the use of technologies such as 3D printing, and the CAGR of this market is $5.0 \%$ in the US. Total knee arthroplasty is performed in $75 \%$ of cases. In Germany, the CAGR is $4.1 \%$. Among the causes of these operations, the main reasons are osteoarthritis and ligament rupture, road and sports accidents, and related injuries. Usually, the recovery period after surgery takes six weeks. Still, efforts are being made to shorten the healing period by introducing innovative devices and technologies, including the so-called 3D printing increase in osteoarthritis incidence among adults. The high cost of implants reduces the pace of market growth, which are favored by the popularization of minimally invasive operations, the implementation of advanced technologies, and the improvement of the materials' strength properties from which the implants are made. Due to nickel toxicity, stainless steel with an austenitic structure has completely lost its importance, while the most commonly used metals for knee prostheses are Co-Cr alloys. Pure titanium is biocompatible, as is its Ti6AI4V alloy, and is, therefore, the most desirable material in this application.

Tissue engineering is an alternative to mechanical devices used to treat damaged tissues, surgical reconstruction, and transplants. Cell therapies, mainly with stem cells, are gaining more and more therapeutic importance in various clinical areas and the management of numerous diseases, including cancer, diabetes, obesity, and other chronic diseases caused by an aging population, lifestyle changes, and the growing number of, among other things, as a result of traffic and sports accidents. With the use of stem cells, it is possible to functionally revitalize an organ or its substitution by transplanting an artificial organ with the help of cultured stem cells, such as in a pacemaker produced in this way. Technological progress in this area is also associated with the automation of archiving and processing stem cells, which is undoubtedly one of the key factors of tissue engineering progress. The value of the global tissue engineering market in 2019 was USD 9.9 billion. It was also estimated that in the years 2020-2027, the CAGR will amount to $14.2 \%$ (Table 3). Figure 36a shows the geographical distribution of tissue engineering in important economic areas in the world. Figure 37c gives an example of a very high estimated increase in tissue engineering in China.

It has been estimated that the global regenerative medicine market is developing the most intensively in terms of value in 2017-2023, which in 2016 reached USD 5.44 billion, and the CAGR in 2017-2023 was estimated at an extremely high level of 32.2\% (Table 3). Figure $36 \mathrm{c}$ shows the role of regenerative medicine methods in the treatment of various diseases. The increase in regenerative medicine in the United Kingdom is given as an example (Figure 37d). In the regenerative medicine market, key players focused on new products to treat cardiovascular diseases, diabetes, cancer, neurological disorders, and regenerative drugs. Figure 39 shows the share of various materials, including synthetic, genetically engineered, and pharmaceuticals and dynamic forecasted growth, and the increased importance of biologically derived materials in 2016-2023, a strong development determinant of regenerative medicine in general. 


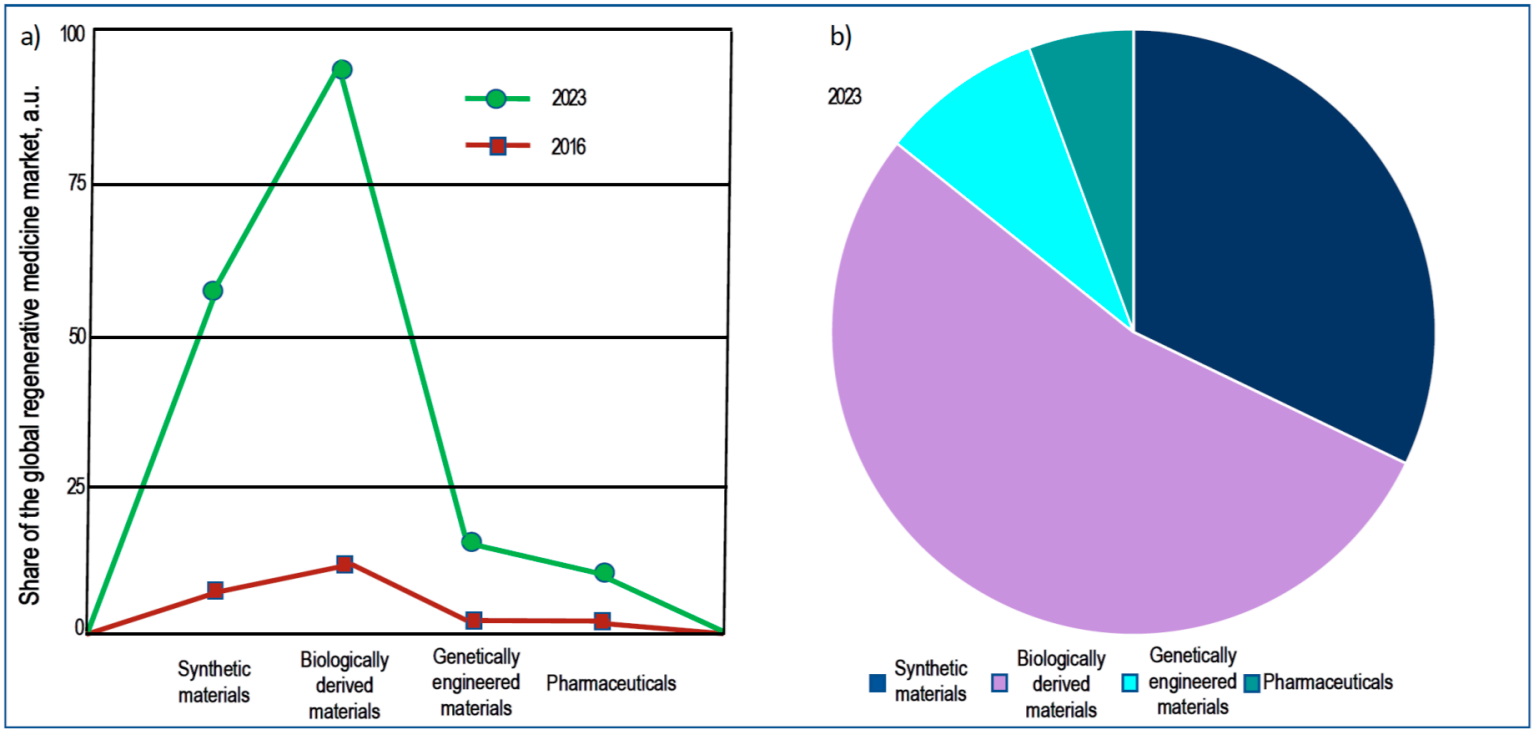

Figure 39. Scheme of forecasting the increase in the share of various groups of biomaterials used in regenerative medicine in the world in 2016-2023: (a) bar chart; (b) pie chart.

Advances in stem cell therapies such as the treatment of leukemia and blood diseases with hematogenic stem cells support regenerative medicine. The value of the cell therapy market in 2020 was USD 6.09 billion, and a CAGR of 5.4\% is forecasted for 2020-2027 (Table 3). Figure 37e shows an example of the cell therapy market's growth in Japan, while Figure 36d shows cell therapies' division into predominantly, slightly allogeneic, and autologous.

In light of changes in the world caused by the SARS-CoV-2 coronavirus pandemic, adjustments to the forecasts described above can be expected, which will not change the global markets' general development trend. However, the high CAGR forecasts will decrease. Relevant reports in this regard will most likely be published, although the scale of the correction will be indicated by life and the passage of time.

This chapter analyzes in detail the expected growth of the biomaterials, both orthopedic and dental markets in the coming years, and the expected growth of tissue engineering, regenerative medicine, and related cell therapies markets. The compound annual growth rate CAGR of each of these markets is diversified, as the lowest CAGR is approx. $5.5 \%$, and the highest CAGR is approx. $32 \%$. Most of the available forecasts were made before the SARS-CoV-2 pandemic broke out, so it can be expected that there will be fluctuations in this range. However, they probably cannot be long-term, as people develop various diseases regardless of the pandemic. However, extraordinary demand for materials should be expected, including in part biomaterials needed to produce security measures to prevent droplet infection of coronavirus. As public awareness grows, mainly among doctors, the market for these products will systematically grow. As expected, the demand for these protection measures will linger on the market for the long term. It is obviously related to the systematic increase in the demand for appropriate biomaterials, which will be necessary to produce such means of protecting the epidemiological safety of doctors, which will have to be used long after the official end of the pandemic. This part of this paper is dedicated to the issues of economic forecasts.

\section{Recapitulation and Final Remarks}

Health has been a concern of humankind since the beginning. Figure 40 symbolically illustrates medicine and dentistry's progress as its specific part dealing with the oral cavity. The dawn of medicine is depicted in an ancient votive relief ca 470-450 BC found in Thyrea, Greece, now in the National Archeological Museum in Athens, Greece, showing Asclepius with his sons Podalairius and Machaon and three daughters (Figure 40) [435,436]. In 
Greek mythology, Asclepius was the god of medical art, one of the heroes, as the son of the god Apollo and the nymph Koronis, husband of Epione (Soothing Pain) and father of Hygiea, Panacea, Iaso, Ajgle, Akeso, and the doctors Machaon, the internist and the surgeon Podalejrios. He is credited with raising the dead with a herb torn from a snake's mouth. Hence the staff of Asclepius entwined with a serpent is a symbol of medicine to this day. His Roman counterpart was Aesculapius. One of the first material pieces of evidence of deliberate medical intervention is the tooth of the lower right third molar (RM3) of the man from Villabruna, today in Italy, from the Late Upper Palaeolithic 14,000 years ago [437]. Hippocrates born c. 460 BC on the island of Kos, and died around 375 BC, was a Greek physician, nicknamed "the father of medicine". He is credited with the authorship, if not all. At least part of the extant work of the "Corpus Hippocraticum", a collection of about seventy medical writings from before the middle of the 4 th century BC. collected 100 years after the death of Hippocrates. Originally was written in Ionic Greek. The works of Hippocrates were first translated and printed in 1525 in Venice, Italy. Among the numerous papyri with medical content found at Oxyrnchos, Egypt, papyrus 4970 was found that testified to the use of the Hippocratic Oath in antiquity. A fragment of the oath on the 3rd-century Papyrus Oxyrhynchus 2547 [438-440] in English translation begins with the words: "I swear by Apollo Healer, by Asclepius, by Hygieia, by Panacea, and by all the gods and goddesses, making them my witnesses, that I will carry out, according to my ability and judgment, this oath and this indenture". A fragment of the original papyrus is shown in the picture. During the Renaissance in Italy, there was also an intense interest in the human body structure and medical knowledge progress. It was then that the first public postmortem examination took place in a purpose-built anatomical theatre at the University of Bologna, Italy by Mondino de Luzzi in 1315. His book "Anathomia corporis humani" written around 1316 [441], was the first in Europe since ancient times, starting with Galen, Aristotle, and Hippocrates. The knowledge accumulated in it was only verified over 200 years later in 1543 by a Flemish anatomist Andreas Vesalius in "De Humani Corporis Fabrica" [442,443]. At the turn of the 15th and 16th centuries, Leonardo $\mathrm{Da}$ Vinci became interested in anatomy through painting. The Renaissance celebrated the beauty of the human body, and Da Vinci wanted to understand its structure, function, and proportions and present it in his paintings as realistically as possible. From 1489, he performed the first anatomical examinations. In 1506 he performed the first autopsy, then examined over 30 corpses, and between 1510 and 1511, he prepared a series of about 240 drawings known as the "Anatomical Manuscript" [444]. Da Vinci's discoveries may have revolutionized medicine, but unfortunately, he did not publish his notes, and after his death, many drawings were lost and were not discovered until the 20th century. This cartridge is symbolically represented by the famous drawing "Le proporzioni del corpo umano secondo Vitruvio", disseminated around 1490, created in pencil and ink on paper $[445,446]$. The drawing shows a figure of a naked man in two superimposed positions, inscribed in a circle and a square, and a text drawn up in the so-called mirror writing. The last item in this figure is a copy of the Nobel Prize in Physiology or Medicine 2020 Diploma recently awarded to Prof. Michael Houghton of the University of Alberta in Edmonton, Canada "for the discovery of Hepatitis C virus." [447]. It symbolically closes the multi-thousand-year achievements of medicine that invariably serves human health.

Health and well-being have now become one of the 17 sustainable development goals set by the United Nations. It was included in the sphere of interests of many countries and international organizations, including the European Union. Progress is determined by the Human Development Index, significantly diversified in different countries, including the life expectancy index, which varies depending on the country from slightly over 50 to 84 years from birth. Even in the Organization for Economic Co-operation and Development OECD countries, the variation in different detailed indicators assessing health and health care level may differ fifty-fold. The differentiation in access to health care and the possibilities of prevention and treatment are much more varied. Due to many factors, including the index of the number of doctors related to the population and the 
degree of saturation of health care facilities with medical devices and products, and the level of technology supporting medicine. Despite such a long tradition and universal concern for societies' health and the great involvement of the intellect of many generations of philosophers and doctors, an unambiguous definition of health and disease has not been developed. It seems that the provision from the World Health Organization WHO constitution intuitively corresponds to the expectations, saying that health is "a state of complete physical, mental, and social well-being and not merely the absence of disease or infirmity". The COVID-19 pandemic, which significantly determines the organization of health care and the access of individual people to medical services, has a huge impact on societies' general health conditions worldwide. It is important to ensure proper safety for all people, especially doctors and medical staff, actively fighting the pandemic. It is achieved by two mutually complementary strategies-passive STOP and active SPEC created by authors, eliminating the threat at source, and the extensive worldwide vaccination campaign against the pandemic effects of the SARS-CoV-2 coronavirus.

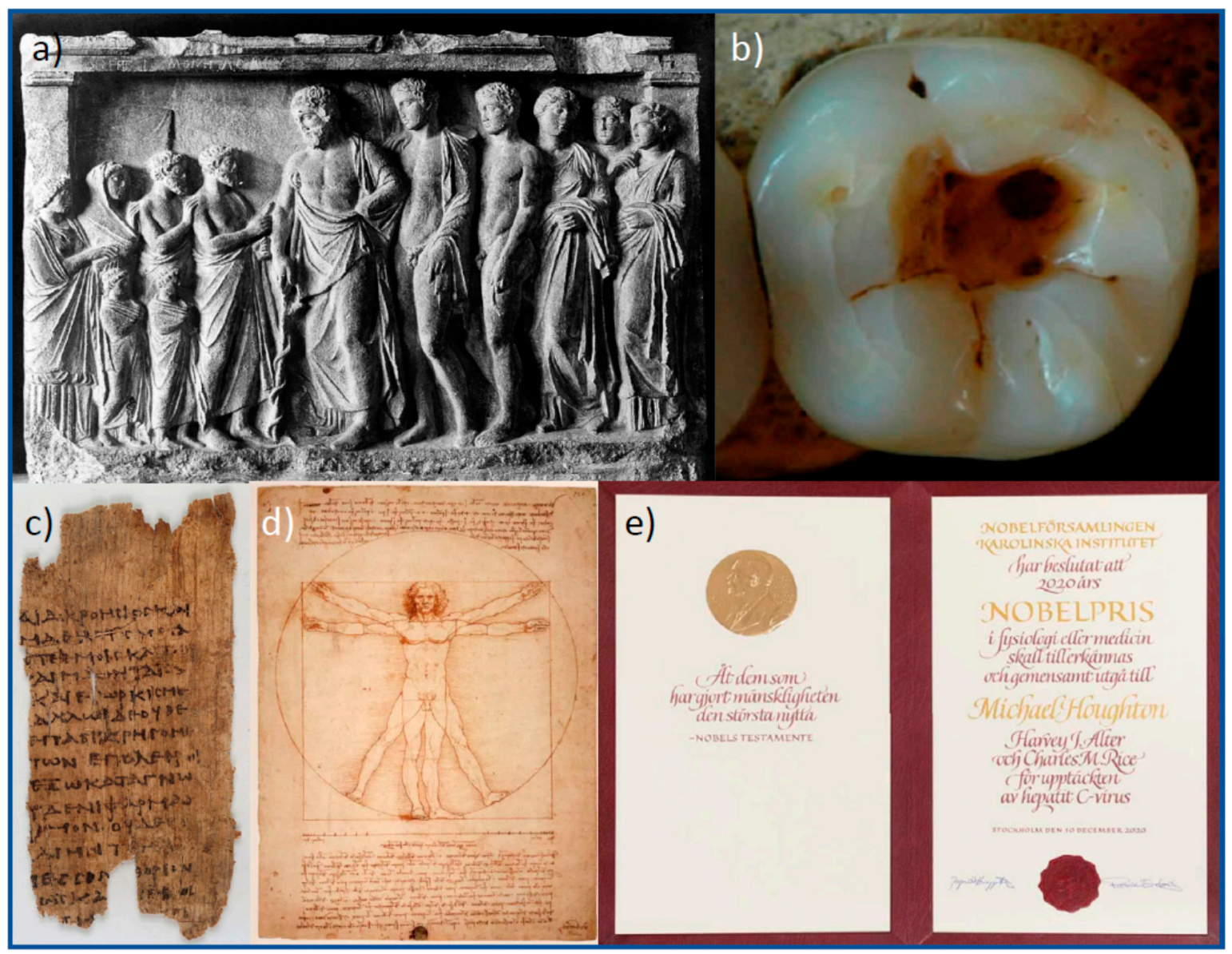

Figure 40. Diagram of the progress of medicine throughout history: (a) Greek votive relief ca 470-450 BC, found at Thyrea, Greece, now in the National Archeological Museum in Athens, Greece, depicting Asclepius as the god of medical art in Greek mythology with his sons Podalirius and Machaon and his three daughters, with supplicants; (b) tooth the lower right third molar (RM3) of the man from Villabruna, today in Italy, from the Late Upper Palaeolithic about 14,000 years ago with traces of intervention to repair the cavity and relieve pain; (c) a fragment of Papyrus Oxyrhynchus 2547, found in Egypt from the oath of Hippocrates dating from the 3rd-century BC; (d) the drawing "Le proporzioni del corpo umano secondo Vitruvio", created in pencil and ink on paper by Leonardo da Vinci and disseminated around 1490; (e) a copy of the Nobel Prize in Physiology or Medicine 2020 diploma recently awarded to Prof. Michael Houghton of the University of Alberta in Edmonton, Canada "for the discovery of Hepatitis C virus.". 
The current level of medical procedures, including diagnostics, prevention, and supportive convalescence procedures, requires an extremely significant share of medical devices, including many that are temporarily or permanently installed or implanted into the human body. Bioengineering, including medical, dental, and tissue engineering, combines collaborative and interdisciplinary issues focused on integrative applications solutions of the problems unanswered independently by engineering and physical/life science disciplines. Since this is an important area of engineering sciences, it is necessary to meet the current stage of the technological revolution of Industry 4.0. By analogy to the idea of Dentistry 4.0, the problem can be generalized to Bioengineering 4.0. It requires widespread use in designing and manufacturing medical devices, modern achievements of computerization, automation, robotization, and the use of all possibilities of computer-aided engineering, transmission, collection, and security of cyber-physical systems, resulting from the augmented holistic model Industry 4.0.

It should be noted that achieving such a high level in patients' health care requires constant cooperation between doctors and biomedical and dental engineers. A strong imperative resulting from this cooperation is mutual respect for the moral principles applicable to both these circles. The four basic ethical principles for doctors are inextricably intertwined with the five moral principles for engineers. The obligation to assist patients in treating their diseases requires using the latest technological achievements that can serve this purpose. On the contrary, not keeping up with technological progress in this area must be treated as an ethical tort. The use of various groups of medical devices requires careful compliance with the applicable legal provisions, referred to as notified body approval requirements. Only in a limited number of these devices is enough selfassessment sufficient.

Any product's manufacturing requires appropriate engineering design, currently most often computer-aided, with proper engineering material and properly designed technological processes. The manufacturing of medical devices most often involves the use of biomedical materials, simply called biomaterials. Biomaterials are a wide group of engineering materials, and less often also some natural ones, including metals, ceramics, polymers, composites, and porous materials with the required biocompatibility and harmony of interaction with living matter and the related prevention of the initiation of toxicological and immunological reactions and effects of irritation of the living tissues of the body. Depending on the expected functions and the medical device's location in the human body, including the implants or prosthetic restorations and the drug distribution systems, biomaterials can be classified according to various criteria. Additive manufacturing plays a special role in technological processes, as is illustrated in this paper by numerous examples from clinical practice.

It should be noted that the use of these advanced technologies requires detailed knowledge. It turns out that there are publications that prove that the technological process is being carried out incorrectly. It mainly concerns the use of too low a laser or electron beam density adequately and improper flow of protective gases. Such reasons can cause even a 2.5-fold reduction in the strength properties of medical devices, e.g., implants. As a result, hardly any materials are obtained with better properties than those manufactured conventionally, and on the contrary, these properties are even lowered below an acceptable level. Such activities, causing the patient to be exposed to unforeseen and/or premature wear of elements, e.g., implantable components manufactured inappropriately, must be treated as an ethical tort, clearly incriminating the physician and the engineer cooperating with him/her, unless a physician without proper engineering knowledge, tried to manufacture such elements himself/herself, taking full responsibility. On the other hand, appropriate technology brings great benefits to patients, consisting of simplifying and shortening burdensome medical procedures, reducing pain sensations, and proper extension of failure-free use of implanted medical and dental devices. 
The biomaterials market, both in orthopedic, dental, tissue engineering, regenerative medicine, and related cell therapies, is systematically growing. Depending on the sector, the compound annual growth rate CAGR in the next at least five years ranges from approx. 5.5 to approx. $32 \%$, and for the total of biomaterials, is expected at the level of almost $16 \%$. Certainly, the COVID-19 pandemic and the related decline in the economy in many countries and local lockdowns will weaken the growth rate. Still, in turn, the need for new safety measures resulting from the development of the pandemic and necessary to be used long after its end will increase.

Each part of this paper ends with a set of thoughts that indicate the current state of the considered aspects and trends and development prospects. Elements of the policy of a long and healthy life were indicated in the context of the ethical aspects of doctors' mission and cooperating with them engineers. An important element is the dynamically growing need to protect doctors and medical staff against the risk of SARS-CoV-2 coronavirus infection, which tends to persist for many years to come. It is related to the growing demand for biomaterials. Subsequently, the focus was on the relationship between the development of biomaterials and the current stage of progress of Industry 4.0 of the industrial revolution with the proposed general approach of Bioengineering 4.0. Numerous examples of clinical applications of biomaterials and advanced technologies, such as additive manufacturing, electrospinning, and atomic layer deposition, have been shown, richly illustrated by the results of materiallographic research. Forecasts for the development of global markets for biomaterials, regenerative medicine and tissue engineering were analyzed. The technological processes of producing and processing biomedical materials and the systematic increase in their global production are the determinants of implementing a long and healthy life policy.

Summing up the considerations presented in this paper, it should be stated that the implementation of the long and healthy life policy, declared by the United Nations and by many countries, requires very intensive development of bioengineering under the rules of the Industry 4.0 stage, which in turn is very dependent closely on the development of and increasing the global production of biomaterials and technological processes development of their production and processing.

Author Contributions: Conceptualization, literature review, presentation design, resources, data curation, software, formal analysis, practical verification, writing — original draft preparation, visualization, writing — review and editing, supervision, project administration-L.A.D., A.D.D.-D., L.B.D., funding acquisition-L.A.D. and L.B.D. All authors have read and agreed to the published version of the manuscript.

Funding: This research was not directly financed by external funding.

Note: The paper is prepared due to the sending of the projects applications no.: POIR.01.01.01-002393/20 cleanDENTworkspace-Antiviral (SARS-CoV-2) and antimicrobial repeatedly awarded at the international innovation fair, a breakthrough system for ensuring the asepsis of the dental, ENT and general medical practice, as well as full protection of medical personnel and patients undergoing oral procedures, 14.12.2020, and no: POIR.01.01.01-00-0694/20 ASKLEPIOS-IFIS/Implantological final immediate reconstruction - a system based on implants, in particular individual ones, manufactured based on own innovative design and production technology using 3D printing, 17.06.2020, and due to actually implement Project POIR.01.01-00-0485/16-00 on "IMSKA-MAT Innovative dental and maxillofacial implants manufactured using the innovative additive technology supported by computer-aided materials design ADD-MAT" realized by the Medical and Dental Engineering Center for Research, Design, and Production ASKLEPIOS in Gliwice, Poland. The project was implemented in 2017-2021 and is co-financed by the Operational Program Intelligent Development of the European Union.

Conflicts of Interest: The authors declare no conflict of interest. 


\section{References}

1. Meadows, D.H.; Meadows, D.L.; Randers, J.; Behrens, W.W., III. The Limits to Growth: A Report for the Club of Rome's Project on the Predicament of Mankind; A Potomac Associates Book; Universe Books: New York, USA, 1972. Available online: https: / / collections.dartmouth.edu/teitexts/meadows/diplomatic/meadows_ltg-diplomatic.html (accessed on 1 March 2021).

2. Holcombe, R.G. A theory of the theory of public goods. Rev. Austrian Econ. 1997, 10, 1-22. [CrossRef]

3. Brundtland, G.H. (Ed.) Report of the World Commission on Environment and Development (WCED): Our Common Future (Also Known As the Brundtland Report). United Nations. 1987. Available online: https://sustainabledevelopment.un.org/content/ documents/5987our-common-future.pdf (accessed on 1 March 2021).

4. The 17 Goals. Available online: https://sdgs.un.org/goals (accessed on 1 March 2021).

5. Proposal for a Regulation of the European Parliament and of the Council on the Establishment of a Programme for the Union's Action in the Field of Health—for the Period 2021-2027 and Repealing Regulation (EU) No 282/2014 ("EU4Health Programme"). Available online: https:/ / eur-lex.europa.eu/legal-content/EN/TXT/?uri=CELEX:52020PC0405 (accessed on 1 March 2021).

6. Constitution of the World Health Organization. Available online: https://www.who.int/governance/eb/who_constitution_en. pdf (accessed on 1 March 2021).

7. Jakab, Z. Designing the road to better health and well-being in Europe. In Proceedings of the 14th European Health Forum Gastein, Bad Hofgastein, Austria, 7 October 2011. Available online: https://www.euro.who.int/_data/assets/pdf_file/0003/1 52184/RD_Dastein_speech_wellbeing_07Oct.pdf (accessed on 1 March 2021).

8. EU Health Policy. Available online: https: / / ec.europa.eu/health/policies/overview_pl (accessed on 1 March 2021).

9. Dobrzański, L.A. The concept of biologically active microporous engineering materials and composite biological-engineering materials for regenerative medicine and dentistry. Arch. Mater. Sci. Eng. 2016, 80, 64-85. [CrossRef]

10. United Nations Development Programme, Human Development Reports, Human Development Index (HDI). Available online: http:/ /hdr.undp.org/en/indicators/138806\# (accessed on 1 March 2021).

11. Human Development Report 2020. The Next Frontier: Human Development and the Anthropocene. United Nations Development Programme. Available online: http:/ /hdr.undp.org/sites/default/files/hdr2020.pdf (accessed on 1 March 2021).

12. Malik, K. Director, Human Development Report Office, UNDP. Inaugural Mahbub ul Haq-Amartya Sen Lecture, University De Geneve. Advancing, Sustaining Human Progress: From Concepts to Policies. Available online: http://hdr.undp.org/sites/ default/files/malik_mahbubulhaqlecture_2014.pdf (accessed on 1 March 2021).

13. UNDP. Human Development Report 1990: Concept and Measurement of Human Development. 1990. Available online: http:/ / www.hdr.undp.org/en/reports/global/hdr1990 (accessed on 1 March 2021).

14. UNDP. Human Development Report 2010: The Real Wealth of Nations_Pathways to Human Development. 2010. Available online: http:/ /hdr.undp.org/en/content/human-development-report-2010 (accessed on 1 March 2021).

15. Inequality-Adjusted Human Development Index (IHDI). Available online: http://hdr.undp.org/en/content/inequality-adjustedhuman-development-index-ihdi (accessed on 1 March 2021).

16. Dobrzański, L.A.; Dobrzański, L.B.; Dobrzańska-Danikiewicz, A.D.; Dobrzańska, J. The Concept of Sustainable Development of Modern Dentistry. Processes 2020, 8, 1605. [CrossRef]

17. OECD. Health at a Glance 2019: OECD Indicators; OECD Publishing: Paris, France, 2019. [CrossRef]

18. Bernabé, E.; Masood, M.; Vujicic, M. The impact of out-of-pocket payments for dental care on household finances in low and middle income countries. BMC Public Health 2017, 17, 109. [CrossRef] [PubMed]

19. FDI World Dental Federation. Available online: https://www.fdiworlddental.org/about-fdi (accessed on 1 March 2021).

20. Holst, D.; Sheiham, A.; Petersen, P. Regulating entrepreneurial behaviour in oral care health services. In European Observatory on Health Care Systems Series: Regulating Entrepreneurial Behaviour in European Care Health Systems; Saltman, R., Busse, R., Mossialos, E., Eds.; Open University Press: Philadelphia, PA, USA, 2002; pp. 215-231.

21. Statistics Poland. Health and Health Care in 2019. Available online: https://stat.gov.pl/obszary-tematyczne/zdrowie/zdrowie/ zdrowie-i-ochrona-zdrowia-w-2019-roku,1,10.html (accessed on 1 March 2021).

22. Concepts of Disease and Health. Available online: https://plato.stanford.edu/entries/health-disease/ (accessed on 1 March 2021).

23. Cain, A.J. Thomas Sydenham, John Ray, and some contemporaries on species. Arch. Nat. Hist. 1999, 26, 55-83. [CrossRef] [PubMed]

24. Hippius, H.; Müller, N. The work of Emil Kraepelin and his research group in München. Eur. Arch. Psychiatry Clin. Neurosc. 2008, 258, 3-11. [CrossRef] [PubMed]

25. Whitbeck, C. Causation in Medicine: The Disease Entity Model. Philos. Sci. 1977, 44, 619-637. [CrossRef]

26. Snow, J. On Continuous Molecular Changes, More Particularly in their Relation to Epidemic Diseases. In Snow on Cholera; Frost, W.H., Ed.; Hafner: New York, NY, USA, 1965; pp. 147-175.

27. Carter, K.C. The Rise of Causal Theories of Disease; Ashgate: Burlington, VT, Canada, 2003.

28. Broome, M. Taxonomy and Ontology in Psychiatry: A survey of recent literature. Philos. Psychiatry Psychol. 2006, 13, 303-319. [CrossRef]

29. Green, J.A. Prescribing by Numbers; Johns Hopkins: Baltimore, MD, USA, 2007; Chapter 2.

30. Plutynski, A. Explaining Cancer; Oxford University Press: New York, NY, USA, 2018; Chapter 2.

31. Bloomfield, P. Moral Reality; Oxford University Press: New York, NY, USA, 2001. 
32. Boorse, C. On The Distinction Between Disease and Illness. Philos. Pub. Aff. 1975, 5, 49-68.

33. Ereshefsky, M. Defining 'Health' and 'Disease'. Stud. Hist. Philos. Biol. Biomed. Sci. 2009, 40, 221-227. [CrossRef] [PubMed]

34. Culver, C.M.; Gert, B. Philosophy in Medicine; Oxford University Press: New York, NY, USA, 1982.

35. Thagard, P. How Scientists Explain Disease; Princeton University Press: Princeton, NJ, USA, 1999.

36. Kennedy, I. The Unmasking of Medicine; Allen and Unwin: London, UK, 1983.

37. Brown, P. The Name Game: Toward A Sociology of Diagnosis. J. Mind Behav. 1990, 11, 385-406.

38. Kitcher, P. The Lives To Come: The Genetic Revolution and Human Possibilities, Revised Ed.; Simon \& Schuster: New York, NY, USA, 1997; pp. 208-209.

39. Boorse, C. What A Theory of Mental Health Should Be. J. Theory Soc. Behav. 1976, 6, 61-84. [CrossRef]

40. Boorse, C. Health as a Theoretical Concept. Philos. Sci. 1977, 44, 542-573. [CrossRef]

41. Boorse, C. A rebuttal on health. In What Is Disease? Humber, J.M., Almeder, R.F., Eds.; Humana Press: Totowa, NJ, USA, 1997; pp. 3-143.

42. Murphy, D. Psychiatry in the Scientific Image; MIT Press: Cambridge, MA, USA, 2006.

43. Hatfield, G. René Descartes. In Stanford Encyclopedia of Philosophy; Winter 2017, Edition; Zalta, E.N., Ed.; Metaphysics Research Lab, Stanford University: Stanford, CA, USA, 2017. Available online: https://plato.stanford.edu/archives/win2017/entries/ descartes/ (accessed on 1 March 2021).

44. Kulik, T.B. Zdrowie-Kategoria uniwersalna. Wych Fiz Zdrow 1996, 3, 103-105.

45. Manual of the International Statistical Classification of Diseases, Injuries, and Causes of Death: Based on the Recommendations of the Ninth Revision Conference, 1975, and Adopted by the Twenty-Ninth World Health Assembly, 1975 Revision. Available online: https: / apps.who.int/iris/handle/10665/40492 (accessed on 1 March 2021).

46. Firek, W. W stronę filozofii zdrowia. In Zdrowie I Jego Uwarunkowania; Mucha, D., Zięba, H., Eds.; PPWSZ: Nowy Targ, Poland, 2011; pp. 22-33.

47. Reznek, L. The Nature of Disease; Routledge: New York, NY, USA, 1987.

48. Glackin, S. Tolerance and illness: The politics of medical and psychiatric classification. J. Med. Philos. 2010, 35, 449-465. [CrossRef]

49. Barnes, E. The Minority Body; Oxford University Press: New York, NY, USA, 2016.

50. Amundson, R. Against Normal Function. Stud. Hist. Phil. Biol. Biomed. Sci. 2000, 31, 33-53. [CrossRef]

51. Inkpen, S.A. Health, Ecology and the Microbiome. eLife 2019, 8, e47626. [CrossRef] [PubMed]

52. Maszczak, T. Zdrowie jako wartość. Kult Fiz 2006, 9-12, 23.

53. Puchalski, K. Pojecie Świadomości Zdrowotnej. In Zdrowie W Świadomości Społecznej; KCPZMP: Łódź, Poland, $1997 ;$ p. 18.

54. Tatarkiewicz, W. O szczęściu; PWN: Warszawa, CA, USA, 1979; pp. 216-217.

55. Puchalski, K. Zdrowie Jako Wartość. In Zdrowie W Świadomości Społecznej; KCPZMP: Łódź, Poland, $1997 ;$ p. 71.

56. Díaz-Guerrero, R. Psychology of the Mexican: Culture and Personality; University of Texas Press: Austin, TX, USA, 1975.

57. Dobrzański, L.A.; Dobrzański, L.B.; Dobrzańska-Danikiewicz, A.D.; Dobrzańska, J.; Kraszewska, M. The synergistic ethics interaction with nanoengineering, dentistry and dental engineering. In Ethics in Nanotechnology; Jeswani, G., Van De Voorde, M., Eds.; De Gruyter: Berlin, Germany, 2020; (prepared for printing).

58. Dobrzański, L.A.; Dobrzański, L.B.; Dobrzańska-Danikiewicz, A.D.; Dobrzańska, J.; Kraszewska, M. Development prospects of the dentistry 4.0, dental engineering and nanotechnology triad towards ethical imperatives. In Ethics in Nanotechnology; Jeswani, G., Van De Voorde, M., Eds.; De Gruyter: Berlin, Germany, 2020; (prepared for printing).

59. Steinke, H. Der Hippokratische eid: Ein schwieriges erbe. Horizonte medizingeschichte, schweizerische ärztezeitung. Bull. Médecins Suisses Boll. Med. Svizz 2016, 97, 1699-1701.

60. Murgic, L.; Hébert, P.C.; Sovic, S.; Pavlekovic, G. Paternalism and autonomy: Views of patients and providers in a transitional (post-communist) country. BMC Med. Ethics. 2015, 29, 65. [CrossRef] [PubMed]

61. Will, J.F. A brief historical and theoretical perspective on patient autonomy and medical decision making: Part II: The autonomy model. Chest 2011, 139, 1491-1497. [CrossRef] [PubMed]

62. Baumann, A.; Audibert, G.; Guibet Lafaye, C.; Puybasset, L.; Mertes, P.M.; Claudot, F. Elective non-therapeutic intensive care and the four principles of medical ethics. J. Med. Ethics. 2013, 39, 139-142. [CrossRef] [PubMed]

63. Jotterand, F. The hippocratic oath and contemporary medicine: Dialectic between past ideals and present reality? J. Med. Philos. 2005, 30, 107-128. [CrossRef]

64. Gillon, R. Medical ethics: Four principles plus attention to scope. BMJ 1994, 309, 184. [CrossRef] [PubMed]

65. Beauchamp, T.L.; Childress, J.F. Principles of Biomedical Ethics, 8th ed.; Oxford University Press: New York, NY, USA, 2019.

66. Holm, S. Not just autonomy-The principles of American biomedical ethics. J. Med. Ethics. 1995, 21, 6. [CrossRef] [PubMed]

67. Beauchamp, T.L.; Childress, J.F. Principles of Biomedical Ethics, 1st ed.; Oxford University Press: New York, NY, USA, 1979.

68. Veatch, R.M. The impossibility of a morality internal to medicine. J. Med. Philos. A Forum. Bioeth. Philos. Med. 2001, 26, 621-642. [CrossRef]

69. Nash, D.A. Ethics in dentistry: Review and critique of principles of ethics and code of professional conduct. J. Am. Dent. Assoc. 1984, 109, 597-603. [CrossRef] [PubMed]

70. Seear, J.E.; Walters, L. Law and Ethics in Dentistry Paperback, 3rd ed.; Butterworth-Heinemann Ltd.: Oxford, UK, 1991.

71. Jessri, M.; Fatemitabar, S.A. Implication of ethical principles in chair-side dentistry. Iran. J. Allergy Asthma Immunol. 2007, 6 (Suppl. S5), 53-59. 
72. Nash, D.A. On ethics in the profession of dentistry and dental education. Eur. J. Dent. Educ. 2007, 11, 64-74. [CrossRef] [PubMed]

73. Covid-19. Available online: https://www.oed.com/view/Entry/88575495 (accessed on 1 March 2021).

74. Symptoms of Coronavirus. Available online: https://www.cdc.gov/coronavirus/2019-ncov/symptoms-testing/symptoms.html (accessed on 1 March 2021).

75. Coronavirus Disease (COVID-19). Available online: https://www.who.int/emergencies/diseases/novel-coronavirus-2019 / question-and-answers-hub / q-a-detail/coronavirus-disease-covid-19 (accessed on 1 March 2021).

76. Nussbaumer-Streit, B.; Mayr, V.; Dobrescu, A.I.; Chapman, A.; Persad, E.; Klerings, I.; Wagner, G.; Siebert, U.; Christof, C.; Zachariah, C.; et al. Quarantine alone or in combination with other public health measures to control COVID-19: A rapid review. Cochrane Database Syst. Rev. 2020, 4, 1-45. [CrossRef]

77. COVID-19 Dashboard by the Center for Systems Science and Engineering (CSSE) at Johns Hopkins University (JHU). Available online: https:/ /gisanddata.maps.arcgis.com/apps/opsdashboard/index.html\#/bda7594740fd40299423467b48e9ecf6 (accessed on 1 March 2021).

78. Interim Clinical Guidance for Management of Patients with Confirmed Coronavirus Disease (COVID-19). Available online: https:/ / www.cdc.gov/coronavirus/2019-ncov/hcp/clinical-guidance-management-patients.html (accessed on 1 March 2021).

79. Oran, D.P.; Topol, E.J. The Proportion of SARS-CoV-2 Infections That Are Asymptomatic. A Systematic Review. Ann. Intern. Med. 2021, M20, 6976. [CrossRef]

80. Transmission of COVID-19. Available online: https:/ / www.ecdc.europa.eu/en/covid-19/latest-evidence/transmission (accessed on 1 March 2021).

81. Long-Term Effects of COVID-19. Available online: https://www.cdc.gov/coronavirus/2019-ncov/long-term-effects.html (accessed on 1 March 2021).

82. Coronavirus Disease: COVID-19-Appendices. Available online: https://www.cdc.gov/coronavirus/2019-ncov/php/contacttracing/contact-tracing-plan/appendix.html\#contact (accessed on 1 March 2021).

83. Quarantine for Coronavirus (COVID-19). Available online: https://www.health.gov.au/news/health-alerts/novel-coronavirus2019-ncov-health-alert/how-to-protect-yourself-and-others-from-coronavirus-covid-19/ quarantine-for-coronavirus-covid19\#what-is-a-close-contact (accessed on 1 March 2021).

84. How COVID-19 Spreads. Available online: https://www.cdc.gov/coronavirus/2019-ncov/prevent-getting-sick/how-covidspreads.html (accessed on 1 March 2021).

85. Coronavirus Disease (COVID-19): How Is It Transmitted? Available online: https://www.who.int/news-room/q-a-detail/ coronavirus-disease-covid-19-how-is-it-transmitted (accessed on 1 March 2021).

86. Coronavirus Disease (COVID-19): Frequently Asked Questions. Available online: https://www.cdc.gov/coronavirus/2019 -ncov / faq.html (accessed on 1 March 2021).

87. Transmission of SARS-CoV-2: Implications for Infection Prevention Precautions. Available online: https://www.who.int/newsroom/commentaries/detail/transmission-of-sars-cov-2-implications-for-infection-prevention-precautions (accessed on $1 \mathrm{March}$ 2021).

88. Clinical Questions about COVID-19: Questions and Answers. Available online: https://www.cdc.gov/coronavirus/2019-ncov/ hcp / faq.html (accessed on 1 March 2021).

89. Dobrzański, L.A.; Dobrzański, L.B.; Dobrzańska-Danikiewicz, A.D.; Dobrzańska, J.; Rudziarczyk, K.; Achtelik-Franczak, A. Non-Antagonistic Contradictoriness of the Progress of Advanced Digitized Production with SARS-CoV-2 Virus Transmission in the Area of Dental Engineering. Processes 2020, 8, 1097. [CrossRef]

90. Funk, C.D.; Laferrière, C.; Ardakani, A. A Snapshot of the Global Race for Vaccines Targeting SARS-CoV-2 and the COVID-19 Pandemic. Front. Pharm. 2020, 11, 937. [CrossRef] [PubMed]

91. Jia, Z.; Barbier, L.; Stuart, H.; Amraei, M.; Pelech, S.; Dennis, J.W.; Metalnikov, P.; O’Donnell, P.; Nabi, I.R. Tumor cell pseudopodial protrusions. Localized signaling domains coordinating cytoskeleton remodeling, cell adhesion, glycolysis, RNA translocation, and protein translation. J. Biol. Chem. 2005, 280, 30564-30573. [CrossRef] [PubMed]

92. Li, X.; Geng, M.; Peng, Y.; Meng, L.; Lu, S. Molecular immune pathogenesis and diagnosis of COVID-19. J. Pharm. Anal. 2020, 10, 102-108. [CrossRef] [PubMed]

93. How Furin and ACE2 Interact with the Spike on SARS-CoV-2. Available online: https://www.assaygenie.com/how-furin-andace2-interact-with-the-spike-on-sarscov2 (accessed on 1 March 2021).

94. Zhou, P.; Yang, X.L.; Wang, X.G.; Hu, B.; Zhang, L.; Zhang, W.; Si, H.-R.; Zhu, Y.; Li, B.; Huang, C.-L.; et al. A pneumonia outbreak associated with a new coronavirus of probable bat origin. Nature 2020, 579, 270-273. [CrossRef] [PubMed]

95. Letko, M.; Munster, V. Functional assessment of cell entry and receptor usage for lineage B $\beta$-coronaviruses, including 2019-nCoV. bioRxiv 2020, 1-26. [CrossRef]

96. Letko, M.; Marzi, A.; Munster, V. Functional assessment of cell entry and receptor usage for SARS-CoV-2 and other lineage B betacoronaviruses. Nat. Microbiol. 2020, 5, 562-569. [CrossRef] [PubMed]

97. Genomic Characterization of the 2019 Novel Coronavirus. Available online: https://www.jwatch.org/na50823/2020/02/06/ genomic-characterization-2019-novel-coronavirus (accessed on 1 March 2021).

98. Gralinski, L.E.; Menachery, V.D. Return of the Coronavirus: 2019-nCoV. Viruses 2020, 12, 135. [CrossRef] [PubMed]

99. Lu, R.; Zhao, X.; Li, J.; Niu, P.; Yang, B.; Wu, H.; Wang, W.; Song, H.; Huang, B.; Zhu, N.; et al. Genomic characterisation and epidemiology of 2019 novel coronavirus: Implications for virus origins and receptor binding. Lancet 2020, 395, 565-574. [CrossRef] 
100. Walls, A.C.; Park, Y.J.; Tortorici, M.A.; Wall, A.; McGuire, A.T.; Veesler, D. Structure, Function, and Antigenicity of the SARS-CoV-2 Spike Glycoprotein. Cell 2020, 181, 281-292.e6. [CrossRef] [PubMed]

101. Zheng, Y.Y.; Ma, Y.T.; Zhang, J.Y.; Xie, X. COVID-19 and the cardiovascular system. Nat. Rev. Cardiol. 2020, 17, 259-260. [CrossRef] [PubMed]

102. Lamers, M.M.; Beumer, J.; van der Vaart, J.; Knoops, K.; Puschhof, J.; Breugem, T.I.; Ravelli, R.B.G.; Paul van Schayck, J.; Mykytyn, A.Z.; Duimel, H.Q.; et al. SARS-CoV-2 productively infects human gut enterocytes. Science 2020, 369, 50-54. [CrossRef] [PubMed]

103. Monteil, V.; Kwon, H.; Prado, P.; Hagelkrüys, A.; Wimmer, R.A.; Stahl, M.; Leopoldi, A.; Garreta, E.; Hurtado Del Pozo, C.; Prosper, F.; et al. Inhibition of SARS-CoV-2 Infections in Engineered Human Tissues Using Clinical-Grade Soluble Human ACE2. Cell 2020, 181, 905-913.e7. [CrossRef]

104. Shang, J.; Wan, Y.; Luo, C.; Ye, G.; Geng, Q.; Auerbach, A.; Li, F. Cell entry mechanisms of SARS-CoV-2. Proc. Natl. Acad. Sci. USA 2020, 117, 11727-11734. [CrossRef] [PubMed]

105. Coutard, B.; Valle, C.; de Lamballerie, X.; Canard, B.; Seidah, N.G.; Decroly, E. The spike glycoprotein of the new coronavirus 2019-nCoV contains a furin-like cleavage site absent in CoV of the same clade. Antivir. Res. 2020, 176, 104742. [CrossRef] [PubMed]

106. Li, H.; Wu, C.; Yang, Y.; Liu, Y.; Zhang, P.; Wang, Y.; Wang, Q.; Xu, Y.; Li, M.; Zheng, M.; et al. Furin, a potential therapeutic target for COVID-19. ChinaXiv 2020, 1-34. [CrossRef]

107. Thailand Medical News. Breaking! Latest Coronavirus Research Reveals That The Virus Has Mutated Gene Similar To HIV and Is 1,000 Times More Potent. Available online: https:/ / www.thailandmedical.news/news/breaking!-latestcoronavirus-researchreveals-that-the-virus-has-mutated-gene-similar-to-hiv-and-is-1,000-times-more-potent- (accessed on 1 March 2021).

108. Harcourt, J.; Tamin, A.; Lu, X.; Kamili, S.; Sakthivel, S.K.; Murray, J.; Queen, K.; Tao, Y.; Paden, C.R.; Zhang, J.; et al. Severe Acute Respiratory Syndrome Coronavirus 2 from Patient with Coronavirus Disease, United States. Emerg. Infect. Dis. 2020, 26, 1266-1273. [CrossRef] [PubMed]

109. Ou, X.; Liu, Y.; Lei, X.; Li, P.; Mi, D.; Ren, L.; Guo, L.; Guo, R.; Chen, T.; Hu, J.; et al. Characterization of spike glycoprotein of SARS-CoV-2 on virus entry and its immune cross-reactivity with SARS-CoV. Nat. Commun. 2020, 11, 1620. [CrossRef] [PubMed]

110. Jasiński, G. Koronawirus Zakaża skuteczniej niż SARS? Nowe fakty ws. wirusa z Chin. Available online: https: / / www.rmf24.pl/raporty/raport-koronawirus-z-chin/najnowsze-fakty/news-koronawirus-zakaza-skuteczniej-niz-sarsnowe-fakty-ws-wirusa,nId,4352687 (accessed on 1 March 2021).

111. Huggins, D.J. Structural analysis of experimental drugs binding to the SARS-CoV-2 target TMPRSS2. J. Mol. Graph. Model. 2020, 100, 107710. [CrossRef] [PubMed]

112. Hoffmann, M.; Kleine-Weber, H.; Schroeder, S.; Krüger, N.; Herrler, T.; Erichsen, S.; Schiergens, T.S.; Herrler, G.; Wu, N.H.; Nitsche, A.; et al. SARS-CoV-2 Cell Entry Depends on ACE2 and TMPRSS2 and Is Blocked by a Clinically Proven Protease Inhibitor. Cell 2020, 181, 271-280.e8. [CrossRef] [PubMed]

113. Harrison, C. Coronavirus puts drug repurposing on the fast track. Nat. Biotechnol. 2020, 38, 379-381. [CrossRef] [PubMed]

114. Thailand Medical News. Coronavirus Drug Research: German Researchers Identify Japanese Drug, Camostat Mesylate That Could Be Repurposed To Treat Covid-19. Available online: https://www.thailandmedical.news/news/coronavirus-drugresearch-german-researchers-identify-japanese-drug,-camostat-mesylate-that-could-be-repurposed-to-treat-covid-19 (accessed on 1 March 2021).

115. Xu, H.; Zhong, L.; Deng, J.; Peng, J.; Dan, H.; Zeng, X.; Li, T.; Chen, Q. High expression of ACE2 receptor of 2019-nCoV on the epithelial cells of oral mucosa. Int. J. Oral. Sci. 2020, 12, 8. [CrossRef] [PubMed]

116. Yan, T.; Xiao, R.; Lin, G. Angiotensin-converting enzyme 2 in severe acute respiratory syndrome coronavirus and SARS-CoV-2: A double-edged sword? FASEB J. 2020, 34, 6017-6026. [CrossRef] [PubMed]

117. Bharat, A.; Querrey, M.; Markov, N.S.; Kim, S.; Kurihara, C.; Garza-Castillon, R.; Manerikar, A.; Shilatifard, A.; Tomic, R.; Politanska, Y.; et al. Lung transplantation for patients with severe COVID-19. Sci. Transl. Med. 2020, 12, eabe4282. [CrossRef] [PubMed]

118. WHO Europe. Postępowanie Kliniczne W Ostrym Zakażeniu Dróg Oddechowych O Ciężkim Przebiegu (Sari) W Przypadku Podejrzenia Choroby COVID-9. Available online: https://apps.who.int/iris/bitstream/handle/10665/331809/WHO-2019 -nCoV-clinical-2020.4-pol.pdf (accessed on 1 March 2021).

119. Dobrzańska-Danikiewicz, A.D. Metodologia komputerowo zintegrowanego prognozowania rozwoju inżynierii powierzchni materiałów. In Open Access Library 1(7); Dobrzański, L.A., Ed.; International OCSCO World Press: Gliwice, Poland, 2012; pp. $1-289$.

120. Dobrzańska-Danikiewicz, A.D. Księga technologii krytycznych kształtowania struktury i własności powierzchni materiałów inżynierskich. In Open Access Library 8(26); Dobrzański, L.A., Ed.; International OCSCO World Press: Gliwice, Poland, 2013; pp. 1-823.

121. Dobrzański, L.A.; Dobrzańska-Danikiewicz, A.D. Inżynieria powierzchni materiałów: Kompendium wiedzy i podręcznik akademicki. In Open Access Library VIII(1); Dobrzański, L.A., Ed.; International OCSCO World Press: Gliwice, Poland, 2018; pp. 1-1138.

122. Morrison, A.; Wensley, R. Boxing up or Boxed in?: A Short History of the Boston Consulting Group Share/Growth Matrix. J. Mark. Manag. 1991, 7, 105-129. [CrossRef] 
123. Beaumont, P. Covid-19 Vaccine: Who Are Countries Prioritising for First Doses? Available online: https: / / www.theguardian. com/world/2020/nov/18/ covid-19-vaccine-who-are-countries-prioritising-for-first-doses (accessed on 1 March 2021).

124. Coronavirus (COVID-19) Vaccinations-Ststistics and Research. Available online: https://ourworldindata.org/covidvaccinations (accessed on 23 February 2021).

125. Geter, A.; Herron, A.R.; Sutton, M.Y. HIV-Related Stigma by Healthcare Providers in the United States: A Systematic Review. Aids. Patient Care Stds. 2008, 32, 418-424. [CrossRef] [PubMed]

126. Krishnaratne, S.; Hensen, B.; Cordes, J.; Enstone, J.; Hargreaves, J.R. Interventions to strengthen the HIV prevention cascade: A systematic review of reviews. Lancet Hiv. 2016, 3, e307-e317. [CrossRef]

127. Coates, T.J.; Richter, L.; Caceres, C. Behavioural strategies to reduce HIV transmission: How to make them work better. Lancet 2008, 372, 669-684. [CrossRef]

128. Hurley, S.F.; Jolley, D.J.; Kaldor, J.M. Effectiveness of needle-exchange programmes for prevention of HIV infection. Lancet 1997, 349, 1797-1800. [CrossRef]

129. Vlahov, D.; Junge, B. The role of needle exchange programs in HIV prevention. Public Health Rep. 1998, 113 (Suppl. S1), 75-80. [PubMed]

130. Wszystko O Wariantach Brytyjskim, Brazylijskim I Południowoafrykańskim. Available online: https://www.medonet. pl/koronawirus / to-musisz-wiedziec, wariant-covid-19-brytyjski--brazylijski-i-poludniowoafrykanski--co-warto-wiedziec, artykul,88341446.html (accessed on 1 March 2021).

131. Bioengineering. Available online: https://bioe.uw.edu/wp-content/uploads/2013/05/bioengineering-vs-other-disciplinesalt1.png (accessed on 1 March 2021).

132. Dobrzański, L.A. Introductory Chapter: Multi-Aspect Bibliographic Analysis of the Synergy of Technical, Biological and Medical Sciences Concerning Materials and Technologies Used for Medical and Dental Implantable Devices. In Biomaterials in Regenerative Medicine; Dobrzański, L.A., Ed.; IntechOpeen: Rijeka, Croatia, 2018; pp. 1-43. [CrossRef]

133. Dobrzański, L.A.; Dobrzański, L.B. Approach to the Design and Manufacturing of Prosthetic Dental Restorations According to the Rules of Industry 4.0. Mater. Perform. Charact 2020, 9, 394-476. [CrossRef]

134. Dobrzański, L.A.; Dobrzański, L.B. Dentistry 4.0 Concept in the Design and Manufacturing of Prosthetic Dental Restorations. Processes 2020, 8, 525. [CrossRef]

135. Dobrzański, L.A. Role of materials design in maintenance engineering in the context of industry 4.0 idea. J. Achiev. Mater. Manuf. Eng. 2019, 96, 12-49. [CrossRef]

136. Dobrzański, L.A.; Dobrzańska-Danikiewicz, A.D. Why Are Carbon-Based Materials Important in Civilization Progress and Especially in the Industry 4.0 Stage of the Industrial Revolution. Mater. Perform. Charact 2019, 8, 337-370. [CrossRef]

137. Dobrzański, L.A.; Dobrzański, L.B.; Dobrzańska-Danikiewicz, A.D. Overview of conventional technologies using the powders of metals, their alloys and ceramics in Industry 4.0 stage. J. Achiev. Mater. Manuf. Eng. 2020, 98, 56-85. [CrossRef]

138. Dobrzański, L.A.; Dobrzański, L.B.; Dobrzańska-Danikiewicz, A.D.; Kraszewska, M. Manufacturing powders of metals, their alloys and ceramics and the importance of conventional and additive technologies for products manufacturing in Industry 4.0 stage. Arch. Mater. Sci. Eng. 2020, 102, 13-41. [CrossRef]

139. Dobrzański, L.A.; Dobrzański, L.B.; Achtelik-Franczak, A.; Dobrzańska, J. Application Solid Laser-Sintered or Machined Ti6Al4V Alloy in Manufacturing of Dental Implants and Dental Prosthetic Restorations According to Dentistry 4.0 Concept. Processes 2020, 8, 664. [CrossRef]

140. Dobrzański, L.A. Autorska koncepcja rozwoju implanto-skafoldów oraz materiałów biologiczno-inżynierskich do aplikacji w medycynie i stomatologii. In Metalowe Materiaty Mikroporowate I Lite Do Zastosowań Medycznych I Stomatologicznych; Open Access Library VII(1); Dobrzański, L.A., Dobrzańska-Danikiewicz, A.D., Eds.; International OCSCO World Press: Gliwice, Poland, 2017; pp. $535-580$.

141. Dobrzański, L.A.; Dobrzańska-Danikiewicz, A.D.; Achtelik-Franczak, A.; Szindler, M. Structure and properties of the skeleton microporous materials with coatings inside the pores for medical and dental applications. In Frontiers in Materials Processing, Applications, Research and Technology; Muruganant, M., Chirazi, A., Raj, B., Eds.; Springer Nature: Singapore, 2018; pp. 297-320. [CrossRef]

142. Dobrzański, L.A.; Dobrzańska-Danikiewicz, A.D.; Gaweł, T.G.; Achtelik-Franczak, A. Selective laser sintering and melting of pristine titanium and titanium Ti6Al4V alloy powders and selection of chemical environment for etching of such materials. Arch. Metall. Mater. 2015, 60, 2039-2045. [CrossRef]

143. Dobrzański, L.A. Overview and general ideas of the development of constructions, materials, technologies and clinical applications of scaffolds engineering for regenerative medicine. Arch. Mater. Sci. Eng. 2014, 69, 53-80.

144. Dobrzański, L.A.; Achtelik-Franczak, A. Struktura i własności tytanowych szkieletowych materiałów mikroporowatych wytworzonych metodą selektywnego spiekania laserowego do zastosowań w implantologii oraz medycynie regeneracyjnej. In Metalowe Materiaty Mikroporowate I Lite Do Zastosowań Medycznych I Stomatologicznych; Open Access Library VII(1); Dobrzański, L.A., Dobrzańska-Danikiewicz, A.D., Eds.; International OCSCO World Press: Gliwice, Poland, 2017; pp. 186-244.

145. Dobrzański, L.A.; Dobrzańska-Danikiewicz, A.D.; Malara, P.; Gawel, T.G.; Dobrzański, L.B.; Achtelik-Franczak, A. Fabrication of scaffolds from Ti6Al4V powders using the computer aided laser method. AMM 2015, 60, 1065-1070. [CrossRef]

146. Dobrzański, L.A. Metale i ich stopy. In Open Access Library VII(2); Dobrzański, L.A., Ed.; International OCSCO World Press: Gliwice, Poland, 2017; pp. 1-982. 
147. Dobrzański, L.A.; Achtelik-Franczak, A. Struktura i własności materiałów kompozytowych do zastosowań medycznych o osnowie odlewniczych stopów aluminium wzmacnianych tytanowymi szkieletami wytworzonymi metoda selektywnego spiekania laserowego. In Metalowe Materiały Mikroporowate I Lite Do Zastosowań Medycznych I Stomatologicznych; Open Access Library VII(1); Dobrzański, L.A., Dobrzańska-Danikiewicz, A.D., Eds.; International OCSCO World Press: Gliwice, Poland, 2017; pp. 376-433.

148. Dobrzański, L.A. Stan wiedzy o materiałach stosowanych w implantologii oraz medycynie regeneracyjnej. In Metalowe Materiaty Mikroporowate I Lite Do Zastosowań Medycznych I Stomatologicznych; Open Access Library, VII(1); Dobrzański, L.A., DobrzańskaDanikiewicz, A.D., Eds.; International OCSCO World Press: Gliwice, Poland, 2017; pp. 117-120.

149. Dobrzański, L.A. Applications of newly developed nanostructural and microporous materials in biomedical, tissue and mechanical engineering. Arch. Mater. Sci. Eng. 2015, 76, 53-114.

150. Nowacki, J.; Dobrzański, L.A.; Gustavo, F. Implanty śródszpikowe w osteosyntezie kości długich. In Open Access Library 11(17); Dobrzański, L.A., Ed.; International OCSCO World Press: Gliwice, Poland, 2012; pp. 1-150.

151. Dobrzańska-Danikiewicz, A.D.; Gaweł, T.G.; Kroll, L.; Dobrzański, L.A. Nowe porowate materiały kompozytowe metalowopolimerowe wytwarzane z udziałem selektywnego stapiania laserowego. In Metalowe Materiaty Mikroporowate I Lite Do Zastosowań Medycznych I Stomatologicznych; Open Access Library, VII(1); Dobrzański, L.A., Dobrzańska-Danikiewicz, A.D., Eds.; International OCSCO World Press: Gliwice, Poland, 2017; pp. 245-288.

152. Dobrzański, L.A.; Dobrzańska-Danikiewicz, A.D. (Eds.) Metalowe Materiaty Mikroporowate I Lite Do Zastosowań Medycznych I Stomatologicznych; Open Access Library VII(1); International OCSCO World Press: Gliwice, Poland, 2017; pp. 1-580.

153. Dobrzański, L.A.; Matula, G.; Dobrzańska-Danikiewicz, A.D.; Malara, P.; Kremzer, M.; Tomiczek, B.; Kujawa, M.; Hajduczek, E.; Achtelik-Franczak, A.; Dobrzański, L.B.; et al. Composite materials infiltrated by aluminium alloys based on porous skeletons from alumina, Mullite and titanium produced by powder metallurgy techniques. In Powder Metallurgy—Fundamentals and Case Studies; Dobrzański, L.A., Ed.; IntechOpen: Rijeka, Croatia, 2017; pp. 95-137. [CrossRef]

154. Dobrzański, L.A. (Ed.) Polymer Nanofibers Produced by Electrospinning Applied in Regenerative Medicine; Open Access Library V(3); International OCSCO World Press: Gliwice, Poland, 2015; pp. 1-168.

155. Dobrzański, L.A.; Dobrzańska-Danikiewicz, A.D.; Achtelik-Franczak, A.; Dobrzański, L.B.; Hajduczek, E.; Matula, G. Fabrication Technologies of the Sintered Materials Including Materials for medical and dental application. In Powder Metallurgy-Fundamentals and Case Studies; Dobrzański, L.A., Ed.; IntechOpen: Rijeka, Croatia, 2017; pp. 17-52. [CrossRef]

156. Dobrzański, L.A. (Ed.) Powder Metallurgy—Fundamentals and Case Studies; IntechOpen: Rijeka, Croatia, 2017 ; pp. 1-392.

157. Dobrzańska-Danikiewicz, A.D.; Dobrzański, L.A.; Szindler, M.; Achtelik-Franczak, A.; Dobrzański, L.B. Obróbka powierzchni materiałów mikroporowatych wytworzonych metodą selektywnego spiekania laserowego w celu uefektywnienia proliferacji żywych komórek. In Metalowe Materiaty Mikroporowate I Lite Do Zastosowań Medycznych I Stomatologicznych; Open Access Library, VII(1); Dobrzański, L.A., Dobrzańska-Danikiewicz, A.D., Eds.; International OCSCO World Press: Gliwice, Poland, 2017; pp. 289-375.

158. Dobrzański, L.A. Korszerú mérnöki anyagok kutatásának nanotechnológiai aspektusai. Miskolci Egy. Multidiszcip. Tudományok 2016, 6, 21-44.

159. Dobrzański, L.A.; Dobrzańska-Danikiewicz, A.D.; Achtelik-Franczak, A.; Dobrzański, L.B.; Szindler, M.; Gawel, T.G. Porous selective laser melted Ti and Ti6Al4V materials for medical applications. In Powder Metallurgy_Fundamentals and Case Studies; Dobrzański, L.A., Ed.; IntechOpen: Rijeka, Croatia, 2017; pp. 161-181. [CrossRef]

160. Davis, M. Thinking Like an Engineer: Studies in the Ethics of a Profession; Oxford University Press: New York, NY, USA, 1998.

161. Davis, M. Engineering Ethics; Routledge: London, UK, 2005. [CrossRef]

162. Martin, M.W.; Schinzinger, R. Ethics in Engineering, 4th ed.; McGraw-Hill: Boston, MA, USA, 2005.

163. Harris, C.E.; Pritchard, M.S.; Rabins, M.J. Engineering Ethics: Concepts and Cases, 4th ed.; Wadsworth: Belmont, TN, USA, 2008.

164. Hansson, S.O. Ethical Criteria of Risk Acceptance. Erkenntnis 2003, 59, 291-309. [CrossRef]

165. Regulation (EU) $2017 / 745$ of the European Parliament and of the Council on Medical Devices, Amending Directive 2001/83/EC, Regulation (EC) No 178/2002 and Regulation (EC) No 1223/2009 and Repealing Council Directives 90/385/EEC and 93/42/EEC. Available online: https:/ / eur-lex.europa.eu/legal-content/EN/TXT/PDF/?uri=CELEX:32017R0745 (accessed on 1 March 2021).

166. Dobrzański, L.A.; Dobrzańska-Danikiewicz, A.D. Applications of Laser Processing of Materials in Surface Engineering in the Industry 4.0 Stage of the Industrial Revolution. Mater. Perform. Charact 2019, 8, 1091-1129. [CrossRef]

167. Dobrzański, L.A. Effect of heat and surface treatment on the structure and properties of the Mg-Al-Zn-Mn casting alloys. In Magnesium and Its Alloys; Dobrzański, L.A., Totten, G.E., Bamberger, M., Eds.; CRC Press: Boca Raton, FL, USA, 2019 ; pp. 91-202.

168. Dobrzański, L.A. Structural Phenomena Accompanying the Production of Composite and Nanocomposite Materials Using Selected Technologies. In Proceedings of the 22nd Physical Metallurgy and Materials Science Conference: Advanced Materials and Technologies, Bukowina Tatrzańska, Poland, 9-12 June 2019.

169. Dobrzański, L.A. Stage 4.0 of the Technological Revolution in the Context of the Development of Engineering E Dental Materials; Lviv Polytechnic National University: Lviv, Ukraine, 2019.

170. Dobrzański, L.A. Rola inżynierii materiałowej w etapie 4.0 rewolucji technologicznej. In Proceedings of the the 24th Seminar of the Polish Society of Materials Science, Jachranka, Poland, 12-15 May 2019.

171. Dobrzański, L.A. The Importance of Materials Engineering in Stage 4.0 of the Technological Revolution; Institute of Fundamental Technological Research: Warsaw, Poland, 27 May 2019. 
172. Dobrzański, L.A. Role of Materials Design in Maintenance Engineering in the Context of Industry 4.0 Idea. In Proceedings of the the International Maintenance Technologies Congress and Exhibition, Denizli, Turkey, 26-28 September 2019.

173. Jose, R.; Ramakrishna, S. Materials 4.0: Materials Big Data Enabled Materials Discovery. Appl. Mat. Today 2018, 10, 127-132. [CrossRef]

174. Dobrzański, L.A. Komputerowa nauka o materiałach jako metoda projektowania współczesnych materiałów i produktów inżynierskich. In Seminary of Research and Education Programmes in Materials Engineering; Polish Society of Materials Science: Myczkowce, Poland, 2004; pp. 55-88.

175. Ruehle, M.; Dosch, H.; Mittemeijer, E.; van de Voorde, M.H. (Eds.) European White Book on Fundamental Research in Materials Science; Max-Planck-Institute für Metallforschung: Stuttgart, Germany, 2001.

176. Kagermann, H.; Wahlster, W.; Helbig, J. Recommendations for Implementing the Strategic Initiative INDUSTRIE 4.0: Final Report of the Industrie 4.0 Working Group; Federal Ministry of Education and Research: Bonn, Germany, 2013.

177. Kagermann, H. Chancen Von Industrie 4.0 Nutzen. In Industrie 4.0 in Produktion, Automatisierung und Logistik; Springer Fachmedien Wiesbaden: Wiesbaden, Germany, 2014; pp. 603-614.

178. Hermann, M.; Pentek, T.; Otto, B. Design Principles for Industrie 4.0 Scenarios: A Literature Review; Technische Universität Dortmund: Dortmund, Germany, 2015.

179. Rüßmann, M.; Lorenz, M.; Gerbert, P.; Waldner, M.; Justus, J.; Engel, P.; Harnisch, M. Industry 4.0: The Future of Productivity and Growth in Manufacturing Industries; Boston Consulting Group: Boston, MA, USA, 2015.

180. European Commission. Commission Sets Out Path to Digitise European Industry. Available online: https://ec.europa.eu/ growth/content/commission-sets-out-path-digitise-european-industry-0_en (accessed on 1 March 2021).

181. Danieluk, K. Digital Innovation Hubs on Smart Factories in New EU Member States. Available online: https:/ / ec.europa.eu/ futurium/en/implementing-digitising-european-industry-actions/digital-innovation-hubs-smart-factories-new-eu (accessed on 1 March 2021).

182. Lu, B.H.; Bateman, R.J.; Cheng, K. RFID Enabled Manufacturing: Fundamentals, Methodology and Applications. Int. J. Agil. Syst. Manag. 2006, 1, 73-92. [CrossRef]

183. Giusto, D.; Iera, A.; Morabito, G.; Atzori, L. (Eds.) The Internet of Things; Springer: New York, NY, USA, 2010.

184. Zhu, Q.; Wang, R.; Chen, Q.; Liu, Y.; Qin, W. IOT Gateway: Bridging Wireless Sensor Networks into Internet of Things. In Proceedings of the 2010 IEEE/IFIP International Conference on Embedded and Ubiquitous Computing, Hong Kong, China, 11-13 December 2010; The Institute of Electrical and Electronics Engineers: Piscataway, NJ, USA, 2010; pp. 347-352.

185. Wan, J.; Yan, H.; Liu, Q.; Zhou, K.; Lu, R.; Li, D. Enabling Cyber-Physical Systems with Machine-to-Machine Technologies. Int. J. Ad. Hoc. Ubiquitous Comput. 2013, 13, 187-196. [CrossRef]

186. Gubbi, J.; Buyya, R.; Marusic, S.; Palaniswami, M. Internet of Things (IoT): A Vision, Architectural Elements, and Future Directions. Future Gener. Comput. Syst. 2013, 29, 1645-1660. [CrossRef]

187. Zhong, R.Y.; Li, Z.; Pang, L.Y.; Pan, Y.; Qu, T.; Huang, G.Q. RFID-Enabled Real-Time Advanced Planning and Scheduling Shell for Production Decision Making. Int. J. Comput. Integr. Manuf. 2013, 26, 649-662. [CrossRef]

188. Wu, D.-Z.; Greer, M.J.; Rosen, D.W.; Schaefer, D. Cloud Manufacturing: Strategic Vision and State-of-the-Art. J. Manuf. Syst. 2013, 32, 564-579. [CrossRef]

189. Moreno-Vozmediano, R.; Montero, R.S.; Llorente, I.M. Key Challenges in Cloud Computing: Enabling the Future Internet of Services. IEEE Internet Comput. 2013, 17, 18-25. [CrossRef]

190. Lee, J.; Kao, H.-A.; Yang, S. Service Innovation and Smart Analytics for Industry 4.0 and Big Data Environment. Proc. Cirp 2014, 16, 3-8. [CrossRef]

191. Bi, Z.; Xu, L.D.; Wang, C. Internet of Things for Enterprise Systems of Modern Manufacturing. IEEE Trans. Indust. Inf. 2014, 10, 1537-1546. [CrossRef]

192. Brettel, M.; Friederichsen, N.; Keller, M.; Rosenberg, M. How Virtualization, Decentralization, and Network-Building Change the Manufacturing Landscape: An Industry 4.0 Perspective. Int. J. Mech. Aerospac. Indust. Mechatron. Manuf. Eng. 2014, 8, 37-44.

193. Buer, S.-V.; Strandhagen, J.O.; Chan, F.T.S. The Link between Industry 4.0 and Lean Manufacturing: Mapping Current Research and Establishing a Research Agenda. Int. J. Prod. Res. 2018, 56, 2924-2940. [CrossRef]

194. Patel, P.; Cassou, D. Enabling High-Level Application Development for the Internet of Things. J. Syst. Softw. 2015, 103, 62-84. [CrossRef]

195. Zhang, Y.; Zhang, G.; Wang, J.; Sun, S.; Si, S.; Yang, T. Real-Time Information Capturing and Integration Framework of the Internet of Manufacturing Things. Int. J. Comput. Integr. Manuf. 2015, 28, 811-822. [CrossRef]

196. Qiu, X.; Luo, H.; Xu, G.; Zhong, R.-Y.; Huang, G.Q. Physical Assets and Service Sharing for IoT-Enabled Supply Hub in Industrial Park (SHIP). Int. J. Prod. Econ. 2015, 159, 4-15. [CrossRef]

197. Posada, J.; Toro, C.; Barandiaran, I.; Oyarzun, D.; Stricker, D.; de Amicis, R.; Pinto, E.B.; Eisert, P.; Döllner, J.; Vallarino, I. Visual Computing as a Key Enabling Technology for Industrie 4.0 and Industrial Internet. IEEE Comp. Graph. Appl. 2015, 35, 26-40. [CrossRef] [PubMed]

198. Farooq, M.U.; Waseem, M.; Mazhar, S.; Khairi, A.; Kamal, T. A Review on Internet of Things (IoT). Int. J. Comp. Appl. 2015, 113, 1-7. [CrossRef]

199. Lee, J.; Bagheri, B.; Kao, H.-A. A Cyber-Physical Systems Architecture for Industry 4.0-Based Manufacturing Systems. Manuf. Lett. 2015, 3, 18-23. [CrossRef] 
200. Almada-Lobo, F. The Industry 4.0 Revolution and the Future of Manufacturing Execution Systems (MES). J. Innov. Manag. 2015, 3, 16-21. [CrossRef]

201. Wamba, S.F.; Akter, S.; Edwards, A.; Chopin, G.; Gnanzou, D. How ‘Big Data' Can Make Big Impact: Findings from a Systematic Review and a Longitudinal Case Study. Int. J. Prod. Econ. 2015, 165, 234-246. [CrossRef]

202. Yin, Y.H.; Nee, A.Y.C.; Ong, S.K.; Zhu, J.Y.; Gu, P.H.; Chen, L.J. Automating Design with Intelligent Human-Machine Integration. Cirp Ann. 2015, 64, 655-677. [CrossRef]

203. Colin, M.; Galindo, R.; Hernández, O. Information and Communication Technology as a Key Strategy for Efficient Supply Chain Management in Manufacturing SMEs. Proc. Comp. Sci. 2015, 55, 833-842. [CrossRef]

204. Hozdic, E. Smart Factory for Industry 4.0: A Review. Int. J. Mod. Manuf. Tech. 2015, 7, 28-35.

205. Zhong, R.Y.; Huang, G.Q.; Lan, S.; Dai, Q.Y.; Zhang, T.; Xu, C. A Two-Level Advanced Production Planning and Scheduling Model for RFID-Enabled Ubiquitous Manufacturing. Adv. Eng. Inf. 2015, 29, 799-812. [CrossRef]

206. Wang, S.; Wan, J.; Zhang, D.; Li, D.; Zhang, C. Towards Smart Factory for Industry 4.0: A Self-Organized Multi-Agent System with Big Data Based Feedback and Coordination. Comp. Netw. 2016, 101, 158-168. [CrossRef]

207. Monostori, L.; Kádár, B.; Bauernhansl, T.; Kondoh, S.; Kumara, S.; Reinhart, G.; Sauer, O.; Schuh, G.; Sihn, W.; Ueda, K. Cyber-Physical Systems in Manufacturing. Cirp. Ann. 2016, 65, 621-641. [CrossRef]

208. Zhong, R.Y.; Lan, S.; Xu, C.; Dai, Q.; Huang, G.Q. Visualization of RFID-Enabled Shopfloor Logistics Big Data in Cloud Manufacturing. Int. J. Adv. Manuf. Technol. 2016, 84, 5-16. [CrossRef]

209. Georgakopoulos, D.; Jayaraman, P.P.; Fazia, M.; Villari, M.; Ranjan, R. Internet of Things and Edge Cloud Computing Roadmap for Manufacturing. IEEE Cloud Comp. 2016, 3, 66-73. [CrossRef]

210. Zhong, R.Y.; Newman, S.T.; Huang, G.Q.; Lan, S. Big Data for Supply Chain Management in the Service and Manufacturing Sectors: Challenges, Opportunities, and Future Perspectives. Comp. Indust. Eng. 2016, 101, 572-591. [CrossRef]

211. Misra, G.; Kumar, V.; Agarwal, A.; Agarwal, K. Internet of Things (IoT)—A Technological Analysis and Survey on Vision, Concepts, Challenges, Innovation Directions, Technologies, and Applications (An Upcoming or Future Generation Computer Communication System Technology). Am. J. Electr. Electro. Eng. 2016, 4, 23-32. [CrossRef]

212. Schumacher, A.; Erol, S.; Sihn, W. A Maturity Model for Assessing Industry 4.0 Readiness and Maturity of Manufacturing Enterprises. Proc. Cirp 2016, 52, 161-166. [CrossRef]

213. Sipsas, K.; Alexopoulos, K.; Xanthakis, V.; Chryssolouris, G. Collaborative Maintenance in Flow-Line Manufacturing Environments: An Industry 4.0 Approach. Proc. Cirp 2016, 55, 236-241. [CrossRef]

214. Qin, J.; Liu, Y.; Grosvenor, R. A Categorical Framework of Manufacturing for Industry 4.0 and Beyond. Proc. Cirp 2016, 52, 173-178. [CrossRef]

215. Referenzarchitekturmodell Industrie 4.0 (RAMI4.0); DIN SPEC 91345:2016-04; Beuth Verlag: Berlin, Germany, 2016.

216. Dobrzański, L.A. Comparative Analysis of Mechanical Properties of Scaffolds Sintered from Ti and Ti6Al4V Powders. In Proceedings of the Winter International Scientific Conference on Achievements in Mechanical and Materials Engineering, Zakopane, Poland, 6-9 December 2015.

217. Adolphs, P.; Auer, S.; Bedenbender, H.; Billmann, M.; Hankel, M.; Heidel, R.; Hoffmeister, M.; Huhle, H.; Jochem, M.; KieleDunsche, M.; et al. Structure of the Administration Shell: Continuation of the Development of the Reference Model. for the Industrie 4.0 Component; Federal Ministry for Economic Affairs and Energy: Berlin, Germany, 2016.

218. Bahrin, M.A.K.; Othman, M.F.; Azli, N.H.N.; Talib, M.F. Industry 4.0: A Review on Industrial Automation and Robotic. J. Tekno. 2016, 78, 137-143.

219. Mosterman, P.J.; Zander, J. Industry 4.0 as a Cyber-Physical System Study. Softw. Syst. Model. 2016, 15, 17-29. [CrossRef]

220. Harrison, R.; Vera, D.; Ahmad, B. Engineering Methods and Tools for Cyber-Physical Automation Systems. Proc. IEEE 2016, 104, 973-985. [CrossRef]

221. Stock, T.; Seliger, G. Opportunities of Sustainable Manufacturing in Industry 4.0. Proc. Cirp 2016, 40, 536-541. [CrossRef]

222. Pfeiffer, S. Robots, Industry 4.0 and Humans, or Why Assembly Work Is More than Routine Work. Societies 2016, 6, 16. [CrossRef]

223. Gorkhali, A.; Xu, L.D. Enterprise Application Integration in Industrial Integration: A Literature Review. J. Indust. Integr. Manag. 2016, 1, 1650014. [CrossRef]

224. Zhong, R.Y.; Xu, X.; Klotz, E.; Newman, S.T. Intelligent Manufacturing in the Context of Industry 4.0: A Review. Engineering 2017, 3, 616-630. [CrossRef]

225. Thoben, K.-D.; Wiesner, S.; Wuest, T. 'Industrie 4.0' and Smart Manufacturing-A Review of Research Issues and Application Examples. Int. J. Autom. Techn. 2017, 11, 4-16. [CrossRef]

226. Xu, X. Machine Tool 4.0 for the New Era of Manufacturing. Int. J. Adv. Manuf. Techn. 2017, 92, 1893-1900. [CrossRef]

227. Li, B.-H.; Hou, B.-C.; Yu, W.-T.; Lu, X.-B.; Yang, C.-W. Applications of Artificial Intelligence in Intelligent Manufacturing: A Review. Front. Infor. Techn. Electro. Eng. 2017, 18, 86-96. [CrossRef]

228. Lu, Y. Industry 4.0: A Survey on Technologies, Applications and Open Research Issues. J. Indust. Infor. Integr. 2017, 6, 1-10. [CrossRef]

229. Vaidya, S.; Ambad, P.; Bhosle, S. Industry 4.0-A Glimpse. Proc. Manuf. 2018, 20, 233-238. [CrossRef]

230. Kumar, K.; Zindani, D.; Davim, J.P. Industry 4.0: Developments towards the Fourth Industrial Revolution; Springer Nature: Singapore, 2019. 
231. Łobaziewicz, M. Zarządzanie Inteligentnym Przedsiębiorstwem W Dobie Przemystu 4.0; Towarzystwo Naukowe Organizacji i Kierownictwa: Torun, Poland, 2019.

232. Ardito, L.; Petruzzelli, A.M.; Panniello, U.; Garavelli, A.C. Towards Industry 4.0: Mapping Digital Technologies for Supply Chain Management-Marketing Integration. Bus. Proc. Manag. J. 2019, 25, 323-346. [CrossRef]

233. Boston Consulting Group. Putting Industry 4.0 to Work. Available online: https://www.bcg.com/capabilities/manufacturing/ industry-4.0 (accessed on 1 March 2021).

234. Tietenberg, T.; Lewis, L. Environmental and Natural Resource Economics; Pearson Education: London, UK, 2003.

235. Dobrzański, L.A. Significance of Materials Science and Engineering for Advances in Design and Manufacturing Processes, Computer Integrated Manufacturing. In Advanced Design and Management; Skołud, B., Krenczyk, D., Eds.; WNT: Warsaw, Poland, 2003; pp. 128-140.

236. Dobrzański, L.A. The importance of the development of materials science and materials engineering to improve the quality of life of modern societies. Wisnyk Technol. Univ. PodillaKhmelnytskyUkr. 2003, I, 34-47.

237. Dobrzański, L.A. Heat Treatment as Fundamental Technological Process of Formation of Structure and Properties of Metals. In Proceedings of the 8th Seminar of the International Federation for Heat Treatment and Surface Engineering, Cavtat, Croatia, 12-14 Semptember 2001; International Federation for Heat Treatment and Surface Engineering: Winterthur, Switzerland, 2001; pp. 1-12.

238. Dobrzański, L.A. Significance of Materials Science for Advances in Products Design and Manufacturing; General Assembly of the International Academy for Production Engineering: Cracow, Poland, 2004.

239. Tay, S.I.; Lee, T.C.; Hamid, N.A.A.; Ahmad, A.N.A. An Overview of Industry 4.0: Definition, Components, and Government Initiatives. J. Adv. Res. Dyn. Control. Syst. 2018, 10, 1379-1387.

240. Dobrzański, L.A. Podstawy Metodologii Projektowania Materiałowego; Wydawnictwo Politechniki Ślaskiej: Gliwice, Poland, 2009.

241. Dobrzański, L.A. Significance of materials science for the future development of societies. J. Mater. Process. Technol. 2006, 175, 133-148. [CrossRef]

242. Dobrzański, L.A. Materiały Inżynierskie I Projektowanie Materiałowe. Podstawy Nauki O Materiałach I Metaloznawstwo, 2nd ed.; suppl. \& changed; WNT: Warsaw, Poland, 2006.

243. Al-Fadda, S.A.; Zarb, G.A.; Finer, Y.A. A comparison of the accuracy of fit of 2 methods for fabricating implant-prosthodontic frameworks. Int. J. Prosthodont. 2007, 20, 125-131. [PubMed]

244. Helmus, M.N. Overview of Biomedical Materials. Bullet 1991, 16, 33-38. [CrossRef]

245. Singh, P.; Kumar, P. An Overview of Biomedical Materials and Techniques for Better Functional Performance, Life, Sustainability and Biocompatibility of Orthopedic Implants. Indian J. Sci. Tech. 2018, 11, 1-7. [CrossRef]

246. Hin, T.S. (Ed.) Engineering Materials for Biomedical Applications; World Scientific: Singapore, 2004. [CrossRef]

247. Wang, X. Overview on Biocompatibilities of Implantable Biomaterials. In Advances in Biomaterials Science and Biomedical Applications; Pignatello, R., Ed.; IntechOpen: Rijeka, Croatia, 2013. [CrossRef]

248. Pignatello, R. (Ed.) Advances in Biomaterials Science and Biomedical Applications; IntechOpen: Rijeka, Croatia, 2013.

249. Bronzino, J.D.; Peterson, D.R. The Biomedical Engineering Handbook, Volume 1: Biomedical Engineering Fundamentals. Physiologic Systems. Biomechanics. Biomaterials. Bioelectric Phenomena. Neuroengineering, 4th ed.; CRC Press: Boca Raton, FL, USA, 2019.

250. Bronzino, J.D.; Peterson, D.R. The Biomedical Engineering Handbook, Volume 2: Medical Devices and Systems. Biomedical Sensors. Medical Instrumentation and Devices. Human Performance Engineering. Rehabilitation Engineering. Clinical Engineering, 4th ed.; CRC Press: Boca Raton, FL, USA, 2019.

251. Bronzino, J.D.; Peterson, D.R. The Biomedical Engineering Handbook, Volume 3: Biomedical Signals, Imaging and Informatics. Biosignal Processing. Medical Imaging. Infrared Imaging. Medical Informatics, 4th ed.; CRC Press: Boca Raton, FL, USA, 2019.

252. Bronzino, J.D.; Peterson, D.R. The Biomedical Engineering Handbook, Volume 4: Molecular, Cellular and Tissue Engineering. Molecular Biology. Transport. Phenomena and Biomimetic Systems. Physiological Modeling, Simulation and Control. Stem Cell Engineering; An. Introduction. Tissue Engineering. Artificial Organs. Drug Design, Delivery Systems and Devices. Personalized Medicine. Ethics, 4th ed.; CRC Press: Boca Raton, FL, USA, 2019.

253. Kokubo, T. (Ed.) Biocermics and Their Clinical Applications; Woodhead Publishing: Cambridge, England, 2008 ; pp. 1-784.

254. Curtis, R.V.; Watson, T.F. (Eds.) Dental Biomaterials; Woodhead Publishing: Cambridge, UK, 2008; pp. 1-528.

255. Jenkins, M. (Ed.) Biomedical Polymers; Woodhead Publishing: Cambridge, UK, 2007; pp. 1-236.

256. Wiliams, D.F. (Ed.) Definitions in Biomaterials; Elsevier: Amsterdam, The Netherlands, 1987.

257. Dobrzański, L.A. Metaloznawstwo Opisowe; Wydawnictwo Politechniki Ślaskiej: Gliwice, Poland, 2013.

258. Wang, S.; Qu, X.; Zhao, R.C. Clinical applications of mesenchymal stem cells. J. Hematol. Oncol. 2012, 5, 1-9. [CrossRef] [PubMed]

259. Heness, G.; Ben-Nissan, B. Innovative bioceramics. Mater. Forum. 2004, 27, 104-114.

260. Parida, P.; Behera, A.; Mishra, S.C. Classification of Biomaterials used in Medicine. Int. J. Adv. Appl. Sci. 2012, 1, 31-35. [CrossRef]

261. Bronzino, J.D.; Peterson, D.R. The Biomedical Engineering Handbook, 4th ed.; CRC Press: Boca Raton, FL, USA, 2019.

262. Ratner, B.D.; Hoffman, A.S.; Schoen, F.J.; Lemons, J.E. (Eds.) Biomaterials Science: An. Introduction to Materials in Medicine, 3rd ed.; Academic Press: Oxford, UK, 2013.

263. Helmus, M.N.; Gibbons, D.F.; Cebon, D. Biocompatibility: Meeting a key functional requirement of next-generation medical devices. Toxicol. Pathol. 2008, 36, 70-80. [CrossRef] [PubMed]

264. Parida, P.; Mishra, S.C. Biomaterials in Medicine. Proceedings of the UGC Sponsored National Workshop on Innovative Experiments in Physics; Neelashaila Mahabidyalaya: Rourkela, India, 2012. 
265. Pramanik, S.; Agarwal, A.K.; Rai, K.N. Chronology of Total Hip Joint Replacement and Materials Development. Trends Biomater. Artif. Organs. 2005, 19, 15-26.

266. Chakrabarty, G.V. Biomaterials: Metallic Implant. Materials, Technology, Review Essays. IJAAS 2011, 1, 125-129.

267. Srivastav, A. An Overview of Metallic Biomaterials for Bone Support and Replacement. In Biomedical Engineering, Trends in Materials Science; Laskovski, A., Ed.; IntechOpen: Rijeka, Croatia, 2011; pp. 153-168. [CrossRef]

268. Yoo, Y.R.; Cho, H.H.; Jang, S.G.; Lee, K.Y.; Son, H.Y.; Kim, J.G.; Kim, Y.S. Effect of Co Content on The Corrosion of High Performance Stainless Steels In Simulated Bio-solutions. Key Eng. Mater. 2007, 342-343, 585-588. [CrossRef]

269. Billotte, W.G. Ceramic biomaterials. In The Biomedical Engineering Handbook, 2nd ed.; Bronzino, J.D., Ed.; CRC Press: Boca Raton, FL, USA, 2000; Volume 1, pp. 1-33.

270. Atala, A.; Lanza, R.; Nerem, R.; Thomson, J. Principles of Regenerative Medicine; Academic Press: Cambridge, MA, USA, 2007; pp. $1-1472$.

271. Lee, H.B.; Khang, G.; Lee, J.H. Polymeric Biomaterials. In Biomaterials; CRC Press: Boca Raton, FL, USA, 2007; pp. 55-78. [CrossRef]

272. Ehrlich, H. Biological Materials of Marine Origin; Springer: Dordrecht, The Netherlands, 2014. [CrossRef]

273. Jockisch, K.A.; Brown, S.A.; Bauer, T.W.; Merritt, K. Biological response to chopped-carbon-fiber-reinforced peek. J. Biomed. Mater. Res. 1992, 26, 133-146. [CrossRef]

274. Bos, R.R.; Rozema, F.R.; Boering, G.; Nijenhuis, A.J.; Pennings, A.J.; Jansen, H.W. Bone-plates and screws of bioabsorbable poly (L-lactide)—An animal pilot study. Br. J. Oral Maxillofac. Surg. 1989, 27, 467-476. [CrossRef]

275. Albertsson, A.C.; Varma, I.K. Aliphatic Polyesters: Synthesis, Properties and Applications. In Degradable Aliphatic Polyesters. Advances in Polymer Science; Albertsson, A.-C., Ed.; Springer: Berlin/Heidelberg, Germany, 2002; Volume 157, pp. 1-40. [CrossRef]

276. Zhu, S.L.; Wang, X.M.; Qin, F.X.; Inoue, A. A new Ti-based bulk glassy alloy with potential for biomedical application. Mater. Sci. Eng. A 2007, 459, 233-237. [CrossRef]

277. Zhang, E.; Yin, D.; Xu, L.; Yang, L.; Yang, K. Microstructure, mechanical and corrosion properties and biocompatibility of Mg-Zn-Mn alloys for biomedical application. Mater. Sci. Eng. C 2009, 29, 987-993. [CrossRef]

278. Li, S.J.; Niinomi, M.; Akahori, T.; Kasuga, T.; Yang, R.; Hao, Y.L. Fatigue characteristics of bioactive glass-ceramic-coated Ti-29Nb-13Ta-4.6Zr for biomedical application. Biomaterials 2004, 25, 3369-3378. [CrossRef]

279. Rajendran, V.; Bhandari, S.K. Bioactive Glasses for Implant Applications. Available online: https://www.drdo.gov.in/ monograph/bioactive-glasses-implant-applications (accessed on 1 March 2021).

280. Black, J. The education of the biomaterialist: Report of a survey, 1980-1981. J. Biomed. Mater. Res. 1982, 16, 159-167. [CrossRef] [PubMed]

281. Dobrzańska-Danikiewicz, A.D.; Łukowiec, D.; Cichocki, D.; Wolany, W. Nanokompozyty złożone z nanorurek węglowych pokrytych Nanokryształami Metali Szlachetnych. In Open Access Library V(2); Dobrzański, L.A., Ed.; International OCSCO World Press: Gliwice, Poland, 2015; pp. 1-131.

282. Qiu, G.; Ding, W. Editorial for the Special Issue on Medical Additive Manufacturing. Engineering 2020, 6, 1205-1206. [CrossRef]

283. Qiu, G.; Ding, W.; Tian, W.; Qin, L.; Zhao, Y.; Zhang, L.; Lu, J.; Chen, D.; Yuan, G.; Wu, C.; et al. Medical Additive Manufacturing: From a Frontier Technology to the Research and Development of Products. Engineering 2020, 6, 1217-1221. [CrossRef]

284. Wang, X.; Zhang, M.; Ma, J.; Xu, M.; Chang, J.; Gelinsky, M.; Wu, C. 3D Printing of Cell-Container-Like Scaffolds for Multicell Tissue Engineering. Engineering 2020, 6, 1276-1284. [CrossRef]

285. Wang, Y.; Tan, Q.; Pu, F.; Boone, D.; Zhang, M. A Review of the Application of Additive Manufacturing in Prosthetic and Orthotic Clinics from a Biomechanical Perspective. Engineering 2020, 6, 1258-1266. [CrossRef]

286. Liu, G.; He, Y.; Liu, P.; Chen, Z.; Chen, X.; Wan, L.; Li, Y.; Lu, J. Development of Bioimplants with 2D, 3D, and 4D Additive Manufacturing Materials. Engineering 2020, 6, 1232-1243. [CrossRef]

287. Li, C.; Pisignano, D.; Zhao, Y.; Xue, J. Advances in Medical Applications of Additive Manufacturing. Engineering 2020, 6, 1222-1231. [CrossRef]

288. Wang, Y.; Fu, P.; Wang, N.; Peng, L.; Kang, B.; Zeng, H.; Yuan, G.; Ding, W. Challenges and Solutions for the Additive Manufacturing of Biodegradable Magnesium Implants. Engineering 2020, 6, 1267-1275. [CrossRef]

289. Dobrzański, L.A.; Dobrzańska-Danikiewicz, A.D.; Czuba, Z.P.; Dobrzański, L.B.; Achtelik-Franczak, A.; Malara, P.; Szindler, M.; Kroll, L. The new generation of the biological-engineering materials for applications in medical and dental implant-scaffolds. Arch. Mater. Sci. Eng. 2018, 91, 56-85. [CrossRef]

290. Dobrzański, L.A.; Dobrzańska-Danikiewicz, A.D.; Czuba, Z.P.; Dobrzański, L.B.; Achtelik-Franczak, A.; Malara, P.; Szindler, M.; Kroll, L. Metallic skeletons as reinforcement of new composite materials applied in orthopaedics and dentistry. Arch. Mater. Sci. Eng. 2018, 92, 53-85. [CrossRef]

291. Dobrzański, L.B.; Achtelik-Franczak, A.; Dobrzańska, J.; Dobrzański, L.A. Comparison of the Structure and Properties of the Solid Co-Cr-W-Mo-Si Alloys Used for Dental Restorations CNC Machined or Selective Laser-Sintered. Mater. Perform. Charact 2020, 9, 556-578. [CrossRef]

292. Dobrzański, L.A.; Dobrzański, L.B.; Dobrzańska-Danikiewicz, A.D. Manufacturing technologies thick-layer coatings on various substrates and manufacturing gradient materials using powders of metals, their alloys and ceramics. J. Achiev. Mater. Manuf. Eng. 2020, 99, 14-41. [CrossRef] 
293. Dobrzański, L.A.; Dobrzański, L.B.; Dobrzańska-Danikiewicz, A.D. Additive and hybrid technologies for products manufacturing using powders of metals, their alloys and ceramics. Arch. Mater. Sci. Eng. 2020, 102, 59-85. [CrossRef]

294. Liao, B.; Xia, R.F.; Li, W.; Lu, D.; Jin, Z.M. 3D-Printed Ti6Al4V Scaffolds with Graded Triply Periodic Minimal Surface Structure for Bone Tissue Engineering. J. Mater. Eng. Perform. 2021. [CrossRef]

295. Xiong, Y.-Z.; Gao, R.-N.; Zhang, H.; Dong, L.-L.; Li, J.-T.; Li, X. Rationally designed functionally graded porous Ti6Al4V scaffolds with high strength and toughness built via selective laser melting for load-bearing orthopedic applications. J. Mech. Behav. Biomed. Mater. 2020, 104, 103673. [CrossRef] [PubMed]

296. Tripathi, Y.; Shukla, M.; Bhatt, A.D. Implicit-Function-Based Design and Additive Manufacturing of Triply Periodic Minimal Surfaces Scaffolds for Bone Tissue Engineering. J. Mater. Eng. Perform. 2019, 28, 7445-7451. [CrossRef]

297. Kelly, C.N.; Francovich, J.; Julmi, S.; Safranski, D.; Guldberg, R.E.; Maier, H.J.; Gall, K. Fatigue behavior of As-built selective laser melted titanium scaffolds with sheet-based gyroid microarchitecture for bone tissue engineering. Acta Biomater. 2019, 94, 610-626. [CrossRef]

298. Ma, S.; Tang, Q.; Feng, Q.; Song, J.; Han, X.; Guo, F. Mechanical behaviours and mass transport properties of bone-mimicking scaffolds consisted of gyroid structures manufactured using selective laser melting. J. Mech. Behav. Biomed. Mater. 2019, 93, 158-169. [CrossRef] [PubMed]

299. Yadroitsava, I.; du Plessis, A.; Yadroitsev, I. Bone regeneration on implants of titanium alloys produced by laser powder bed fusion: A review. In Titanium for Consumer Applications; Froes, F., Qian, M., Niinomi, M., Eds.; Elsevier: Amsterdam, The Netherlands, 2019; pp. 197-233. [CrossRef]

300. Zhang, L.; Yang, G.; Johnson, B.N.; Jia, X. Three-dimensional (3D) printed scaffold and material selection for bone repair. Acta Biomater. 2019, 84, 16-33. [CrossRef]

301. Ataee, A.; Li, Y.; Fraser, D.; Song, G.; Wen, C. Anisotropic Ti-6Al-4V gyroid scaffolds manufactured by electron beam melting (EBM) for bone implant applications. Mater. Des. 2018, 137, 345-354. [CrossRef]

302. Surmeneva, M.A.; Surmenev, R.A.; Chudinova, E.A.; Koptioug, A.; Tkachev, M.S.; Gorodzha, S.N.; Rännar, L.-E. Fabrication of multiple-layered gradient cellular metal scaffold via electron beam melting for segmental bone reconstruction. Mater. Des. 2017, 133, 195-204. [CrossRef]

303. Fousová, M.; Vojtěch, D.; Kubásek, J.; Jablonská, E.; Fojt, J. Promising characteristics of gradient porosity Ti-6Al-4V alloy prepared by SLM process. J. Mech. Behav. Biomed. Mater. 2017, 69, 368-376. [CrossRef]

304. Zhao, S.; Li, S.J.; Hou, W.T.; Hao, Y.L.; Yang, R.; Misra, R.D.K. The influence of cell morphology on the compressive fatigue behavior of Ti-6Al-4V meshes fabricated by electron beam melting. J. Mech. Behav. Biomed. Mater. 2016, 59, 251-264. [CrossRef] [PubMed]

305. Arahira, T.; Maruta, M.; Matsuya, S.; Todo, M. Development and characterization of a novel porous $\beta$-TCP scaffold with a three-dimensional PLLA network structure for use in bone tissue engineering. Mater. Lett. 2015, 152, 148-150. [CrossRef]

306. Yan, C.; Hao, L.; Hussein, A.; Young, P. Ti-6Al-4V triply periodic minimal surface structures for bone implants fabricated via selective laser melting. J. Mech. Behav. Biomed. Mater. 2015, 51, 61-73. [CrossRef] [PubMed]

307. Ahmadi, S.M.; Yavari, S.A.; Wauthle, R.; Pouran, B.; Schrooten, J.; Weinans, H.; Zadpoor, A.A. Additively Manufactured Open-Cell Porous Biomaterials Made from Six Different Space-Filling Unit Cells: The Mechanical and Morphological Properties. Materials 2015, 8, 1871-1896. [CrossRef] [PubMed]

308. Cheng, A.; Humayun, A.; Cohen, D.J.; Boyan, B.D.; Schwartz, Z. Additively manufactured 3D porous Ti-6Al-4V constructs mimic trabecular bone structure and regulate osteoblast proliferation, differentiation and local factor production in a porosity and surface roughness dependent manner. Biofabrication 2014, 6, 045007. [CrossRef] [PubMed]

309. Scherer, M.R.J. Double-Gyroid-Structured Functional Materials. Synthesis and Applications; Springer: Cham, Switzerland, 2013. [CrossRef]

310. Yan, C.; Hao, L.; Hussein, A.; Young, P.; Raymont, D. Advanced lightweight 316L stainless steel cellular lattice structures fabricated via selective laser melting. Mater. Des. 2014, 55, 533-541. [CrossRef]

311. Vrancken, B.; Thijs, L.; Kruth, J.-P.; Van Humbeeck, J. Heat treatment of Ti6Al4V produced by Selective Laser Melting: Microstructure and mechanical properties. J. Alloys Compd. 2012, 541, 177-185. [CrossRef]

312. Zhang, L.C.; Klemm, D.; Eckert, J.; Hao, Y.L.; Sercombe, T.B. Manufacture by selective laser melting and mechanical behavior of a biomedical Ti-24Nb-4Zr-8Sn alloy. Scr. Mater. 2011, 65, 21-24. [CrossRef]

313. Thijs, L.; Verhaeghe, F.; Craeghs, T.; Van Humbeeck, J.; Kruth, J.-P. A study of the microstructural evolution during selective laser melting of Ti-6Al-4V. Acta Mater. 2010, 58, 3303-3312. [CrossRef]

314. Parthasarathy, J.; Starly, B.; Raman, S.; Christensen, A. Mechanical evaluation of porous titanium (Ti6Al4V) structures with electron beam melting (EBM). J. Mech. Behav. Biomed. Mater. 2010, 3, 249-259. [CrossRef] [PubMed]

315. German, R.M. Sintering Theory and Practice; John Wiley \& Sons: New York, NY, USA, 1996.

316. German, R.M. Powder Metallurgy Science; Metal Powder Industries Federation: Princeton, NJ, USA, 1984.

317. German, R.M. Injection Molding of Metals and Ceramics; Metal Powder Industries Federation: Princeton, NJ, USA, 1997.

318. German, R.M. Powder Injection Molding; Metal Powder Industries Federation: Princeton, NJ, USA, 1990.

319. Sun, S.; Brandt, M.; Easton, M. Powder bed fusion processes: An overview. In Laser Additive Manufacturing; Materials, Design, Technologies, and Applications; Brandt, M., Ed.; Woodhead Publishing: Cambridge, UK, 2017; pp. 55-77. [CrossRef] 
320. Sahasrabudhe, H.; Bose, S.; Bandyopadhyay, A. Laser-based additive manufacturing processes. In Advances in Laser Materials Processing; Lawrence, J., Ed.; Woodhead Publishing: Cambridge, UK, 2018; pp. 507-539. [CrossRef]

321. Huo, S.H.; Qian, M.; Schaffer, G.B.; Crossin, E. Aluminium powder metallurgy. In Fundamentals of Aluminium Metallurgy; Production, Processing and Applications; Lumley, R., Ed.; Woodhead Publishing Limited: Cambridge, UK, 2011 ; pp. 655-701. [CrossRef]

322. German, R.M. Phase diagrams in liquid phase sintering treatments. JOM 1986, 38, 26-29. [CrossRef]

323. Schaffer, G.B.; Sercombe, T.B.; Lumley, R.N. Liquid phase sintering of aluminium alloys. Mater. Chem. Phys. 2001, 67, 85-91. [CrossRef]

324. Kang, S.-J.L. Basis of Liquid Phase Sintering. In Sintering, Densification, Grain Growth and Microstructure; Lumley, R., Ed.; Butterworth-Heinemann: Amsterdam, The Netherlands, 2005; pp. 199-203. [CrossRef]

325. Kang, S.-J.L. Liquid phase sintering. In Sintering of Advanced Materials; Fang, Z.Z., Ed.; Woodhead Publishing Limited: Cambridge, UK, 2010; pp. 110-129. [CrossRef]

326. Lumley, R.N.; Schaffer, G.B. The effect of solubility and particle size on liquid phase sintering. Scr. Mater. 1996, 35, 589-595. [CrossRef]

327. Kim, K.-B.; Kim, W.-C.; Kim, H.-Y.; Kim, J.-H. An evaluation of marginal fit of three-unit fixed dental prostheses fabricated by direct metal laser sintering system. Dent. Mater. 2013, 29, e91-e96. [CrossRef] [PubMed]

328. Barro, Ó.; Arias-González, F.; Lusquiños, F.; Comesaña, R.; del Val, J.; Riveiro, A.; Badaoui, A.; Gómez-Baño, F.; Pou, J. Effect of four manufacturing techniques (casting, laser directed energy deposition, milling and selective laser melting) on microstructural, mechanical and electrochemical properties of co-CR dental alloys, before and after PFM firing process. Metals 2020, $10,1291$. [CrossRef]

329. Dobrzański, L.B. Porównanie metod przyrostowych i ubytkowych wytwarzania uzupełnień protetycznych układu stomatognatycznego. In Metalowe Materiaty Mikroporowate I Lite Do Zastosowań Medycznych I Stomatologicznych; Open Access Library, VII(1); Dobrzański, L.A., Dobrzańska-Danikiewicz, A.D., Eds.; International OCSCO World Press: Gliwice, Poland, 2017 ; pp. $434-499$.

330. Dobrzański, L.A.; Dobrzańska-Danikiewicz, A.D.; Malara, P.; Achtelik-Franczak, A.; Dobrzański, L.B.; Gaweł, T.G. ImplantoSkafold Lub Proteza Elementów Anatomicznych Układu Stomatognatycznego Oraz Twarzoczaszki. Patent nr PL229148, 9 January 2018.

331. Dobrzański, L.A.; Dobrzańska-Danikiewicz, A.D.; Malara, P.; Achtelik-Franczak, A.; Dobrzański, L.B.; Gaweł, T.G. ImplantoSkafold Kostny. Patent nr PL229149, 9 January 2018.

332. Dobrzański, L.A.; Dobrzańska-Danikiewicz, A.D.; Malara, P.; Dobrzański, L.B.; Achtelik-Franczak, A.; Kremzer, M. Sposób wytwarzania materiałów kompozytowych o mikroporowatej szkieletowej strukturze wzmocnienia. Patent nr PL236090, 16 December 2019.

333. Dobrzański, L.B.; Dobrzański, L.A.; Dobrzańska, J.; Achtelik-Franczak, A. Wysokorozwinięty Powierzchniowo Implant Stomatologiczny. Zgłoszenie patentowe P.434312, 15 June 2020.

334. Dobrzański, L.B.; Dobrzański, L.A.; Dobrzańska, J.; Achtelik-Franczak, A. Wysokorozwinięty Powierzchniowo Implant Kostny W Tym Twarzoczaszki. Zgłoszenie patentowe P.434314, 15 June 2020.

335. Dobrzańska, J. Analiza Szczelności Wypełnień Kanałów Korzeniowych. Ph.D. Thesis, Śląski Uniwersytet Medyczny, Wydział Lekarski z Oddziałem Lekarsko-Dentystycznym, Zabrze, Poland, 2012.

336. Dobrzańska, J.; Gołombek, K.; Dobrzański, L.B. Polymer materials used in endodontic treatment-In vitro testing. Arch. Mater. Sci. Eng. 2012, 58, 110-115.

337. Dobrzański, L.B.; Achtelik-Franczak, A.; Dobrzańska, J.; Pietrucha, P. Application of polymer impression masses for the obtaining of dental working models for the stereolithographic 3D printing. Arch. Mater. Sci. Eng. 2019, 95, 31-40. [CrossRef]

338. Dobrzański, L.B.; Malara, P. Metodologia komputerowo wspomaganego projektowania i wytwarzania stomatologicznych uzupełnień protetycznych z litych materiałów inżynierskich. In Metalowe Materiaty Mikroporowate I Lite Do Zastosowań Medycznych I Stomatologicznych; Open Access Library, VII(1); Dobrzański, L.A., Dobrzańska-Danikiewicz, A.D., Eds.; International OCSCO World Press: Gliwice, Poland, 2017; pp. 500-534.

339. Dobrzański, L.B.; Dobrzański, L.A.; Dobrzańska, J.; Achtelik-Franczak, A.; Rudziarczyk, K. Akcesorium Montażowe Implantu Stomatologicznego. Zgłoszenie patentowe P.434313, 15 June 2020.

340. Kaiser, L.R. The future of multihospital systems. Top. Health Care Financ. 1992, 18, 32-45. [PubMed]

341. Arsiwala, A.; Desai, P.; Patravale, V. Recent advances in micro/nanoscale biomedical implants. J. Control. Release 2014, 189, 25-45. [CrossRef]

342. Yang, F.; Williams, C.G.; Wang, D.A.; Lee, H.; Manson, P.N.; Elisseeff, J. The effect of incorporating RGD adhesive peptide in polyethylene glycol diacrylate hydrogel on osteogenesis of bone marrow stromal cells. Biomaterials 2005, 26, 5991-5998. [CrossRef]

343. US National Institutes of Health. Regenerative Medicine 2006. Available online: https://stemcells.nih.gov/sites/all/themes/ stemcells_theme/stemcell_includes/Regenerative_Medicine_2006.pdf (accessed on 1 March 2021).

344. Cogle, C.R.; Guthrie, S.M.; Sanders, R.C.; Allen, W.L.; Scott, E.W.; Petersen, B.E. An overview of stem cell research and regulatory issues. Mayo Clin. Proc. 2003, 78, 993-1003. [CrossRef]

345. Metallo, C.M.; Azarin, S.M.; Ji, L.; De Pablo, J.J.; Palecek, S.P. Engineering tissue from human embryonic stem cells. J. Cell Mol. Med. 2008, 12, 709-729. [CrossRef] [PubMed] 
346. Placzek, M.R.; Chung, I.M.; Macedo, H.M.; Ismail, S.; Mortera Blanco, T.; Lim, M.; Cha, J.M.; Fauzi, I.; Kang, Y.; Yeo, D.C.; et al. Stem cell bioprocessing: Fundamentals and principles. J. R Soc. Interface 2009, 6, 209-232. [CrossRef] [PubMed]

347. Langer, R.; Vacanti, J.P. Tissue engineering. Science 1993, 260, 920-926. [CrossRef]

348. Viola, J.; Lal, B.; Grad, O. The Emergence of Tissue Engineering as a Research Field. Available online: https://www.nsf.gov / pubs/2004/nsf0450/start.htm (accessed on 1 March 2021).

349. Fung, Y.C. A Proposal to the National Science Foundation for An Engineering Research Center at UCSD: Center for the Engineering of Living Tissues. UCSD \#865023; University of California: San Diego, CA, USA, 2001.

350. Lanza, R.P.; Langer, R.; Vacanti, J. (Eds.) Principles of Tissue Engineering; Academic Press: San Diego, CA, USA, 2000.

351. Atala, A.; Lanza, R.P. (Eds.) Methods of Tissue Engineering; Academic Press: San Diego, CA, USA, 2002.

352. MacArthur, B.D.; Oreffo, R.O. Bridging the gap. Nature 2005, 433, 19. [CrossRef] [PubMed]

353. Tavassoli, M.; Crosby, W.H. Transplantation of marrow to extramedullary sites. Science 1968, 161, 54-56. [CrossRef] [PubMed]

354. Caplan, A.I. Mesenchymal stem cells. J. Orthop. Res. 1991, 9, 641-650. [CrossRef]

355. Pittenger, M.F.; Mackay, A.M.; Beck, S.C.; Jaiswal, R.K.; Douglas, R.; Mosca, J.D.; Moorman, M.A.; Simonetti, D.W.; Craig, S.; Marshak, D.R. Multilineage potential of adult human mesenchymal stem cells. Science 1999, 284, 143-147. [CrossRef] [PubMed]

356. Culme-Seymour, E.J.; Davie, N.L.; Brindley, D.A.; Edwards-Parton, S.; Mason, C. A decade of cell therapy clinical trials (2000-2010). Regen Med. 2012, 7, 455-462. [CrossRef]

357. Trounson, A.; Thakar, R.G.; Lomax, G.; Gibbons, D. Clinical trials for stem cell therapies. BMC Med. 2011, 9, 52. [CrossRef] [PubMed]

358. Thomson, J.A.; Itskovitz-Eldor, J.; Shapiro, S.S.; Waknitz, M.A.; Swiergiel, J.J.; Marshall, V.S.; Jones, J.M. Embryonic stem cell lines derived from human blastocysts. Science 1998, 282, 1145-1147, Erratum in Science 1998, 282, 1827. [CrossRef] [PubMed]

359. Shamblott, M.J.; Axelman, J.; Wang, S.; Bugg, E.M.; Littlefield, J.W.; Donovan, P.J.; Blumenthal, P.D.; Huggins, G.R.; Gearhart, J.D. Derivation of pluripotent stem cells from cultured human primordial germ cells. Proc. Natl. Acad. Sci. USA 1998, 95, 13726-13731. [CrossRef] [PubMed]

360. Cetrulo, C.L., Jr. Cord-blood mesenchymal stem cells and tissue engineering. Stem. Cell Rev. 2006, 2, 163-168. [CrossRef] [PubMed]

361. Branch, M.J.; Hashmani, K.; Dhillon, P.; Jones, D.R.; Dua, H.S.; Hopkinson, A. Mesenchymal stem cells in the human corneal limbal stroma. Invest. Ophthalmol. Vis. Sci. 2012, 53, 5109-5116. [CrossRef] [PubMed]

362. Americord. What Differentiates This Fast-Growth Cord Blood Bank? Available online: https:/ /bioinformant.com/americordwhat-differentiates-this-fast-growth-company-within-the-cord-blood-marketplace/ (accessed on 1 March 2021).

363. Lee, E.H.; Hui, J.H. The potential of stem cells in orthopaedic surgery. J. Bone Jt. Surg. Br. 2006, 88, 841-851. [CrossRef] [PubMed]

364. Le Blanc, K.; Tammik, L.; Sundberg, B.; Haynesworth, S.E.; Ringdén, O. Mesenchymal stem cells inhibit and stimulate mixed lymphocyte cultures and mitogenic responses independently of the major histocompatibility complex. Scand. J. Immunol. 2003, 57, 11-20. [CrossRef] [PubMed]

365. Maitra, B.; Szekely, E.; Gjini, K.; Laughlin, M.J.; Dennis, J.; Haynesworth, S.E.; Koç, O.N. Human mesenchymal stem cells support unrelated donor hematopoietic stem cells and suppress T-cell activation. Bone Marrow Transpl. 2004, 33, 597-604. [CrossRef] [PubMed]

366. Aggarwal, S.; Pittenger, M.F. Human mesenchymal stem cells modulate allogeneic immune cell responses. Blood 2005, 105, 1815-1822. [CrossRef]

367. Raff, M. Adult stem cell plasticity: Fact or artifact? Annu. Rev. Cell Dev. Biol. 2003, 19, 1-22. [CrossRef]

368. Morrison, S.J.; Weissman, I.L. The long-term repopulating subset of hematopoietic stem cells is deterministic and isolatable by phenotype. Immunity 1994, 1, 661-673. [CrossRef]

369. Bajada, S.; Mazakova, I.; Richardson, J.B.; Ashammakhi, N. Updates on stem cells and their applications in regenerative medicine. J. Tissue Eng. Regen Med. 2008, 2, 169-183. [CrossRef] [PubMed]

370. Johal, K.S.; Lees, V.C.; Reid, A.J. Adipose-derived stem cells: Selecting for translational success. Regen Med. 2015, 10, 79-96. [CrossRef]

371. Helmlinger, G.; Yuan, F.; Dellian, M.; Jain, R.K. Interstitial pH and pO2 gradients in solid tumors in vivo: High-resolution measurements reveal a lack of correlation. Nat. Med. 1997, 3, 177-182. [CrossRef]

372. Folkman, J. Tumor Angiogenesis: Therapeutic Implications. N. Engl. J. Med. 1971, 285, 1182-1186. [CrossRef]

373. Mooney, D.J.; Organ, G.; Vacanti, J.P.; Langer, R. Design and fabrication of biodegradable polymer devices to engineer tubular tissues. Cell Transpl. 1994, 3, 203-210. [CrossRef] [PubMed]

374. Li, G.; Virdi, A.S.; Ashhurst, D.E.; Simpson, A.H.; Triffitt, J.T. Tissues formed during distraction osteogenesis in the rabbit are determined by the distraction rate: Localization of the cells that express the mRNAs and the distribution of types I and II collagens. Cell Biol. Int. 2000, 24, 25-33. [CrossRef]

375. Sanders, J.E.; Malcolm, S.G.; Bale, S.D.; Wang, Y.N.; Lamont, S. Prevascularization of a biomaterial using a chorioallontoic membrane. Microvasc. Res. 2002, 64, 174-178. [CrossRef]

376. Muschler, G.F.; Nakamoto, C.; Griffith, L.G. Engineering principles of clinical cell-based tissue engineering. J. Bone Jt. Surg. Am. 2004, 86, 1541-1558. [CrossRef] 
377. Wilson, C.E.; Dhert, W.J.A.; van Blitterswijk, C.A.; Verbout, A.J.; de Bruijn, J.D. Evaluating 3D bone tissue engineered constructs with different seeding densities using the alamarBlue ${ }^{\mathrm{TM}}$ assay and the effect on in vivo bone formation. J. Mater. Sci. Mater. Med. 2002, 13, 1265-1269. [CrossRef] [PubMed]

378. Kruyt, M.C.; de Bruijn, J.D.; Wilson, C.E.; Oner, F.C.; van Blitterswijk, C.A.; Verbout, A.J.; Dhert, W.J. Viable osteogenic cells are obligatory for tissue-engineered ectopic bone formation in goats. Tissue Eng. 2003, 9, 327-336. [CrossRef]

379. Peppas, N.A.; Langer, R. New challenges in biomaterials. Science 1994, 263, 1715-1720. [CrossRef] [PubMed]

380. Hubbell, J.A. Biomaterials in tissue engineering. Biotechnnology 1995, 13, 565-576. [CrossRef] [PubMed]

381. Hubbell, J.A. Bioactive biomaterials. Curr. Opin. Biotechnol. 1999, 10, 123-129. [CrossRef]

382. Healy, K.E.; Rezania, A.; Stile, R.A. Designing biomaterials to direct biological responses. Ann. N. Y Acad. Sci. 1999, 875, 24-35. [CrossRef] [PubMed]

383. Langer, R.; Tirrell, D.A. Designing materials for biology and medicine. Nature 2004, 428, 487-492. [CrossRef] [PubMed]

384. Lutolf, M.P.; Hubbell, J.A. Synthetic biomaterials as instructive extracellular microenvironments for morphogenesis in tissue engineering. Nat. Biotechnol. 2005, 23, 47-55. [CrossRef]

385. Elisseeff, J.; Ferran, A.; Hwang, S.; Varghese, S.; Zhang, Z. The role of biomaterials in stem cell differentiation: Applications in the musculoskeletal system. Stem. Cells Dev. 2006, 15, 295-303. [CrossRef] [PubMed]

386. Hwang, N.S.; Kim, M.S.; Sampattavanich, S.; Baek, J.H.; Zhang, Z.; Elisseeff, J. Effects of three-dimensional culture and growth factors on the chondrogenic differentiation of murine embryonic stem cells. Stem. Cells 2006, 24, 284-291. [CrossRef] [PubMed]

387. Yang, F.; Neeley, W.L.; Moore, M.J.; Karp, J.M.; Shukla, A.; Langer, R. Tissue Engineering: The Therapeutic Strategy of the Twenty-First Century. In Nanotechnology and Tissue Engineering: The Scaffold; Laurencin, C.T., Nair, L.S., Eds.; CRC Press Taylor \& Francis Group: Boca Raton, FL, USA, 2008; pp. 3-32.

388. Bettinger, C.J.; Borenstein, J.T.; Langer, R. Microfabrication Techniques in Scaffold Development. In Nanotechnology and Tissue Engineering: The Scaffold; Laurencin, C.T., Nair, L.S., Eds.; CRC Press Taylor \& Francis Group: Boca Raton, FL, USA, 2008; pp. 87-122.

389. Noga, M.; Pawlak, A.; Dybala, B.; Dabrowski, B.; Swieszkowski, W.; Lewandowska-Szumiel, M. Biological Evaluation of Porous Titanium Scaffolds (Ti-6Al-7Nb) with HAp/Ca-P Surface Seeded with Human Adipose Derived Stem Cells. In Proceedings of the E-MRS Fall Meeting, Warszawa, Poland, 16-20 September 2013.

390. Rouwkema, J.; Rivron, N.C.; van Blitterswijk, C.A. Vascularization in tissue engineering. Trends Biotechnol. 2008, $26,434-441$. [CrossRef]

391. Bramfeldt, H.; Sabra, G.; Centis, V.; Vermette, P. Scaffold vascularization: A challenge for threedimensional tissue engineering. Curr. Med. Chem. 2010, 17, 3944-3967. [CrossRef] [PubMed]

392. Jain, R.K.; Au, P.; Tam, J.; Duda, D.G.; Fukumura, D. Engineering vascularized tissue. Nat. Biotechnol. 2005, 23, 821-823. [CrossRef] [PubMed]

393. Bose, S.; Roy, M.; Bandyopadhyay, A. Recent advances in bone tissue engineering scaffolds. Trends Biotechnol. 2012, 30, 546-554. [CrossRef] [PubMed]

394. Biomaterials Market Size, Share \& Trends Analysis Report by Product (Natural, Metallic, Polymer), by Application (Cardiovascular, Orthopedics, Plastic Surgery), by Region, and Segment Forecasts, 2020-2027. Available online: https://www. grandviewresearch.com/industry-analysis/biomaterials-industry (accessed on 12 March 2021).

395. Dental Biomaterial Market-Forecasts from 2020 to 2025. Available online: https://www.researchandmarkets.com/reports/5125 071/dental-biomaterial-market-forecasts-from-2020\#rela0-4989738 (accessed on 12 March 2021).

396. Orthopedic Biomaterials Market Size, Share \& Trends Analysis Report by Material Type (Ceramics \& Bioactive Glasses, Polymers), by Application (Orthobiologics, Orthopedic Implants), by Region, and Segment Forecasts, 2019-2025. Available online: https: //www.grandviewresearch.com/industry-analysis/orthopedic-biomaterials-market (accessed on 12 March 2021).

397. Tissue Engineering Market Size, Share \& Trends Analysis Report by Application (Cord Blood \& Cell Banking, Cancer, GI \& Gynecology, Dental, Orthopedics, Musculoskeletal, \& Spine), by Region, and Segment Forecasts, 2020-2027. Available online: https:/ / www.grandviewresearch.com/industry-analysis/tissue-engineering-and-regeneration-industry (accessed on 12 March 2021).

398. Regenerative Medicine Market Size, Share \& Trends Analysis by Product (Primary Cell-based, Stem \& Progenitor Cellbased), by Therapeutic Category (Dermatology, Oncology) and Segment Forecasts, 2019-2025. Available online: https:// www.grandviewresearch.com/industry-analysis/regenerative-medicine-market (accessed on 12 March 2021).

399. Cell Therapy Market Size, Share \& Trends Analysis Report by Use-type (Research, Commercialized, Musculoskeletal Disorders), by Therapy Type (Autologous, Allogeneic), by Region, and Segment Forecasts, 2020-2027. Available online: https://www. grandviewresearch.com/industry-analysis/cell-therapy-market (accessed on 12 March 2021).

400. Major Orthopedic Joint Replacement Implants Market—By Type (Knee Replacement Implants and Hip Replacement Implants), by Geography, and By Region, Opportunities And Strategies-Global Forecast To 2022. Available online: https://www. thebusinessresearchcompany.com/report/major-orthopedic-joint-replacement-implants-market (accessed on 12 March 2021).

401. Illgen, R.; Bukowski, B.; Abiola, R.; Anderson, P.; Chughtai, M.; Khlopas, A.; Mont, M. Robotic-assisted total hip arthroplasty: Outcomes at minimum two year follow up. Surg. Technol. Int. 2017, 30, 365-372. 
402. Kayani, B.; Konan, S.; Tahmassebi, J.; Pietrzak, J.R.T.; Haddad, F.S. Robotic-arm assisted total knee arthroplasty is associated with improved early functional recovery and reduced time to hospital discharge compared with conventional jig-based total knee arthroplasty: A prospective cohort study. Bone Jt. J. 2018, 100, 930-937. [CrossRef] [PubMed]

403. Kleeblad, L.J.; Borus, T.; Coon, T.; Dounchis, J.; Nguyen, J.; Pearle, A. Midterm survivorship and patient satisfaction of robotic-arm assisted medial unicompartmental knee arthroplasty: A multicenter study. J. Arthroplast. 2018, 33, 1719-1726. [CrossRef]

404. Dretakis, K.; Igoumenou, V.G. Outcomes of robotic-arm-assisted medial unicompartmental knee arthroplasty: Minimum 3-year follow-up. Eur. J. Orthop. Surg. Traumatol. 2019, 29, 1305-1311. [CrossRef]

405. Nawabi, D.; Conditt, M.; Ranawat, A.; Dunbar, N.; Jones, J.; Banks, S.; Padgett, D. Haptically guided robotic technology in total hip arthroplasty: A cadaveric investigation. Proc. Inst. Mech. Eng. H 2013, 227, 302-309. [CrossRef]

406. Suarez-Ahedo, C.; Gui, C.; Martin, T.; Chandrasekaran, S.; Domb, B. Robotic arm assisted total hip arthoplasty results in smaller acetabular cup size in relation to the femoral head size: A Matched-Pair Controlled Study. Hip. Int. 2017, 27, 147-152. [CrossRef]

407. Kayani, B.; Konan, S.; Pietrzak, J.R.T.; Haddad, F.S. Iatrogenic Bone and Soft Tissue Trauma in Robotic-Arm Assisted Total Knee Arthroplasty Compared with Conventional Jig-Based Total Knee Arthroplasty: A Prospective Cohort Study and Validation of a New Classification System. J. Arthroplast. 2018, 33, 2496-2501. [CrossRef]

408. Hampp, E.; Chang, T.C.; Pearle, A. Robotic partial knee arthroplasty demonstrated greater bone preservation compared to robotic total knee arthroplasty. In Proceedings of the Annual Orthopaedic Research Society Meeting, Austin, TX, USA, 2-5 February 2019. [CrossRef]

409. Kayani, B.; Konan, S.; Tahmassebi, J.; Rowan, F.E.; Haddad, F.S. An assessment of early functional rehabilitation and hospital discharge in conventional versus robotic-arm assisted unicompartmental knee arthroplasty. Bone Jt. J. 2019, 101-B, 24-33. [CrossRef]

410. Bell, S.W.; Anthony, I.; Jones, B.; MacLean, A.; Rowe, P.; Blyth, M. Improved Accuracy of Component Positioning with RoboticAssisted Unicompartmental Knee Arthroplasty: Data from a Prospective, Randomized Controlled Study. J. Bone Jt. Surg. Am. 2016, 98, 627-635. [CrossRef] [PubMed]

411. Herry, Y.; Batailler, C.; Lording, T.; Servien, E.; Neyret, P.; Lustig, S. Improved joint-line restitution in unicompartmental knee arthroplasty using a robotic-assisted surgical technique. Int. Orthop. 2017, 41, 2265-2271. [CrossRef] [PubMed]

412. Batailler, C.; White, N.; Ranaldi, F.M.; Neyret, P.; Servien, E.; Lustig, S. Improved implant position and lower revision rate with robotic-assisted unicompartmental knee arthroplasty. Knee Surg. Sports Traumatol. Arthrosc. 2019, 27, 1232-1240. [CrossRef] [PubMed]

413. Jaramaz, B.; Nikou, C.; Casper, M.; Grosse, S.; Mitra, R. Accuracy validation of semi-active robotic application for patellofemoral arthroplasty. In Proceedings of the International Society for Computer Assisted Orthopaedic Surgery, Vancover, BC, Canada, 17-20 June 2015.

414. Jaramaz, B.; Mitra, R.; Nikou, C.; Kung, C. Technique and Accuracy Assessment of a Novel Image-Free Handheld Robot for knee Arthroplasty in Bi-Cruiciate Retaining Total Knee Replacement. In Proceedings of the CAOS 2018. The 18th Annual Meeting of the International Society for Computer Assisted Orthopaedic Surgery, Beijing, China, 6-9 June 2018; Tian, W., Baena, F.R.Y., Eds.; EasyChair: Oxford, UK, 2018; Volume 2, pp. 98-101.

415. Data on File Smith E Nephew. Sg2 Healthcare Intelligence: Technology Guide; Sg2: Skokie, IL, USA, 2014.

416. Gregori, A.; Picard, F.; Bellemans, J.; Smith, J.; Simone, A. Handheld precision sculpting tool for unicondylar knee arthroplasty. A clinical review. In Proceedings of the 15th EFORT Congress, London, UK, 4-6 June 2014.

417. Smith, J.R.; Picard, F.; Lonner, J.; Hamlin, B.; Rowe, P.; Riches, P.; Deakin, A. The accuracy of a robotically-controlled freehand sculpting tool for unicondylar knee arthroplasty. In Proceedings of the Congress of the International Society of Biomechanics, Natal, Brazil, 4-9 August 2013.

418. Gustke, K.; Golladay, G.; Roche, M.W.; Jerry, G.; Elson, L.C.; Anderson, C.R. Increased Patient Satisfaction After Total Knee replacement using sensor-guided technology. Bone Jt. J. 2014, 96, 1333-1338. [CrossRef] [PubMed]

419. Gregori, A.; Picard, F.; Lonner, J.; Smith, J.; Jaramaz, B. Accuracy of imageless robotically assisted unicondylar knee arthroplasty. In Proceedings of the International Society for Computer Assisted Orthopaedic Surgery, Vancover, BC, Canada, 17-20 June 2015.

420. 3D Printing in the Medical Industry: The 3D Printed Knee Replacement. Available online: https://www.sculpteo.com/blog/20 18/05/04/3d-printing-in-the-medical-industry-the-3d-printed-knee-replacement/ (accessed on 12 March 2021).

421. How 3D Printing and Modeling are Changing Joint Replacement Surgery. Available online: https://www.yalemedicine.org/ news/3d-joint-replacement (accessed on 12 March 2021).

422. Replacement Knee Surgery: 3D Printing . . . Science Fiction or Remarkable Reality? Available online: https://www. bennettorthosportsmed.com/replacement-knee-surgery-3d-printingscience-fiction-remarkable-reality/ (accessed on 12 March 2021).

423. Knee Replacement Using State-Of-The-Art 3D Printer Technology. Available online: https://www.fairfield.org.uk/kneereplacement-using-state-of-the-art-3d-printer-technology/ (accessed on 12 March 2021).

424. Hip Replacement Market Size, Share \& Industry Analysis, by Procedure (Total Hip Replacement, Partial Hip Replacement, and Revision \& Hip Resurfacing), by End User (Hospitals \& Ambulatory Surgery Centers, Orthopedic Clinics, and Others) and Regional Forecast, 2019-2026. Available online: https://www.fortunebusinessinsights.com/industry-reports/hip-replacementimplants-market-100247 (accessed on 12 March 2021). 
425. Hip Replacement Implants Market Size, Share, \& Trends Analysis Report by Product (Total Hip, Partial Femoral Head), By Application, (MOM, MOP, COP), By End Use (Orthopedic Clinics), By Region, And Segment Forecasts, 2019-2026. Available online: https:/ / www.grandviewresearch.com/industry-analysis/hip-replacement-implants-market (accessed on 12 March 2021).

426. Global Hip Replacement Implants Market Size, Market Share, Application Analysis, Regional Outlook, Growth Trends, Key Players, Competitive Strategies and Forecasts, 2018 to 2026. Available online: https: / / www.researchandmarkets.com/reports / 47 60571/global-hip-replacement-implants-market-size (accessed on 12 March 2021).

427. Hip Replacement Implants Market Growth Projection, Sales Statistics, Size Value, Latest Trends, Future Insights and Share Estimation by 2025. Available online: https://www.medgadget.com/2021/02/hip-replacement-implants-market-growthprojection-sales-statistics-size-value-latest-trends-future-insights-and-share-estimation-by-2025.html (accessed on 12 March 2021).

428. Conformis Announces the first 3D Total Hip Replacement Surgeries performed at JFK Medical Center in Florida. Available online: https:/ /www.globenewswire.com/news-release/2018/08/01/1545816/0/en/Conformis-Announces-the-first-3D-TotalHip-Replacement-Surgeries-performed-at-JFK-Medical-Center-in-Florida.html (accessed on 12 March 2021).

429. Sasazawa, F. Case Study: The Simple and Accurate Cup Setting with Portable Navigation System in Total Hip Arthroplasty. Available online: http:/ / www.orthalign.com/wp-content/uploads/2018/08/Case-STudy-2017_HipAlign_Sasazawa.pdf (accessed on 12 March 2021).

430. Durbhakula, S. Case Study: OrthAlign®Technology Was Imperative for This Patient with a Prior Spinal Fusion Undergoing Right THA. Available online: http://www.orthalign.com/wp-content/uploads/2018/04/HipAlign_case-study-durbhakula3.pdf (accessed on 12 March 2021).

431. Knee Replacement Implants Market Size, Share \& Analysis, by Procedure Type (Total Knee Replacement, Partial Knee Replacement, Revision Knee), by Material, by Component, by End Users (Clinic, Hospital, Ambulatory Service Centers), and Segment Forecasts to 2027. Available online: https:/ / www.reportsanddata.com/report-detail/knee-replacement-implants-market (accessed on 12 March 2021).

432. Knee Replacement Market Size, Share \& COVID-19 Impact Analysis, by Procedure (Total Knee Arthroplasty, Partial Knee Arthroplasty, and Revision Arthroplasty) by Implant Type (Fixed Bearing, Mobile Bearing, and Others) End-user (Hospitals, Orthopedic Clinics, Ambulatory Surgical Centers, and Others) and Regional Forecast, 2020-2027. Available online: https: //www.fortunebusinessinsights.com/industry-reports/knee-replacement-implants-market-101244 (accessed on 12 March 2021).

433. Knee Implants Market Forecast to 2027 - Covid-19 Impact and Global Analysis - by Procedure (Total Knee Replacement, Partial Knee Replacement and Revision Knee Replacement), Implant Type (Fixed Bearing Implant and Mobile Bearing Implant), Material (Stainless Steel, Cobalt \& Chromium Alloys, Titanium \& Titanium Alloys, Tantalum, Zirconium and Others) and By End User (Hospitals, Ambulatory Surgical Centers and Others). Available online: https:/ / www.theinsightpartners.com/reports/kneeimplants-market (accessed on 12 March 2021).

434. Global Knee Replacement Market Research Report: Information by Product Type (Total Knee Reconstructive Implants, Partial Knee Reconstructive Implants, Revision Knee Reconstructive Implants), Material (Metal Alloy, Ceramic Material, Strong Plastic Parts and Others), End User (Hospitals and Clinics, Specialty Centers, and Rehabilitation Centers), and Region (Americas, Europe, Asia-Pacific, and the Middle East \& Africa)—Forecast till 2025. Available online: https://www.marketresearchfuture.com/ reports / knee-replacement-market-1578 (accessed on 12 March 2021).

435. Aesculapius with His Sons Podalairius and Machaon and Three Daughters-With Supplicants. Greek Relief Found at Thyrea. at National Museum Athens. Available online: https://wellcomecollection.org/works/ekhkh79b (accessed on 12 March 2021).

436. Filippou, D.; Tsoucalas, G.; Panagouli, E.; Thomaidis, V.; Fiska, A. Machaon, Son of Asclepius, the Father of Surgery. Cureus 2020, 12, e7038. [CrossRef]

437. Oxilia, G.; Peresani, M.; Romandini, M.; Matteucci, C.; Debono Spiteri, C.; Henry, A.G.; Schulz, D.; Archer, W.; Crezzini, J.; Boschin, F.; et al. Earliest evidence of dental caries manipulation in the Late Upper Palaeolithic. Sci. Rep. 2015, 5, 12150. [CrossRef]

438. Oxyrhynchus Papyrus 2547. Available online: http://archives.wellcomelibrary.org/DServe/dserve.exe?dsqIni=Dserve.ini\& dsqApp=Archive\&dsqCmd=Show.tcl\&dsqDb=Catalog\&dsqPos=47\&dsqSearch=\%28Sources_guides_used $\% 3 \mathrm{D} \% 27 \mathrm{Near} \% 20$ and $\% 20$ Middle\%20East $\% 27 \% 29$ (accessed on 12 March 2021).

439. Barns, J.W.B. The Oxyrhynchus Papyri; Part 31; Cambridge University Press: London, UK, 1966; pp. $62-65$.

440. Nutton, V. Marie-Helene Marganne, Inventaire analytique des papyrus grecs de médecine, Geneva, Librairie Droz, 1981, 8vo, pp. x, 409. Med. Hist. 1983, 27, 97. [CrossRef]

441. Miranda, E.A. Mondino de Luzzi. Medical Terminology Dictionary; Clinical Anatomy Associates: Ohio. Available online: https: / clinicalanatomy.com/mtd/548 (accessed on 12 March 2021).

442. Nierzwicki, K. Warszawski egzemplarz De humani corporis fabrica Andreasa Vesaliusa (Bazylea 1555) ze zbiorów Biblioteki Narodowej. Przyczynek do dziejów recepcji anatomii wesaliańskiej w Polsce. Available online: https://repozytorium. umk.pl/bitstream/handle/item/3030/Warszawski\%20egzemplarz\%20A.\%20Vesaliusa\%20\%E2\%80\%94\%20ksi\%C4\%99ga\%20 jubileuszowa $\% 20 \% \mathrm{E} 2 \% 80 \% 94 \% 20 \mathrm{z} \% 20$ ilustracjami.pdf? sequence=1 (accessed on 12 March 2021).

443. Kleczek, K. De humani corporis fabrica libri septem. Najsłynniejsze XVI-wieczne dzieło o anatomii człowieka. Available online: https: / / kc-cieszyn.pl/de-humani-corporis-fabrica-libri-septem-najslynniejsze-xvi-wieczne-dzielo-o-anatomii-czlowieka / (accessed on 12 March 2021). 
444. Szkice Anatomiczne. Leonardo da Vinci. SERIA I. Available online: https://manuscriptum.pl/store/product/szkiceanatomiczne-leonardo-da-vinci-seria-i (accessed on 12 March 2021).

445. Landrus, M. The Treasures of Leonardo da Vinci: The Story of His Life \& Work; Andre Deutsch: London, UK, 2014.

446. Lugli, E. In cerca della perfezione: Nuovi elementi per l’Uomo vitruviano di Leonardo Da Vinci. In Leonardo e Vitruvio: Oltre Il Cerchio E Il Quadrato; Borgostr, F., Ed.; Marsilio Books: Venice, Italy, 2019; pp. 69-91.

447. Press Release: The Nobel Prize in Physiology or Medicine 2020. Available online: https://www.nobelprize.org/prizes/medicine/ 2020/press-release/ (accessed on 12 March 2021). 